$$
\begin{gathered}
\text { Aus der Abteilung Biochemie II } \\
\text { (ehem. Leiter: Prof. em. Dr. med. K. von Figura) }
\end{gathered}
$$

im Zentrum Biochemie und Molekulare Zellbiologie

der Medizinischen Fakultät der Universität Göttingen

\title{
Herstellung zweier Gene-Targeting-Vektoren \\ zur Generierung von Mausmodellen für CDG-la \\ mit den Mutationen F115L und R137H im PMM2-Gen
}

\section{INAUGURAL - DISSERTATION}

\author{
zur Erlangung des Doktorgrades \\ der Medizinischen Fakultät der \\ Georg-August-Universität zu Göttingen \\ vorgelegt von \\ $\underline{\text { Jan Rindermann }}$ \\ aus \\ Göttingen
}

Göttingen 2012 
Dekan:

I. Berichterstatter:

II. Berichterstatter/in:

III. Berichterstatter/in:
Prof. Dr. med. M. P. Schön

Prof. em. Dr. med. von Figura

Prof. Dr. Dr. med. Steinfeld

Prof. Dr. med., Dr. rer. nat. Crozier 


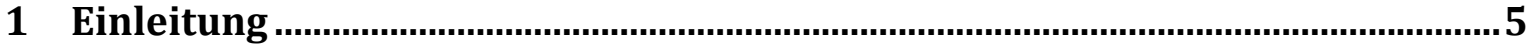

1.1 Glykosylierung von Proteinen

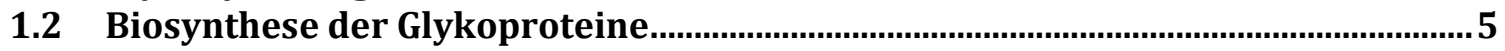

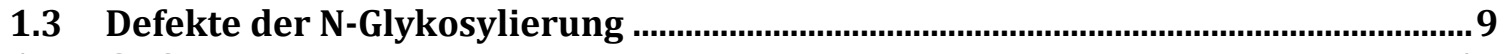

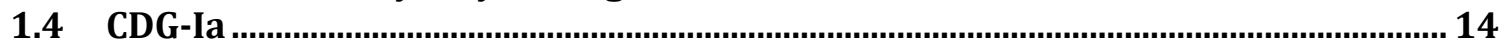

1.4.1 Klinische Präsentation der CDG-Ia-Patienten ............................................................. 14

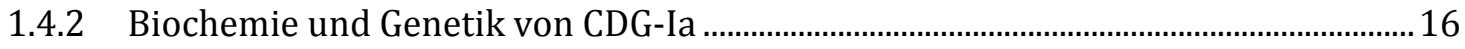

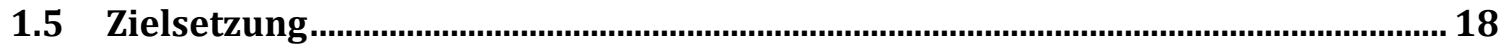

2 Material und Methoden ...................................................................................... 19

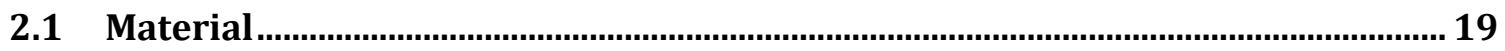

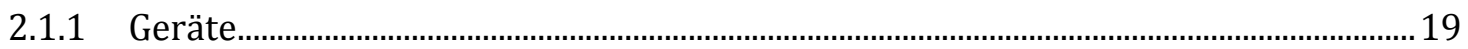

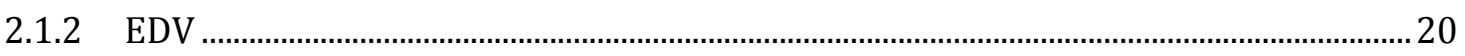

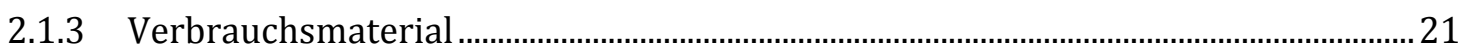

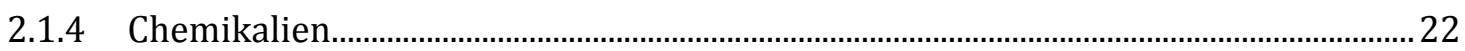

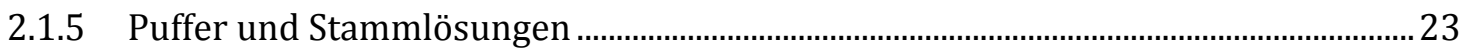

2.1.6 Medien zur Anzucht prokaryontischer Zellen ............................................................. 23

2.1.7 Zellkulturmedien, Medienzusätze und Lösungen zur Arbeit mit eukaryontischen

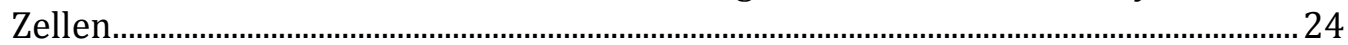

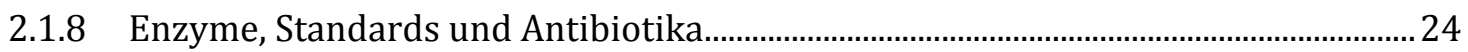

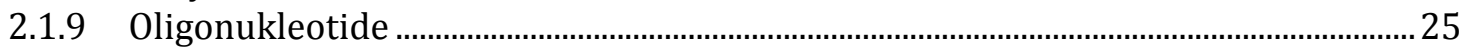

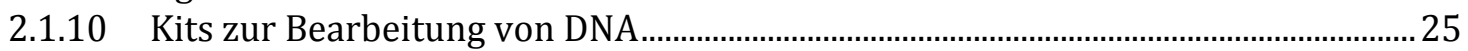

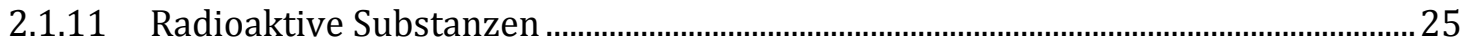

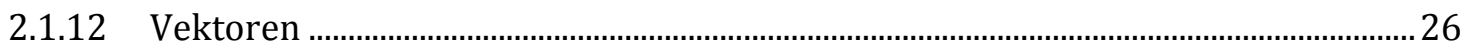

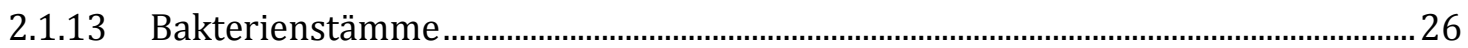

2.1.14 Embryonale Stammzellen.............................................................................................26

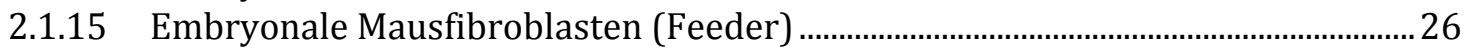

2.1.16 Mausstämme..........................................................................................................26

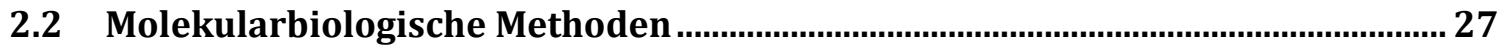

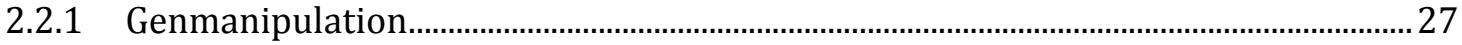

2.2.1.1 "gene targeting" durch homologe Rekombination in murinen ES-Zellen ..........................28

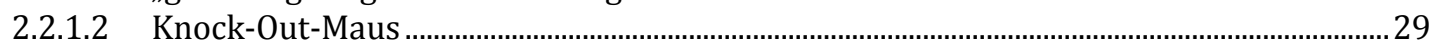

2.2.1.3 Hypomorphes Mausmodell..............................................................................................29

2.2.2 Standardbedingungen und -methoden der Molekularbiologie .....................................30

2.2.3 Konzentrationsbestimmung von Nukleinsäuren ............................................................ 30

2.2.4 Spaltung von DNA mit Restriktionsendonukleasen ....................................................... 31

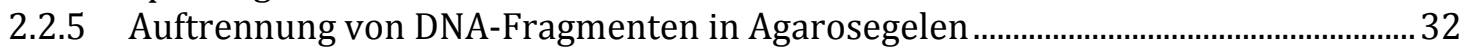

2.2.6 Isolierung von DNA-Fragmenten aus Agarosegelen ..........................................................

2.2.7 Ligation eines DNA-Fragmentes in einen Vektor .............................................................. 33

2.2.8 Amplifikation von Plasmid-DNA im Prokaryontensystem ..............................................34

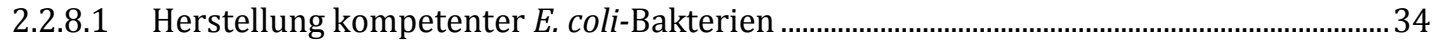

2.2.8.2 Transformation kompetenter E. coli-Bakterien mit Plasmid-DNA durch

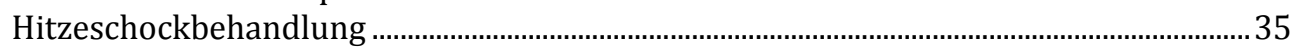

2.2.8.3 Mini-Präparation von Plasmid-DNA aus E. coli-Bakterien........................................................35

2.2.8.4 Midi-Präparation von Plasmid-DNA aus E. coli-Bakterien.......................................................36

2.2.9 Isolierung genomischer DNA aus embryonalen Stammzellen.......................................37

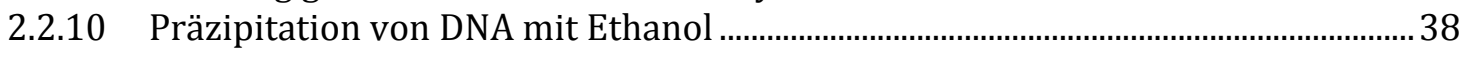

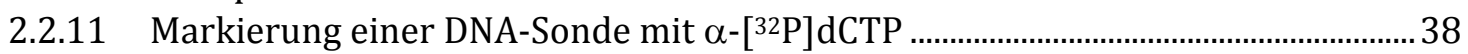

2.2.12 Transfer von DNA auf Hybond N-Filter (Southern-Blot)........................................... 38

2.2.13 Hybridisierung von Southern-Blots mit radioaktiv markierten Sonden ................. 40

2.2.14 Polymerase-Ketten-Reaktion ................................................................................. 41

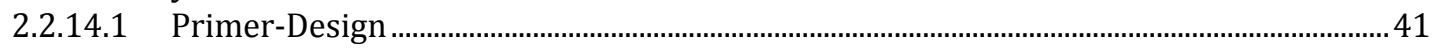

2.2.14.2 Standard-PCR ..................................................................................................................... 42

2.2.14.3 PCR mit dem AccuPrime ${ }^{\mathrm{TM}}$-Taq-DNA-Polymerase-System und dem HotStar-Taq-DNAPolymerase-System ............................................................................................................... 43 
2.2.14.4 In-vitro-Mutagenese mit dem QuikChange ${ }^{\mathrm{TM}}$ Site-Directed Mutagenesis Kit...................4 43

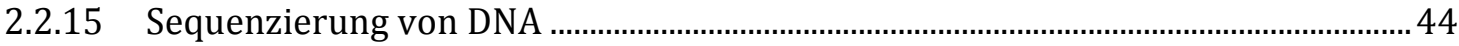

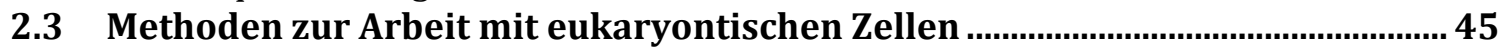

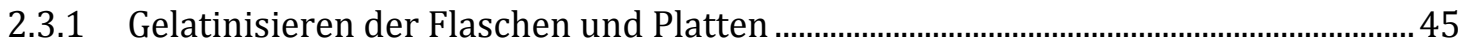

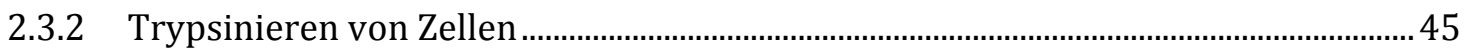

2.3.3 Präparation von primären Neo-resistenten Fibroblasten ............................................45

2.3.4 Mitotische Inaktivierung von Fibroblasten ........................................................................ 46

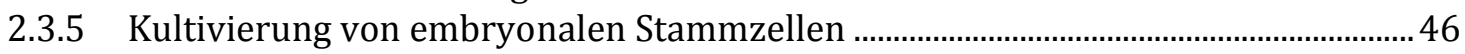

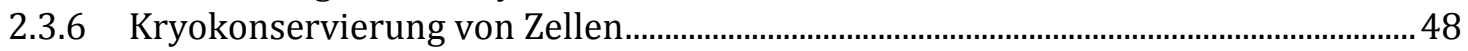

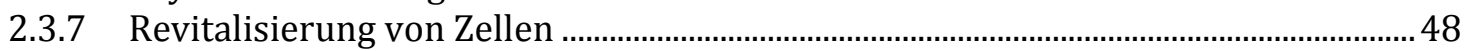

2.3.8 DNA-Transfer in ES-Zellen durch Elektroporation.......................................................... 48

2.3.9 Selektion von ES-Zell-Klonen nach Elektroporation................................................... 49

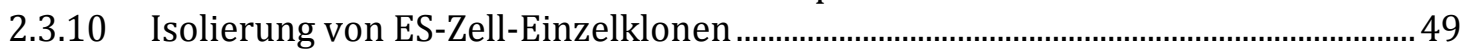

2.3.11 Ausschneiden der gefloxten Neo-Kassette .................................................................... 50

2.3.12 Vorbereitung von ES-Zellen für die Mikroinjektion .....................................................50

3 Ergebnisse ............................................................................................. 51

3.1 Generierung der Gene-Targeting-Vektoren (GTV) …............................................. 51

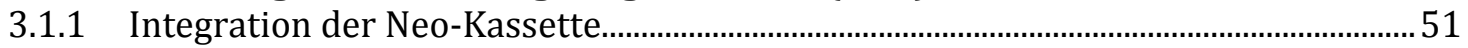

3.1.2 Einbringen der Mutation F115L bzw. R137H ………................................................ 55

3.1.3 Zusammenfügen der Fragmente für GTV-F115L und GTV-R137H.............................56

3.1.4 Vorbereitung der zwei GTV zur Elektroporation ………….........................................5

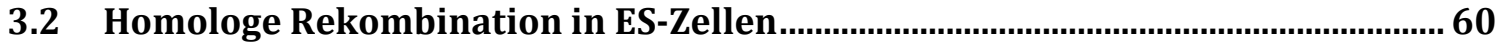

3.2.1 Elektroporation der ES-Zellen....................................................................................6

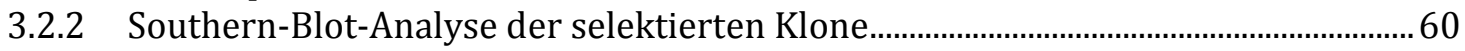

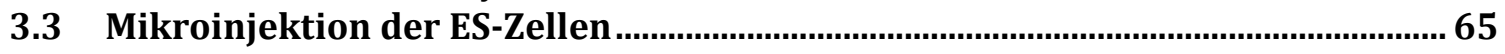

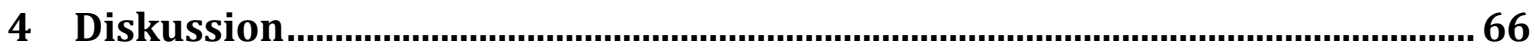

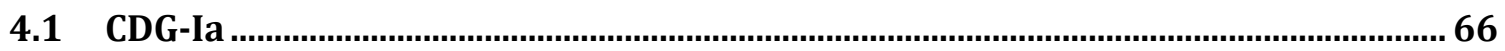

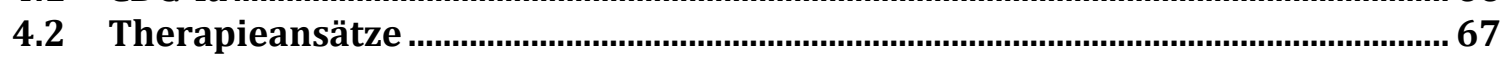

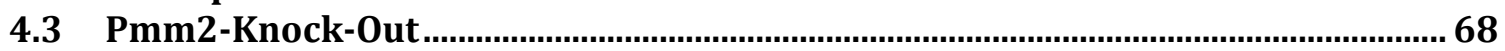

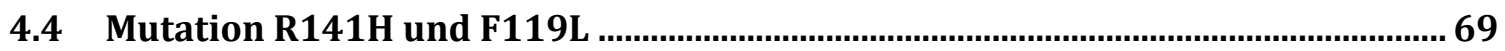

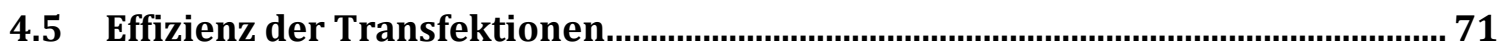

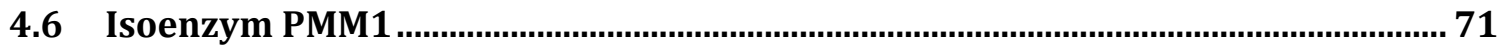

5 Zusammenfassung und Ausblick …………............................................................73

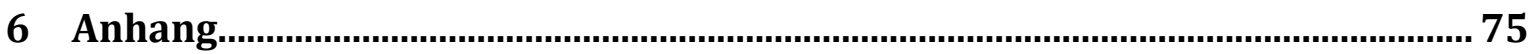

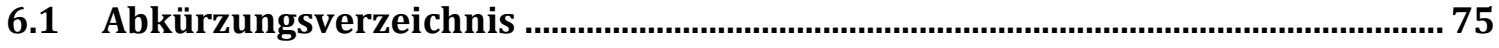

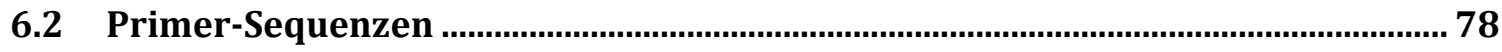

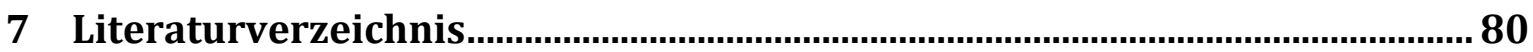




\section{$1 \quad$ Einleitung}

\section{$1.1 \quad$ Glykosylierung von Proteinen}

Neben Genom und Proteom nimmt das Glykom, die Gesamtheit der Zuckerstrukturen eines Organismus, eine immer wichtiger werdende Rolle im Verständnis der molekularen Biochemie ein. Je nach Spezies ist das Glykom 10 bis $10^{4}$ mal größer als das gesamte Proteom (Freeze, 2006).

Ein großer Teil dieser Zuckerstrukturen wird durch Glykoproteine gestellt. Die Glykosylierung von Proteinen stellt eine der häufigsten co- und posttranslationalen Proteinmodifikationen dar (Spiro, 1973). Glykoproteine kommen sowohl in eukaryontischen Zellen, als auch in Archaebakterien und Viren vor. Überwiegend handelt es sich um sezernierte Proteine und Membranproteine. Beispielhaft hierfür sind Immunglobuline, Transportmoleküle, Enzyme und Hormone. Viele komplexe Zell-Zell- und Zell-Matrix-Wechselwirkungen werden von glykosylierten Strukturproteinen wie Kollagen und Rezeptoren vermittelt. Dabei sind die Kohlenhydratseitenketten essentiell für die korrekte Faltung, Löslichkeit und Proteaseresistenz und damit für die biologische Aktivität der Proteine. Zudem sind sie mitverantwortlich für den intra- und interzellulären Transport von Proteinen (Varki, 1993). Ihre Relevanz zeigen Oligosaccharidseitenketten bei interzellulären Prozessen wie der Fertilisation (Gabius, 1987), der Embryogenese (Lennarz, 1993) und der Zelladhäsion. In den letzten Jahren hat das medizinische Interesse an der Proteinglykosylierung sowohl durch Beobachtungen der veränderten Glykan-Expression auf Krebszellen während des Vorgangs der Transformation (Fukuda, 1996) als auch durch Identifizierung immer neuer vererbter Glykosylierungsdefekte beim Menschen stark zugenommen.

\subsection{Biosynthese der Glykoproteine}

Die primären Schritte der Glykoproteinbiosynthese im ER stellen einen hoch konservierten Vorgang dar (Kornfeld und Kornfeld, 1985). Die Synthese beginnt mit der Bereitstellung Nukleotid-aktivierter Zucker im Zytosol. Die Synthesewege 
dieser Zucker sind eng miteinander verknüpft (Kean, 1991). Bis auf die CMPSialinsäure, die im Zellkern synthetisiert wird (Münster et al., 1998), werden die restlichen Zucker wie Z.B. GDP-Mannose (GDP-Man), GDP-Fucose, UDPGalaktose, UDP-Glukose (UDP-Glc) im Zytoplasma generiert. Zunächst wird UDPaktiviertes N-Acetylglukosamin auf ein phosphoryliertes Dolichol übertragen, welches als Lipid-Anker in der Membran des Endoplasmatischen Retikulums (ER) lokalisiert ist (Abb.:1). Diese UMP freisetzende Reaktion findet auf der zytosolischen Seite des ER mit Hilfe der UDP-GIcNAc:GIcNAc-1Phosphotransferase statt. Darauf wird ein zweiter N-Acetylglukosaminrest (GlcNAc) gebunden (Dol-P-P-GlcNAc 2 ). Nachfolgend werden schrittweise fünf Mannosereste vom Donor GDP-Mannose auf Dol-P-P-GIcNAc 2 übertragen, so dass ein biantennärer $\mathrm{Man}_{5}-\mathrm{GlcNAc}_{2}$-P-P-Dol-Komplex entsteht. Die weitere Assemblierung des Oligosaccharides geschieht innerhalb des ER. Eine sogenannte "Flippase" (Rft1) überführt das Intermediat in das Lumen des ER (Helenius et al., 2002). Vier weitere Mannose- und drei Glukosereste werden nun nacheinander durch spezifische Mannosyl- und Glukosyltransferasen auf das lipidverknüpfte Oligosaccharid bis zur vollständigen Struktur Dol-P-P$\mathrm{GlCNAc}_{2} \mathrm{Man}_{9} \mathrm{Glc}_{3}$ übertragen. Die Mannosereste werden dazu zuvor im Zytoplasma von GDP-Mannose auf Dolichol-Phosphat transferiert und an diesem Lipidcarrier (LEC35 protein) ins Lumen des ER transportiert. Die Glukosereste gelangen über einen vergleichbaren Mechanismus in das Lumen, nachdem sie von UDP-Glukose auf Dolichol-Phosphat übertragen worden sind (Hirschberg et al., 1998; Anand et al., 2001).

Im Anschluss erfolgt die cotranslationale covalente Übertragung des vollständigen $\mathrm{GlCNAc}_{2} \mathrm{Man}_{9} \mathrm{Gl}_{3}$-Oligosaccharids unter Freisetzung von Dolicholpyrophosphat auf ein naszierendes Protein. Dieser Schritt wird durch einen Oligosaccharyltransferase-Komplex katalysiert, der die Amidgruppen von AsnResten in der Konsensus-Sequenz Asn-X-Ser/Thr (wobei X jede beliebige Aminosäure außer Pro und Asp repräsentiert) als unmittelbaren Akzeptor nutzt.

Noch im Lumen des ERs setzen sogenannte „Trimming“-Schritte durch die Glukosidasen I und II ein, die die drei terminalen Glukosereste abspalten und Teile der Protein-Qualitätskontrolle sind. Die korrekte Faltung des Glykoproteins wird durch ein Wechselspiel zwischen der UDP-Glukose-Glykoproteintransferase und dem ER-ständigen membrangebundenen Chaperon Calnexin mit seinem löslichen 
Homologon Calreticulin sowie der all-Glukosyltransferase kontrolliert (Tatu und Helenius, 1997). Eine $\alpha$-Mannosidase entfernt einen ersten Man-Rest des Glykoproteins, bevor es als Dol-P-P-GIcNAc $-\mathrm{Man}_{8}$ vesikulär zum Golgi weiter transportiert wird. Im Golgi folgen weitere Strukturveränderungen. Andere $\alpha-$ Mannosidasen verkürzen das Oligosaccharid zum Man ${ }_{5}-\mathrm{GlcNAc}_{2}$-Rest.

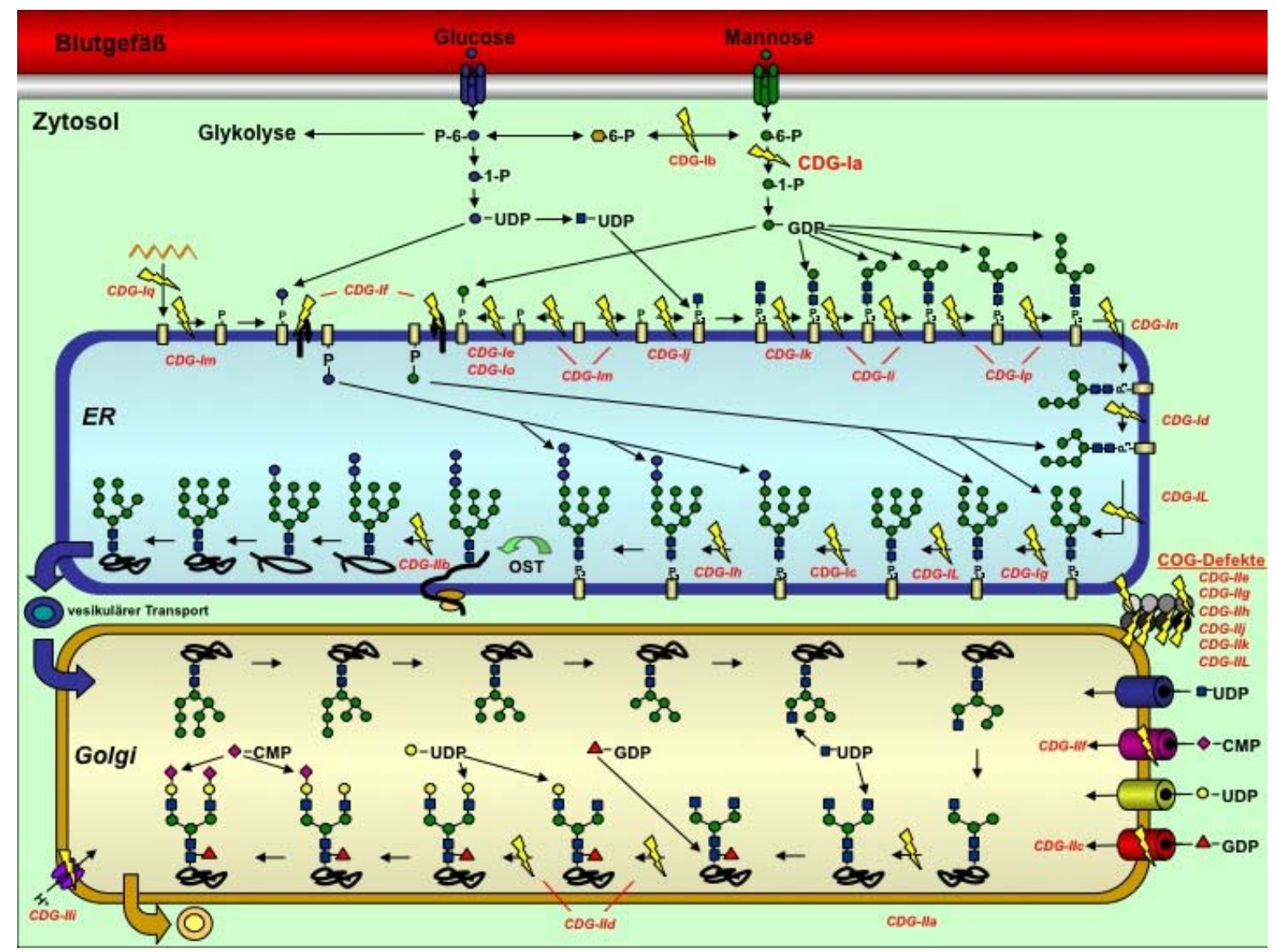

$\begin{array}{rlrl}\square & =\text { Dolichol } & 0 & =\text { Galaktose } \\ \square & =\text { N-Acetylglucosamin } & \diamond & =\text { Sialinsäure } \\ \square & =\text { Mannosen } & \Delta= & =\text { Fucose } \\ \ominus & =\text { Glukose } & \Delta=\text { Congenital Disorders of Glycosylation }(\mathrm{CDG})\end{array}$

Abb. 1: Biosynthese der Glykoproteine mit Darstellung der bislang entdeckten Glykosylierungsdefekte CDG-la bis -lq und CDG-Ila bis -IIL (mit freundlicher Genehmigung von Prof. Körner, Heidelberg, www.klinikum.uni-heidelberg.de/1-DieGlykoproteinbiosynthese.9504.0.html). 
Im Golgi wird dann anhand weiterer Trimming und Elongationsschritte, die durch die Aminosäuresequenz des jeweiligen Glykoproteins vorgegeben sind, entschieden, ob das synthetisierte Oligosaccharid später dem komplexen, hybriden oder mannosereichen Typ zugeordnet wird (Abb.: 2).

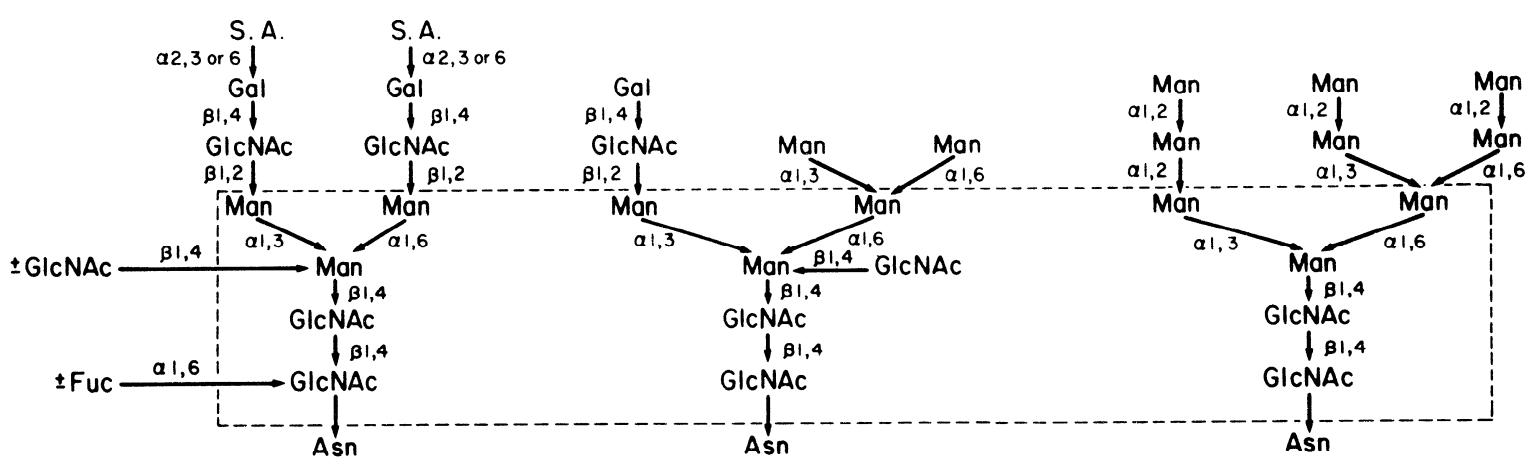

Abb. 2: Dargestellt sind die drei Typen der synthetisierten Oligosaccharide. Der komplexe, der hybride und der mannosereiche Typ. Gemeinsam ist den drei Typen die Kernregion in der gestrichelten Fläche.

Allen $\mathrm{N}$-glykosidischen verknüpften Oligosaccharidseitenketten gleich ist die Kernregion $\mathrm{GlcNAc}_{2} \mathrm{Man}_{3}$. Am häufigsten findet sich bei Vertebraten extrazellulär das N-Glykan vom komplexen Typ. Durch spezifische Glykosyltransferasen werden im medialen und trans-Golgi-Komplex die für jedes Protein typischen peripheren Saccharidreste wie drei N-Acetylglukosamin-, drei Galaktose-, einen Fucose- oder auch drei Sialinsäurereste übertragen. Es entstehen Oligosaccharide mit großer Diversität in Bezug auf die einzelnen Saccharidreste, als auch in der Anzahl der Verzweigungen des Oligosaccharides (Kornfeld und Kornfeld, 1985).

Zusammenfassend kann der Prozess der N-Glykosylierung in drei Schritte unterteilt werden; die Synthese des lipidverknüpften Oligosaccharides $\mathrm{GlcNAc}_{2}{ }^{-}$ $\mathrm{Man}_{9} \mathrm{Glc}_{3}$ im ER, die cotranslationale Übertragung auf Asparaginreste eines Proteins und die Modifikation des Glykoproteins im Golgi. 


\subsection{Defekte der N-Glykosylierung}

Defekte der Glykoproteinbiosynthese sind erst seit kurzem bekannt (Jaeken et al., 1980, 1984), obwohl über 300 verschiedene Glykosyltransferasen, Glykosidasen und Transportproteine an dem komplexen Vorgang der Glykoproteinbiosynthese beteiligt sind und über $1 \%$ des menschlichen Genoms diese Proteine kodieren (Freeze, 1998). Der belgische Kinderarzt Jaak Jaeken bezeichnete diese Erkrankung, die er bei einem eineiigen Zwillingspaar mit psychomotorischen Retardierungen beobachtet hatte, zunächst als "Carbohydrate Deficient Glykoprotein Syndrom" (CDGS) (Jaeken et al., 1980). Die biochemische Ursache war inm noch nicht bekannt und wurde erst 15 Jahre später aufgeklärt (van Schaftingen und Jaeken, 1995). Inzwischen wurde eine Vielzahl genetischer Defekte in der Glykoproteinbiosynthese identifiziert und auch Defekte anderer Glykokonjugate wie z.B. Glykolipide wurden bereits beschrieben. Auf dem „First International Workshop on CDGS" (Leuven, Belgien, 12./13. November 1999) wurde deshalb eine Umbenennung der Krankheitsgruppe von CDGS in das allgemeinere "Congenital Disorders of Glycosylation“ (CDG) beschlossen (Aebi et al., 1999). Dabei werden diese autosomal rezessiv vererbten Defekte je nach Lokalisation in zwei Gruppen unterteilt: In der Gruppe I werden alle Defekte eingeordnet, welche die Synthese der dolicholverknüpften Oligosaccharide einschließlich inres Transfers auf das neusynthetisierte Protein betreffen, und in der Gruppe II alle Erkrankungen, deren Ursache Fehler in den nachfolgenden Modifikationen des Glykoproteins darstellen. In der zeitlichen Reihenfolge der Aufklärung ihrer molekularen Ursachen erfolgt die Untergruppierung durch kleine Buchstaben. 
Tab. 1: Aktuelle Liste veröffentlichter CDG-Typen identifizierter Patienten. ( ${ }^{*} \mathrm{OMIM}=$ online Mendelian inheritance in man)

\begin{tabular}{|c|c|c|c|c|c|}
\hline $\begin{array}{l}\text { CDG- } \\
\text { Typ }\end{array}$ & $\begin{array}{l}\text { betroffenes } \\
\text { Gen }\end{array}$ & |Enzym & Referenz & *OMIM & $\begin{array}{l}\text { Anzahl } \\
\text { bisher } \\
\text { bekannter } \\
\text { Fälle }\end{array}$ \\
\hline la & PMM2 & Phosphomannomutase II & $\begin{array}{l}\text { van } \\
\text { Schaftingen } \\
\text { und Jaeken, } \\
1995\end{array}$ & 212065 & $>700$ \\
\hline$\overline{l b}$ & $P M I$ & $\begin{array}{l}\text { Phosphomannose } \\
\text { Isomerase }\end{array}$ & $\begin{array}{l}\text { Niehues et } \\
\text { al., } 1998\end{array}$ & 602579 & $\geq 20$ \\
\hline Ic & $h A L G 6$ & $\begin{array}{l}\text { Dol-P-Glc:Man }{ }_{9} \mathrm{GlcNAc}_{2}-\mathrm{P}- \\
\text { P-Dol- } \alpha-1,3- \\
\text { Glukosyltransferase }\end{array}$ & $\begin{array}{l}\text { Körner et al., } \\
\text { 1998; Burda } \\
\text { et al., 1998; } \\
\text { Imbach et } \\
\text { al., } 1999\end{array}$ & 603147 & $\geq 30$ \\
\hline Id & $h A L G 3$ & $\begin{array}{l}\text { Dol-P-Man:Man }{ }_{5} \mathrm{GlcNAc}_{2}- \\
\text { P-P-Dol- } \alpha-1,3- \\
\text { Mannosyltrasferase }\end{array}$ & $\begin{array}{l}\text { Körner et al., } \\
1999\end{array}$ & 601110 & $\geq 8$ \\
\hline le & DPM1 & Dol-P-Man-Synthase I & $\begin{array}{l}\text { Kim et al., } \\
2000 ; \\
\text { Imbach et } \\
\text { al., } 2000\end{array}$ & 603503 & $\geq 7$ \\
\hline If & MPDU1 & $\begin{array}{l}\text { Man-P-Dol- } \\
\text { utilisation1/Lec35 }\end{array}$ & $\begin{array}{l}\text { Kranz et al., } \\
2001 ; \\
\text { Schenk et } \\
\text { al., } 2001\end{array}$ & 609180 & $\geq 5$ \\
\hline Ig & hALG12 & $\begin{array}{l}\text { Dol-P-Man:Man }{ }_{7} \mathrm{GlcNAc}_{2-} \\
\text { P-P-Dol- } \alpha-6- \\
\text { Mannosyltransferase }\end{array}$ & $\begin{array}{l}\text { Thiel et al., } \\
2002 ; \\
\text { Chantret et } \\
\text { al., 2002; } \\
\text { Grubenmann }\end{array}$ & 607143 & $\geq 7$ \\
\hline
\end{tabular}




\begin{tabular}{|c|c|c|c|c|c|}
\hline & & & et al., 2002 & & \\
\hline Ih & $h A / g 8$ & $\begin{array}{l}\text { Dol-P- } \\
\text { Glc:GlcMan }{ }_{9} \mathrm{GlcNAc}_{2}-\mathrm{P}-\mathrm{P}- \\
\text { Dol- } \alpha-3- \\
\text { Glukosyltransferase }\end{array}$ & $\begin{array}{l}\text { Chantret et } \\
\text { al., 2003; } \\
\text { Schollen et } \\
\text { al., } 2004\end{array}$ & 608104 & $\geq 4$ \\
\hline Ii & $h A L G 2$ & $\begin{array}{l}\text { GDP-Man: ManGlcNAc } 2 \text {-P- } \\
\text { P-Dol-Mannosyltransferase }\end{array}$ & $\begin{array}{l}\text { Thiel et al., } \\
2003\end{array}$ & 607906 & $\geq 1$ \\
\hline Ij & DPAGT1 & $\begin{array}{l}\text { UDP-GlcNAc-Dol-P-N- } \\
\text { Acetylglukosamin }\end{array}$ & $\begin{array}{l}\text { Wu et al., } \\
2003\end{array}$ & 608093 & $\geq 1$ \\
\hline $\mathbf{I k}$ & $A L G 1$ & $\begin{array}{l}\text { Beta-1,4- } \\
\text { Mannosyltransferase }\end{array}$ & $\begin{array}{l}\text { Schwarz et } \\
\text { al., 2004; } \\
\text { Kranz et al., } \\
2004\end{array}$ & 608540 & $\geq 4$ \\
\hline II & $A L G 9$ & $\begin{array}{l}\text { Mannosyltransferase Dol- } \\
\text { P-Man: } \text { Man }_{6-} \text { und Man } \\
\text { G- }^{-} \\
\text {GlucNAc2-P-P-Dol- } \\
\text { Mannosyltransferase }\end{array}$ & $\begin{array}{l}\text { Frank et al., } \\
2004 ; \\
\text { Weinstein et } \\
\text { al., } 2005\end{array}$ & 608776 & $\geq 2$ \\
\hline & TMEM15 & Dolichol-Kinase & $\begin{array}{l}\text { Kranz et al., } \\
2007 a\end{array}$ & 610768 & $\geq 4$ \\
\hline \multirow[t]{2}{*}{ In } & RFT1 & $\begin{array}{l}\text { Man }_{5} \mathrm{GlcNAc}_{2} \text {-PP-Dol- } \\
\text { Flippase }\end{array}$ & $\begin{array}{l}\text { Haeuptle et } \\
\text { al., } 2008\end{array}$ & 612015 & $\geq 1$ \\
\hline & DPM3 & $\begin{array}{l}\text { Dolichol-Phosphat- } \\
\text { Mannosyltransferase } \\
\text { subunit } 3\end{array}$ & $\begin{array}{l}\text { Lefeber et } \\
\text { al., } 2009\end{array}$ & 612937 & $\geq 1$ \\
\hline Ip & ALG11 & $\begin{array}{l}\text { GDP-Man:Man3GIcNAc2- } \\
\text { PP-dolichol-alpha1,2- } \\
\text { Mannosyltransferase }\end{array}$ & $\begin{array}{l}\text { Rind et al., } \\
2010\end{array}$ & 613666 & $\geq 2$ \\
\hline Iq & SRD5A3 & $\begin{array}{l}\text { Steroid-5alpha-Reduktase } \\
\text { Typ } 3\end{array}$ & $\begin{array}{l}\text { Cantagrel et } \\
\text { al., } 2010 .\end{array}$ & 612379 & $\geq 19$ \\
\hline Ila & MGAT2 & GlcNAc-Transferase 2 & $\begin{array}{l}\text { Jaeken et } \\
\text { al., 1994; } \\
\text { Tan et al., } \\
1996\end{array}$ & 212066 & $\geq 3$ \\
\hline
\end{tabular}




\begin{tabular}{|c|c|c|c|c|c|}
\hline Illb & GCS1 & $\alpha-1,2-G l u k o s i d a s e ~ \mid$ & $\left|\begin{array}{l}\text { de Praeter et } \\
\text { al., } 2000\end{array}\right|$ & 606056 & $\mid \geq 1$ \\
\hline IIC & FUCT1 & GDP-Fucose-Transporter & $\begin{array}{l}\text { Lübke et al., } \\
\text { 1999; Lübke } \\
\text { et al., 2001; } \\
\text { Lühn et al., } \\
2001\end{array}$ & 266265 & $\geq 5$ \\
\hline Ild & $B 4 G A L T 1$ & $\begin{array}{l}\text { UDP-Gal:GIcNAc- } \beta-1,4- \\
\text { Galaktosyltransferase I }\end{array}$ & $\begin{array}{l}\text { Hansske et } \\
\text { al., 2002; } \\
\text { Peters et al., } \\
2002 ;\end{array}$ & 607091 & $\geq 1$ \\
\hline Ile & COG7 & $\begin{array}{l}\text { Conserved oligomeric golgi } \\
\text { complex subunit } 7\end{array}$ & $\begin{array}{l}\text { Wu et al., } \\
2004\end{array}$ & 608779 & $\geq 8$ \\
\hline IIf & SLC35A1 & CMP-sialic acid transporter & $\begin{array}{l}\text { Willig et al., } \\
2001 ; \\
\text { Martinez- } \\
\text { Duncker et } \\
\text { al., } 2005\end{array}$ & 603585 & $\geq 1$ \\
\hline$\overline{l l g}$ & COG1 & $\begin{array}{l}\text { Conserved oligomeric golgi } \\
\text { complex subunit } 1\end{array}$ & $\begin{array}{l}\text { Foulquier et } \\
\text { al., } 2006\end{array}$ & 611209 & $\geq 3$ \\
\hline IIh & COG8 & $\begin{array}{l}\text { Conserved oligomeric golgi } \\
\text { complex subunit } 8\end{array}$ & $\begin{array}{l}\text { Foulquier et } \\
\text { al., 2007; } \\
\text { Kranz et al., } \\
2007 b\end{array}$ & 611182 & $\geq 2$ \\
\hline III & COG5 & $\begin{array}{l}\text { Conserved oligomeric golgi } \\
\text { complex subunit } 5\end{array}$ & \begin{tabular}{|l} 
Paesold- \\
Burda et al., \\
2009
\end{tabular} & 613612 & $\geq 1$ \\
\hline$\overline{\mathrm{Ilj}}$ & COG4 & $\begin{array}{l}\text { Conserved oligomeric golgi } \\
\text { complex subunit } 4\end{array}$ & $\begin{array}{l}\text { Reynders et } \\
\text { al., } 2009\end{array}$ & 613489 & $\geq 3$ \\
\hline$\overline{\text { III }}$ & COG6 & $\begin{array}{l}\text { Conserved oligomeric golgi } \\
\text { complex subunit } 6\end{array}$ & $\begin{array}{l}\text { Lübbehusen } \\
\text { et al., } 2010\end{array}$ & & $\geq 1$ \\
\hline
\end{tabular}


Da Glykoproteine an sehr vielen wichtigen biologischen Prozessen beteiligt sind, äußern sich Störungen in ihrer Biosynthese zumeist multisystemisch. Übergreifend auf alle Subtypen des CDG-Syndroms leiden die meisten Patienten unter schweren Entwicklungsstörungen, psychomotorischen Retardierungen, Muskelhypotonie, Hirnatrophien und Krampfanfällen. 1987 beschrieben Jaeken et al. neben dem für CDG-Patienten typischen Phänotyp auch die verminderte Anzahl der Glykoproteine und die fehlenden Sialinsäure-, Galaktose- und NAcetylglukosaminreste in Serum-Glykoproteinen. Verdachtspatienten werden routinemäßig auf veränderte Glyko-Strukturen ihres Serum-Transferrins hin untersucht. Transferrin ist ein in der Leber gebildetes Plasmaprotein, welches freies Eisen bindet und transportiert. Es trägt an den Asparaginresten 413 und 611 zwei biantennäre sialylierte Oligosaccharide vom komplexen Typ (Spik et al. 1975). Die jeweiligen Sialinsäurereste sind an ihrem Ende negativ geladen, so dass Transferrin in seiner Tetrasialoform vier negative Ladungen trägt (MacGillivray et al., 1983) (Abb.: 3).

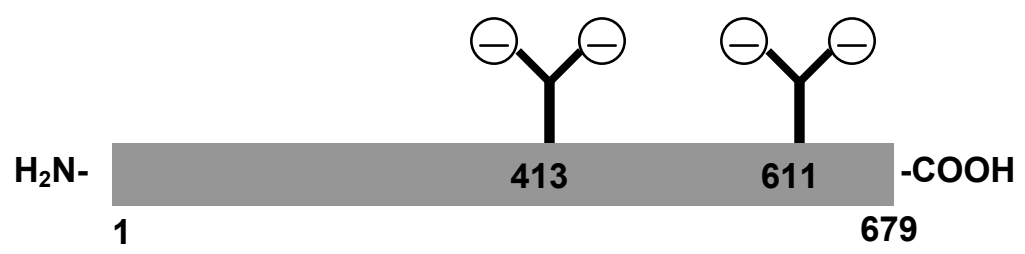

Abb. 3: $\quad$ Schematische Darstellung des humanen Serum-Transferrins. Das Serum-

Transferrin ist an den Asparaginresten 413 und 611 jeweils mit einem biantennären $\mathrm{N}$-Glykan vom komplexen Typ verknüpft und trägt vier terminale negativ geladene Sialinsäurereste (mit freundlicher Genehmigung von Dr. C. Thiel, Heidelberg).

Fehlen wie bei CDG-I-Typen eine oder beide N-Glykanseitenketten, verschiebt sich aufgrund des damit verbundenen Verlustes der negativ geladenen Sialinsäurereste der isoelektrische Punkt des Transferrins. In der isoelektrischen Fokussierung (IEF) zeigen sich damit neben einer vermindert ausgeprägten Tetrasialoform auch disialo- und asialo-Formen. Bei CDG-la liegt der Grund hierfür in Mutationen im Gen für das Enzym Phosphomannomutase II, welches im Zytosol 
die Umsetzung von Man-6-P zu Man-1-P katalysiert. Die verminderte Aktivität des Enzyms resultiert in einer Reduktion des GDP-Mannose-Pools (van Schaftingen und Jaeken, 1995; siehe Seite 14).

\subsection{CDG-la}

\subsubsection{Klinische Präsentation der CDG-la-Patienten}

Patienten mit CDG-la zeigen ein heterogenes Bild verschiedenster Symptome mit unterschiedlich starker Ausprägung. Dieses ist vor allem abhängig von der Restaktivität der Phosphomannomutase II, dem genetischen familiären Hintergrund sowie auch dem Lebensalter. Sinnvoll ist die Einteilung der Symptome nach einzelnen Organsystemen:

\section{NEUROLOGISCHE MANIFESTATIONEN:}

Bei Neugeborenen fällt frühzeitig eine axiale Hypotonie der Muskulatur auf. Hinzu können später eine periphere Muskelatrophie mit Verlust der tiefen Sehnenreflexe kommen (Kjaergaard et al., 2001). Die Nervenleitgeschwindigkeit ist ab dem sechsten bis achten Monat besonders an den unteren Extremitäten vermindert (Kristiansson et al., 1989; Jaeken und Stibler, 1989). Psychomotorische und mentale Retardierung, Dysarthrie, Ataxie sowie eine cerebelläre Hypoplasie sind übliche Befunde. Es wird auch von supratentoriellen Atrophien berichtet (Kjaergaard et al., 2001). Bei einigen Kindern bildet sich eine Epilepsie aus, die sowohl generalisierter als auch fokaler Natur sein kann (Kjaergaard et al., 2001). Ophthalmologisch findet man Nystagmen und einen Strabismus convergens. Später kann sich eine Retinopathia pigmentosa mit progressiver Blindheit entwickeln (Andréasson et al., 1991).

Auch können schlaganfallsartige Symptome mit Hemiplegie und/oder Koma auftreten, die sich aber meist vollständig zurückbilden (Jaeken und Stibler, 1989).

\section{GASTROINTESTINALE SYMPTOME:}

Es fällt im Allgemeinen eine Schwierigkeit bei der Nahrungsaufnahme auf. Die Kinder erhalten hochkalorische Ernährungszusätze, manche müssen durch Nasen- oder Magensonde ernährt werden. Besondere Probleme können durch 
Erbrechen, Diarrhoe, Steatorrhoe und Anorexie entstehen, woraus häufig eine Entwicklungsstörung resultiert (Petersen et al., 1993).

\section{LEBER-DYSFUNKTIONEN:}

Häufig läßt sich eine Hepatomegalie mit erhöhten Serum-Transaminasen nachweisen, die sich aber im weiteren Lebensverlauf meist normalisieren (Freeze 2001; Damen et al., 2004). Prothrombin, Antithrombin III, Protein C und S sowie auch die Konzentrationen von weiteren Fakoren der Gerinnungskaskade und Albumin sind meist erniedrigt (Van Geet und Jaeken, 1993). Daraus resultierende Blutgerinnungsstörungen können sowohl zu Blutungen als auch zu Thrombosen führen (Kjaergaard et al., 2001; Krasnewich et al., 2007).

\section{KARDIALE BETEILIGUNG:}

Echokardiographisch sieht man in vielen Fällen Perikardergüsse (Kjaergaard et al., 2001). Unter Umständen kann sich auch schnell nach der Geburt eine hypertrophe obstruktive Kardiomyopathie (HOCM) entwickeln (Clayton et al., 1992).

\section{ENDOKRINOLOGISCHE SYMPTOME:}

Bei weiblichen Patienten findet man einen hypergonadotropen Hypogonadismus, wodurch sie nicht in die Pubertät gelangen können. Die inneren Genitalien sind hypoplastisch und nur durch eine Östradiol-Therapie konnte bei einigen Mädchen eine Entwicklung der Brustdrüsen und Pubesbehaarung induziert werden (Kjaergaard et al., 2001). Auch bei den männlichen Patienten können minderentwickelte Hoden beobachtet werden.

\section{DYSMORPHE ZEICHEN:}

Neugeborene können je nach Schweregrad durch charakteristische dysmorphe Zeichen wie invertierte Brustwarzen und ungewöhnliche Fettansammlungen im Oberarm- und Gesäßbereich auffallen (Clayton et al., 1992), die allerdings transient sind (Kristiansson et al., 1989). Hinzu kommen schräg aufsteigende mandelförmige Augenlider und ein prominenter Unterkiefer mit weit voneinander entfernt stehenden bleibenden Zähnen. Auch können sich eine Kyphoskoliose und Osteopenie entwickeln (Kjaergaard et al., 2001). 
Die klinischen Symptome bei CDG-la-Patienten sind zum Teil sehr heterogen. Einige Patienten zeigen einen sehr leichten Verlauf auch ohne Einbeziehung der inneren Organe, andere wiederum leiden schon früh unter lebensbedrohlichen Komplikationen unterschiedlichster Ursache. Obligat bei allen CDG-la-Fällen sind aber axiale Hypotonie, cerebelläre Hypoplasie und Strabismus. Insgesamt liegt die Mortalität in den ersten Lebensjahren wegen schweren Infektionen, Herz- und Leberfunktionsstörungen bei 20\% (Jaeken und Carchon, 1993). Im späteren Lebensalter scheint sich die Erkrankung zu stabilisieren (Matthijs et al., 2000; Kjaergaard et al., 2002).

\subsubsection{Biochemie und Genetik von CDG-la}

Van Schaftingen und Jaeken berichteten 1995 über eine auf bis zu $10 \%$ des Normalen gesunkene Aktivität der Phosphomannomutase (PMM) in Fibroblasten von CDG-la-Patienten. Im Zytosol setzt dieses Enzym Mannose-6-Phosphat zu Mannose-1-Phosphat um. Aufgrund der verringerten Aktivität resultiert eine verminderte Konzentration der nachfolgenden Intermediate Mannose-1-Phosphat, GDP-Mannose, GDP-Fucose und Dol-P-Man (Rush et al., 2000). Das Substrat Mannose-6-Phosphat ist dabei nicht erhöht. Während gesunde Fibroblasten überwiegend Dol-P-P-GlcNAc $-\mathrm{Man}_{9} \mathrm{Glc}_{3}$ produzieren, werden in Fibroblasten von CDG-la-Patienten durch den Mangel an Intermediaten vor allem verkürzte Dolichol-verknüpfte Oligosaccharide synthetisiert. Diese werden durch den Oligosaccharyltransferase-Komplex mit geringerer Effizienz übertragen. Im Fall des Markerproteins Transferrin entstehen daher zur Hälfte Glykoproteine mit nur einer der beiden Oligosaccharidketten. Verkürzte Glykanstrukturen kommen nicht vor (Yamashita et al., 1993; Wada et al., 1992,1994).

Es wurden nachfolgend zwei Isoenzyme für PMM entdeckt, PMM1 und PMM2 (Matthijs et al., 1997a,b), die sich durch ihre Kinetik, Antigenität und Struktur unterscheiden. Bis jetzt konnte aber nur PMM2 (OMIM 601785) mit fast 90 verschiedenen Mutationen in über 400 Familien als Auslöser für CDG-la eruiert werden. Krankheitsauslösende Mutationen in PMM1 (OMIM 601786) sind bis jetzt nicht beschrieben worden; auch zeigte ein Pmm1-Knock-Out-Mausmodell keinen 
pathologischen Phänotyp (Cromphout et al. 2006), so dass die physiologische Funktion des Proteins bislang unklar ist.

Das Gen für PMM2 liegt auf Chromosom $16 p 13$ und codiert für ein 246 Aminosäuren langes Protein. Bei den bislang identifizierten Mutationen handelt es sich meistens um Missense-Mutationen, die auf Grund von Basenaustauschen entstehen. Daneben gibt es seltene Mutationen, die zu Frameshift- oder SpliceVarianten führen. Betrachtet man die Verteilung der Mutationen auf dem acht Exons enthaltenden Gen, fält auf, dass die meisten Mutationen auf den Exons 5 und 8 lokalisiert sind.

Die beiden häufigsten Mutationen sind R141H (422 G>A) und F119L (357 C>A) mit einem Anteil von $35 \%$ respektive $13 \%$ aller mutierten Allele. Einen interessanten Aspekt stellt die geographische Verteilung dieser beiden Mutationen dar. R141H wurde in allen kaukasischen Populationen gefunden und variiert von $23 \%$ in Spanien bis $45 \%$ in Belgien. Analysen des Haplotyps weisen für $\mathrm{R} 141 \mathrm{H}$ auf eine sehr alte Mutation hin, die sich im Laufe der Zeit sehr weit verbreitet hat (Schollen et al., 2000). Für F119L gibt es einen eindeutigen Schwerpunkt in SüdSkandinavien. In Dänemark ist diese Mutation mit 48\% an allen PMM2-Mutationen beteiligt, während sie im Mittelmeerraum noch nicht beobachtet wurde. Nimmt man beide Mutationen zum Genotyp R141H/F119L zusammen, deckt man in Skandinavien $72 \%$ der CDG-la-Genotypen ab.

Bei dem Genotyp R141H/R141H ist es anders. Obwohl anhand der beobachteten Träger-Frequenz für $\mathrm{R} 141 \mathrm{H}$ von 1/72 $(\mathrm{q})$ in der dänischen und niederländischen Bevölkerung unter Beachtung des Hardy-Weinberg-Gesetzes $\left(p^{2}+2 p q+q^{2}=1\right)$ eine Homozygoten-Quote von 1/20.700 $\left(q^{2}\right)$ zu erwarten wäre und dieser Genotyp demnach zu $45 \%$ bis $60 \%$ unter den CDG-la-Patienten zu finden sein müsste, wurde bis jetzt nicht ein einziger Patient entdeckt (Kjaergaard et al., 1998; Matthijs et al., 1998; Bjursell et al., 2000). Dies lässt vermuten, dass dieser Genotyp letal ist (Schollen et al., 2000). Unterstützt wird die These durch Untersuchungen an rekombinanten $\mathrm{R} 141 \mathrm{H}-$ Proteinen, deren enzymatische Aktivität gegen null geht (Pirard et al., 1999). Im Gegensatz dazu zeigen Mutationen wie F119L und D65Y deutlich höhere Restaktivitäten und konnten auch als homozygoter Genotyp nachgewiesen werden. Homozygotien oder compound-Heterozygotien für 
Mutationen, die eine Phosphomannomutase ohne Restaktivität erzeugen, scheinen letal zu sein (Matthijs et al., 2000).

\section{$1.5 \quad$ Zielsetzung}

Unter den bisher bekannten CDG-Syndromen ist CDG-la die häufigste Erkrankung. Dennoch sind viele Fragen im Bereich Biochemie, Pathophysiologie und Klinik unklar. Bisher unternommene Therapieversuche haben sich bei Patienten als erfolglos erwiesen. Um weiterführende Untersuchungen zu ermöglichen, soll ein Mausmodell generiert werden.

Um einen Phänotyp zu schaffen, der dem Menschen möglichst ähnlich ist und die Probleme einer embryonalen Letalität umgeht, wurden zwei Modelle geplant, welche die entsprechenden humanen Mutationen F119L und R141H tragen. Da das Pmm2-Enzym der Maus etwas kürzer als das menschliche ist, sind die zu generierenden murinen Mutationen $\mathrm{F} 115 \mathrm{~L}$ und $\mathrm{R} 137 \mathrm{H}$.

Verpaarungen dieser rekombinanten Mäuse würden dann eine phänotypische Bandbreite vom milden bis hin zum schwer ausgeprägten klinischen Bild hervorbringen.

Die vorliegende Arbeit befasst sich mit der Herstellung zweier, mittels der KnockIn-Strategie generierten, Gene-Targeting-Vektoren, die zur Transfektion embryonaler Mausstammzellen genutzt werden können. Nach erfolgreichem Einbau dieser Vektoren durch homologe Rekombination sollen die transgenen Stammzellen in Mausembryonen, die sich im Blastozystenstadium befinden, mikroinjiziert werden. Daraus entstandene Chimären könnten nach entsprechenden Verpaarungen Mausmodelle mit den Genotypen F115L/F115L und F115L/R137H erzeugen. 


\section{Material und Methoden}

\section{$2.1 \quad$ Material}

\subsubsection{Geräte}

Analysenwaagen Typ M5P und CP3202P

Biofuge pico

Brutschrank Typ 2771

DNA-Sequenzer Typ 310

Durchlicht-Mikroskop Typ ID03

Eismaschine

Elektrophoresekammern für Agarosegele

Elektroporator Typ Gene Pulser

Eppendorfzentrifugen Typ 5402, 5414, $5415 \mathrm{D}$

Eraser für Phosphoimager-Screens

Filmentwicklungsmaschine Typ Curix 60

Fujix Bio Imaging Analyzer Typ BAS 1000

Gefrierschrank $-80^{\circ} \mathrm{C}$

GeneAmp PCR System 2400

GeneAmp PCR System 2700

Handcounter Typ LB122

Heizblock Typ Thermostat 5320

Inkubationsschüttler Typ G25

Inkubator mit Drehrad

Inkubator, wasserummantelt, geregelte

$\mathrm{CO}_{2}$-Atmosphäre

JA-10/20-Rotoren für Kühlzentrifuge Typ J2-MC
Sartorius, Göttingen

Heraeus, Osterode

Heraeus, Osterode, Köttermann, Häningsen

ABI Applied Biosystems, Foster City, USA

Zeiss, Oberkochen

Ziegra, Isernhagen

Eigenbau, Werkstatt des Instituts

BioRad, München

Eppendorf, Hamburg

Raytest, Straubenhardt

Agfa-Gevaert, Leverkusen

Fuji, Elmsford, USA

Colora Messtechnik, Lorch

Perkin Elmer. Wellesley, USA

Applied Biosystems, Foster City,

USA

Berthold, Bad Wildbad

Eppendorf, Hamburg

New Brunswick Scientific, Edison, USA

Schütt Labortechnik, Göttingen

Forma Scientific, Marietta, USA

Beckmann, München 
Kapazitätserweiterer für Elektroporator

Kühlzentrifuge Typ J2-MC

Kühlzentrifuge Typ MikroRapid/K

Magnetrührer Typ Ika-Combimag Reo

Micro-Pipetten $(20,200,1000 \mu \mathrm{l})$

Microprep Zentrifuge

Mikrowellenherd

pH-Meter Typ InoLab

Pipette $(10 \mu \mathrm{l})$

Pipettierhilfe Typ Pipet Aid XP

Schüttelwasserbad

Spannungsgeräte

Spektralphotometer Typ Uvikon 932

Sterilbank Typ Lamin Air HLB2448

Sterilbank Typ SG400

Stickstofftank Biosafe Chronos

Thermomixer Typ compact und 5436

Typ Tecnoclav 50

Video-Drucker

Video-Kamera

Vortex-Genie 2

Waage Typ 1265MP

Wärmeschrank

Wasserbad Typ 1003

Wipptisch Typ Rocky

Zentrifuge Typ Labofuge
BioRad, München

Beckmann, München

Hettich, Tuttlingen

Janke \& Kunkel, Staufen

Gilson, Middleton, USA

Stat Spin Technologies, Norwood, USA

Siemens, München

WTW, Weilheim

Eppendorf, Hamburg

Drummond, Broomall, USA

Köttermann, Häningsen, Göttingen

Hölzel, München

Kontron Instruments, Eching

Heraeus, Osterode

Baker Company, Sanford, USA

Messer, Griesheim

Eppendorf, Hamburg

Tecnorama, Zürich, Schweiz

Intas, Göttingen

Intas, Göttingen

Bender \& Hobein, Zürich, Schweiz

Sartorius, Göttingen

Memmert, Schwabach

Gesellschaft für Labortechnik, Burgwedel

Itf Labortechnik, Wasserburg

Heraeus, Osterode

\subsubsection{EDV}

Hardware: 
Apple Laser Writer Typ 16/600 PS

Scanner Typ CanoScan D660U

Software:

Adobe-Photoshop 6.0

DNAStar (MegAlign, MapDraw,

Protean, EditSeq)

Windows 98

Windows Office 98 (Word, Power

Point)

Image Reader

Image Gauge 3.0

ClarisWorks

\subsubsection{Verbrauchsmaterial}

6- bzw. 24-Napf-Zellkulturplatten

Einfrierkästen

Elektroporationsküvetten

Gewebekulturschalen $(3,6,10,15 \mathrm{~cm})$

Glaskolben

Hybond-N Filter (82 mm, $132 \mathrm{~mm}$ )

Kryoröhrchen

Parafilm

Pasteurpipetten

PCR-Gefäße Multiply-Pro (0,2 ml)

Phosphoimager-Screen

Pipettenspitzen

Plastikpipetten, steril $(2,5,10,25 \mathrm{ml})$

Plastik-Reaktionsgefäße $(0,5 ; 1,5 ; 2 \mathrm{ml})$

Plastikröhrchen (10, 15, $50 \mathrm{ml})$

Plastik-Spritzen Ecoject, steril (10 ml)
Apple Macintosh, Cupertino, USA

Canon, Krefeld

Adobe, San Jose, USA

DNAStar, Madison, USA

Microsoft, Bellevue, USA

Microsoft, Bellevue, USA

Fuji, Elmsford, USA

Fuji, Elmsford, USA

Claris Corporation, Santa Clara, USA

Greiner, Nürtingen

National Lab, Mölln

Biorad, München

Greiner, Nürtingen

Schott, Mainz

Amersham, Braunschweig

Nunc, Wiesbaden

American National, Chicago, USA

Schütt, Göttingen

Sarstedt, Nümbrecht

Fuji, Elmsford, USA

Sarstedt, Nümbrecht

Greiner, Nürtingen

Sarstedt, Nümbrecht

Sarstedt, Nümbrecht

Dispomed Witt, Gelnhausen 
Röntgenfilme XAR-5

Skalpelle, steril

Sterilfilter $(0,2$ und $0,45 \mu \mathrm{m})$

Whatman-Papier (3 mm)

Zentrifugenbecher (JA 10/20

Polypropylen)
Kodak, Stuttgart

Braun, Melsungen

Sartorius, Göttingen

Whatman-Vertrieb, Göttingen

Beckmann, München

\subsubsection{Chemikalien}

Die Chemikalien wurden von den Firmen Difco, Detroit, USA; Merck, Darmstadt; Pharmacia, Freiburg; Sigma, Deisenhofen und Serva, Heidelberg im Reinheitsgrad pro analysi bezogen.

Agar

Agarose

Bacto-Hefe-Extrakt

Bacto-Trypton

Dextransulfat

EDTA- $\mathrm{Na}_{2} \times \mathrm{H}_{2} \mathrm{O}$

Ethanol

Ethidiumbromid

Ficoll

$\mathrm{H}_{2} \mathrm{O}$ HPLC-Reinheitsgrad

IPTG

Natriumacetat

$\mathrm{NaCl}$

SDS

$\mathrm{NaOH}$

Polyvinylpyrrolidon

$\mathrm{HCl}$

Tris

X-Gal
Sigma

Sigma

Difco

Difco

Pharmacia

Merck

Merck

Serva

Sigma

Merck

Sigma

Merck

Merck

Sigma

Merck

Serva

Merck

Merck

Sigma 


\subsubsection{Puffer und Stammlösungen}

Alle verwendeten Lösungen wurden nach Vorschriften aus dem Laborhandbuch von Sambrook et al. (1989) angesetzt. Das verwendete Wasser wurde zuvor doppelt destilliert.

$1 \mathrm{M} \mathrm{Tris} / \mathrm{HCl} \quad 121,1 \mathrm{~g}$ Tris wurden in $800 \mathrm{ml} \mathrm{H} \mathrm{H}_{2} \mathrm{O}$ gelöst, der pH-Wert mit konzentrierter $\mathrm{HCl}$ auf Werte zwischen 7,2 und 9,0 eingestellt, das Volumen auf 1 I eingestellt und autoklaviert.

20 x SSC $\quad 175,3 \mathrm{~g} \mathrm{NaCl}$ und $88,2 \mathrm{~g} \mathrm{Na}$-Citrat wurden in $\mathrm{H}_{2} \mathrm{O}$ gelöst, der $\mathrm{pH}-$ Wert auf 7,0 eingestellt und das Volumen auf $1 \mathrm{I}$ aufgefüllt.

$50 \times$ Denhardts $\quad 1 \%$ Ficoll, $1 \%$ Polyvinylpyrrolidon und $1 \% \mathrm{BSA}$ in $\mathrm{H}_{2} \mathrm{O}$

0,5 M EDTA $\quad 181,1 \mathrm{~g}$ EDTA- $\mathrm{Na}_{2} \times 2 \mathrm{H}_{2} \mathrm{O}$ wurden in $800 \mathrm{ml} \mathrm{H} \mathrm{H}_{2} \mathrm{O}$ gelöst, der $\mathrm{pH}-$ Wert mit $20 \mathrm{~g} \mathrm{NaOH}$ oder konzentrierter Natronlauge auf 8,0 eingestellt, das Volumen auf 1 I aufgefüllt und autoklaviert.

Weitere spezielle Lösungen sind bei der entsprechenden Methode aufgeführt.

\subsubsection{Medien zur Anzucht prokaryontischer Zellen}

LB-Medium: $10 \mathrm{~g}$ Bacto-Trypton, $5 \mathrm{~g}$ Bacto-Hefe-Extrakt und $5 \mathrm{~g} \mathrm{NaCl}$ wurden in $800 \mathrm{ml} \mathrm{H}_{2} \mathrm{O}$ bidest. gelöst, auf $\mathrm{pH}$ 7,5 eingestellt, mit $\mathrm{H}_{2} \mathrm{O}$ bidest. auf 1 I aufgefüllt und autoklaviert. Zur selektiven Bakterienanzucht wurde Ampicillin mit einer Endkonzentration von $200 \mu \mathrm{g} / \mathrm{ml}$ zugefügt.

Zur selektiven Bakterienanzucht auf Agarplatten wurden dem LB-Medium vor dem Autoklavieren $15 \mathrm{~g}$ Agar pro Liter zugesetzt. Nach dem Autoklavieren und einer Abkühlung auf $50^{\circ} \mathrm{C}$ wurde Ampicillin mit einer Endkonzentration von $200 \mu \mathrm{g} / \mathrm{ml}$ zugefügt. Die Agarlösung wurde in 9-cm-Petrischalen gegossen, bei RT abgekühlt und anschließend bei $4^{\circ} \mathrm{C}$ unter Lichtausschluss gelagert. 


\subsubsection{Zellkulturmedien, Medienzusätze und Lösungen zur Arbeit mit eukaryontischen Zellen}

Medien, Medienzusätze und Lösungen wurden von den Firmen Boehringer, Mannheim; Gibco BRL, Eggenstein; Merck, Darmstadt; Serva, Heidelberg und Sigma, München bezogen.

BSA

$\beta$-Mercaptoethanol, $14 \mathrm{M}$

DMSO

DMEM, Knock-Out

FKS, (ES-Cell tested)

LIF

L-Glutamin

MEM/HEPES

Mitomycin C

Na-Pyruvat

non-essential amino acids

PBS

Trypsin-EDTA, $(0.25 \%$ und $0.05 \%)$
Serva

Sigma

Merck

Gibco BRL

Hyclone,

Chemicon

Gibco BRL

Gibco BRL

Sigma

Gibco BRL

Gibco BRL

Gibco BRL

Gibco BRL

Weitere spezielle Medien und Lösungen sind bei der entsprechenden Methode aufgeführt.

\subsubsection{Enzyme, Standards und Antibiotika}

1-kb-Ladder

Ampicillin

Geneticin ${ }^{\circledR}$ (G418)

Penicillin/Streptomycin

Pfu-Turbo-DNA-Polymerase

Alkalische Phosphatase

Proteinase $\mathrm{K}$
Gibco BRL, Eggenstein

Calbiochem, Frankfurt

Gibco BRL, Eggenstein

Gibco BRL, Eggenstein

Stratagene, Heidelberg

Boehringer, Mannheim

Boehringer, Mannheim 
Restriktionsendonukleasen

T4-DNA-Ligase

Taq-DNA-Polymerase

Ultrapure dNTP Set
New England Biolabs, Beverly, USA; MBI Fermentas, St. Leon-Rot MBI Fermentas, St. Leon-Rot

Pharmacia, Freiburg

Pharmacia, Freiburg

\subsubsection{Oligonukleotide}

Die verwendeten Oligonukleotide (Primer) wurden von der Firma IBA-Naps, Göttingen bezogen.

\subsubsection{Kits zur Bearbeitung von DNA}

ABI PRISM Dye Terminator

AccuPrime $^{\mathrm{TM}}$-Taq-DNA-Polymerase

Hot-Star-Taq-PCR-Kit

QIA-Plasmid Midi Kit

QIA-Plasmid Mini Kit

QIAquick Gel Extraction Kit

QuickChange in-vitro-Mutagenese-Kit

RediPrime II DNA Labeling Kit

T4-Cloning Kit

\subsubsection{Radioaktive Substanzen}

$\alpha-\left[{ }^{32} P\right]-d C T P$, Redivue
Perkin Elmer Cetus, Norwalk, USA

Invitrogen, Karlsruhe

Qiagen, Hilden

Qiagen, Hilden

Qiagen, Hilden

Qiagen, Hilden

Stratagene, Heidelberg

Amersham Pharmacia,

Braunschweig

New England Biolabs, Beverly, USA

Amersham-Buchler, Braunschweig 


\subsubsection{Vektoren}

pBlueScript SK II (+/-) S Stratagene, Heidelberg

\subsubsection{Bakterienstämme}

Zur Amplifikation von DNA im Prokaryontensystem wurden Escherichia-coliBakterien des Stamms XL-Blue (Genotyp: $\mathrm{F}^{\prime}:: \operatorname{Tn} 10 \operatorname{proA}^{+} \mathrm{B}^{+} \quad$ lacl $^{q} \quad \Delta$ (lacZ)M15/recAl endAl gyrA96(Nal) thi hsdR17 (rKmK+) supE44 relAl lac) verwendet.

\subsubsection{Embryonale Stammzellen}

Die verwendeten, als E-14.1 bezeichneten Zellen wurden aus Blastozysten von 129/Ola-Mäusen isoliert und von der Arbeitsgruppe von K. Rajewsky, Köln bezogen.

\subsubsection{Embryonale Mausfibroblasten (Feeder)}

Die embryonalen Stammzellen wurden auf einem Feederrasen aus G418 ${ }^{\circledR}$ (Neomycin)-resistenten mausembryonalen Fibroblasten kultiviert. Diese wurden aus Embryonen transgener Mäuse gewonnen, die eine Resistenz gegen Neomycin besitzen (Müller et al., 1991). Tragende transgene Mäuse dieses Stammes wurden freundlicherweise von der Arbeitsgruppe K. Rajewsky, Köln zur Verfügung gestellt.

\subsubsection{Mausstämme}

Blastozysten wurden nach natürlichen Verpaarungen aus folgendem Mausstamm (Mus musculus) isoliert: 
Als Ammen-Mütter dienten Mäuse des folgenden Stammes:

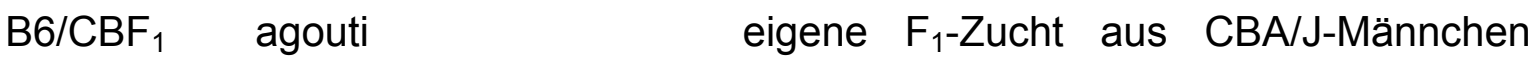
(Inzuchtstamm, agouti; BRL, Basel, Schweiz) und C57BL/6J-Weibchen

Sterile Männchen für die Bereitstellung pseudoträchtiger B6/CBF 1 -Weibchen (Foster-Mäuse) wurden durch Vasektomie der Männchen des folgenden Stammes generiert:

Moro Inzuchtstamm, weiß BRL, Basel, Schweiz

\subsection{Molekularbiologische Methoden}

\subsubsection{Genmanipulation}

Die Möglichkeit, eine Maus als Modell für menschliche, genetisch-bedingte Erkrankungen zu nutzen, wurde durch zwei wichtige Entwicklungen erreicht. 1981 gelang es zwei Laboratorien, embryonale Stammzellen (ES-Zellen) aus frühen Maus-Embryonen zu isolieren und zu kultivieren (Martin, 1981; Evans und Kaufman, 1981). Diese besaßen die Eigenschaften der Pluripotenz, unbegrenzter Selbst-Erneuerung in vitro und die Fähigkeit, sich im Gewebe einer Wirtsblastozyste zu entwickeln (Bradley et al., 1984). Des Weiteren wurde die Fähigkeit von Säuger-Zellen beschrieben, eingebrachte DNA mit eigenen dazu homologen Sequenzen zu rekombinieren (Smithies et al., 1985; Wong und Capecchi, 1986). Später wurde dies auch für ES-Zellen belegt (Thomas und Capecchi, 1987). Im Gegensatz zu früheren Methoden, die chemische und physikalische Mutagenzien benutzten, ist es heute möglich, spezifische und gezielte Änderungen im Genom einer Maus vorzunehmen. 


\subsubsection{1 „gene targeting“ durch homologe Rekombination in murinen ES-Zellen}

Der molekularbiologische Mechanismus der gezielten Änderung des Genoms (,gene targeting") einer Maus durch homologe Rekombination ist noch nicht genau geklärt, scheint aber den „crossing over"-Vorgängen bei der Meiose zu ähneln. Durch Elektroporation lagert sich die in ES-Zellen eingebrachte DNA, z.B. ein "Gene-Targeting-Vector" (GTV), an homologe DNA Abschnitte des residenten Genoms an. Vermutlich ermöglichen ein Einzel- oder Doppelstrangbruch im MausChromosom und anschließende Reparatur-Mechanismen den Einbau des GTV und somit den Austausch der beiden homologen Gen-Bereiche (Hasty et al., 1992; Ramdas et al., 1991; Aratani et al., 1992; Orr-Weaver und Szostak, 1983; Valancius und Smithies, 1991). Der mittels molekularbiologischer Methoden konstruierte GTV kann erwünschte Modifikationen wie z.B. Punktmutationen enthalten. Da die homologe Rekombination in Säugerzellen ein seltenes Ereignis ist, wird in den GTV zusätzlich ein Selektionsmarker, z.B. eine Neomycin (Neo)Kassette, eingefügt, welche eine Resistenz gegenüber dem Antibiotikum Geneticin $\left(G 418^{\circledR}\right.$ ) vermittelt (Capecchi, 1989). Das Aminoglykosid Geneticin blockiert die Proteinbiosynthese, kann aber durch die bakterielle AminoglykosidPhosphotransferase, codiert durch die Neomycin-Kassette, inaktiviert werden. Diese Positiv-Selektion ermöglicht das Erfassen von ES-Zellen, die zumindest die Neo-Kassette in ihr Genom aufgenommen haben und die Phosphotransferase exprimieren.

Des Weiteren wird die Effizienz der homologen Rekombination von mehreren Faktoren beeinflusst. Die DNA des verwendeten GTV und die embryonalen Stammzellen sollten gleicher Herkunft sein bzw. dem selben Mausstamm entspringen (te Riele et al., 1992). Ein weiterer wichtiger Faktor sind möglichst lange genomische Homologien zwischen GTV und dem Zielgen (Deng und Capecchi, 1992).

ES-Zellen, die durch $\mathrm{G} 418^{\circledR}$ selektioniert wurden und in denen die homologe Rekombination nachgewiesen werden konnte, werden durch Mikroinjektion in Mausembryonen des Blastozystenstadiums gebracht. Wandern diese Zellen nun in den Embryonalpool der Blastozyste ein, entsteht eine chimäre Maus. Falls diese ES-Zellen sich an der Entwicklung der Keimzellen beteiligt haben, können 
Verpaarungen dieser Chimären Nachkommen hervorbringen, die das mutierte Genom vollständig übernommen haben (Bradley et al., 1984).

\subsubsection{Knock-Out-Maus}

Mit Hilfe der oben genannten Techniken ist es möglich, ein Gen gezielt auszuschalten. Ein etabliertes Verfahren, um diese sogenannten „Knock-Out“Mäuse zu generieren, ist das Einbringen eines Selektionsmarkers, wie z.B. eine Neo-Kassette, in ein Exon des entsprechenden Gens. Der Leserahmen des Gens wird dadurch unterbrochen und mit hoher Wahrscheinlichkeit ein Funktionsverlust herbeigeführt (Capecchi, 1989).

\subsubsection{Hypomorphes Mausmodell}

Eine Möglichkeit einen vollständigen Funktionsverlust eines Gens zu vermeiden und lediglich das Gen dahingehend zu verändern, dass eine eingeschränkte Funktion des codierenden Proteins resultiert (hypomorphes Allel), ist das Cre/loxP-Rekombinations-System. Das Cre-Protein gehört in die Gruppe der DNARekombinasen und wurde in dem Bakteriophagen P1 entdeckt (Sternberg und Hamilton, 1981; Hoess et al., 1982; Argos et al., 1986). Die Cre-Rekombinase erkennt und bindet an eine spezifische DNA-Sequenz, genannt loxP. Befinden sich zwei dieser loxP-Sequenzen auf dem gleichen DNA-Molekül und besitzen beide dieselbe Orientierung, so wird der dazwischen liegende DNA-Bereich herausgeschnitten und abgebaut. Diese Erkenntnis kann man dazu nutzen, „saubere“ Mutationen, z.B. eine Punktmutation, im Mausgenom zu generieren („Knock-In“). Dazu wird ein GTV verwendet, der zusätzlich zu dieser Punktmutation eine Selektionskassette besitzt, die von zwei loxP-Sequenzen eingeschlossen ist und in einem Intron liegt. Nach der Cre-Rekombinase-Reaktion liegt neben der eingebrachten Punktmutation lediglich eine loxP-Sequenz mit der Länge von 34 Basenpaaren als Artefakt im Genom vor. Diese Reaktion kann 
sowohl auf der Ebene der ES-Zellen per Elektroporation, als auch später durch Verpaarung der Maus mit einer genetisch manipulierten „Cre-Maus“, die das CreRekombinase-Gen in ihrem Genom enthält, durchgeführt werden. Zudem gibt es Möglichkeiten, die Cre-Rekombinase mittels Viren organspezifisch zu exprimieren.

\subsubsection{Standardbedingungen und -methoden der Molekularbiologie}

Alle gentechnologischen Arbeitsschritte wurden nach molekularbiologischen Standardmethoden und unter Beachtung der jeweiligen Sicherheitsvorschriften durchgeführt. Reagenzien und Proben für enzymatische Reaktionen wurden in der Vorbereitung auf Eis gekühlt. Nicht käuflich erworbene Medien, Puffer und sonstige Lösungen wurden mit bidestilliertem Wasser angesetzt und gegebenenfalls durch Autoklavieren oder Filtrieren sterilisiert.

Die im Folgenden beschriebenen Methoden und Vorschriften wurden dem Laborhandbuch "Molecular cloning" (Sambrook et al., 1989) entnommen, sofern es nicht anders angegeben ist.

\subsubsection{Konzentrationsbestimmung von Nukleinsäuren}

Die Konzentration von DNA bzw. RNA wurde photometrisch ermittelt. Die Messung erfolgte bei einer Wellenlänge von $260 \mathrm{~nm}$ gegen $\mathrm{H}_{2} \mathrm{O}$ in einer Quarzküvette. $\mathrm{OD}_{260}=1$ entspricht einer Konzentration von $50 \mu \mathrm{g} / \mathrm{ml}$ doppelsträngiger DNA bzw. $40 \mu \mathrm{g} / \mathrm{ml}$ RNA. Die Verunreinigung der DNA/RNAProbe durch Protein wurde anschließend bei $280 \mathrm{~nm}$ gemessen. Hierbei sollte sich für reine DNA ein Wert von $\mathrm{OD}_{260}: \mathrm{OD}_{280}$ von 1,8 ergeben. 


\subsubsection{Spaltung von DNA mit Restriktionsendonukleasen}

(Lehrach und Frischauf, 1982)

Die Aktivität von Restriktionsendonukleasen wird in Units $(U)$ angegeben. Eine Unit entspricht der Menge an Restriktionsenzym, die benötigt wird, um $1 \mu \mathrm{g}$ Lambda-DNA in einer Stunde vollständig zu verdauen. Um sicherzustellen, dass der Verdau quantitativ abläuft, wurde die Enzymmenge und die Inkubationszeit verdoppelt. Der Verdau genomischer DNA erfolgte über Nacht.

Reaktionsansatz:

$$
\begin{aligned}
\text { x } \mu \mathrm{g} & \text { DNA } \\
2 \mu \mathrm{l} & \text { 10x Puffer (nach Angaben der Hersteller) } \\
2 \mu \mathrm{l} & \text { 10x BSA (falls nach Angaben der Hersteller } \\
& \text { erforderlich) } \\
2 \mathrm{U} & \text { Restriktionsendonuklease } \\
\text { ad } 20 \mu \mathrm{l} & \mathrm{H}_{2} \mathrm{O} .
\end{aligned}
$$

Der Ansatz wurde $2 \mathrm{~h}$ bei $37^{\circ} \mathrm{C}$ (bzw. dem jeweiligen Temperaturoptimum des Enzyms) inkubiert und anschließend im Agarosegel analysiert. Präparative Verdaue wurden in größeren Volumina und mit entsprechend größerer Enzymmenge durchgeführt.

Die Reaktionspuffer wurden gemäß dem New England Biolab (NEB)- bzw. dem MBI Fermentas-Puffersystem verwendet. Diese Puffer werden von den Herstellern zusammen mit den Enzymen geliefert.

Das NEB-Puffersystem besteht neben enzymspezifischen Puffern aus vier Basispuffern:

NEB 1: $\quad 10 \mathrm{mM}$ Bis-Tris Propan/ $\mathrm{HCl}(\mathrm{pH} 7,0)+10 \mathrm{mM} \mathrm{MgCl}_{2}+1 \mathrm{mM}$ DTT

NEB 2: $\quad 10 \mathrm{mM} \mathrm{Tris/HCl}(\mathrm{pH} 7,9)+10 \mathrm{mM} \mathrm{MgCl} 2+1 \mathrm{mM} \mathrm{DTT}+50 \mathrm{mM} \mathrm{NaCl}$ NEB 3: $\quad 50 \mathrm{mM} \mathrm{Tris/HCl}(\mathrm{pH} 7,9)+10 \mathrm{mM} \mathrm{MgCl} 2+1 \mathrm{mM} \mathrm{DTT}+100 \mathrm{mM}$ $\mathrm{NaCl}$

NEB 4: $\quad 20 \mathrm{mM}$ Tris/Ac $(\mathrm{pH} 7,9)+10 \mathrm{mM} \mathrm{MgAc} 2+1 \mathrm{mM} \mathrm{DTT}+50 \mathrm{mM} \mathrm{KAc}$

Das MBI-Puffersystem besteht neben enzymspezifischen Puffern aus fünf Basispuffern:

$\mathrm{B}^{+}: \quad 10 \mathrm{mM}$ Tris/HCl $(\mathrm{pH} 7,5)+10 \mathrm{mM} \mathrm{MgCl} 2+0,1 \mathrm{mM} \mathrm{BSA}$ 
$\mathrm{G}^{+}: \quad 10 \mathrm{mM}$ Tris/ $\mathrm{HCl}(\mathrm{pH} 7,5)+10 \mathrm{mM} \mathrm{MgCl}_{2}+0,1 \mathrm{mM} \mathrm{BSA}+50 \mathrm{mM} \mathrm{NaCl}$

$\mathrm{O}^{+}: \quad 10 \mathrm{mM}$ Tris/ $\mathrm{HCl}(\mathrm{pH} 7,5)+10 \mathrm{mM} \mathrm{MgCl}_{2}+0,1 \mathrm{mM} \mathrm{BSA}+100 \mathrm{mM} \mathrm{NaCl}$

$\mathrm{R}^{+}: \quad 10 \mathrm{mM}$ Tris $/ \mathrm{HCl}(\mathrm{pH} 8,5)+10 \mathrm{mM} \mathrm{MgCl}_{2}+0,1 \mathrm{mM} \mathrm{BSA}+100 \mathrm{mM} \mathrm{KCl}$

$\mathrm{Y}^{+}: \quad 33 \mathrm{mM}$ Tris/Ac $(\mathrm{pH} 7,9)+10 \mathrm{mM} \mathrm{MgAc}_{2}+0,1 \mathrm{mM} \mathrm{BSA}+66 \mathrm{mM} \mathrm{KAc}$

Alle angegebenen Konzentrationen sind 1x-Konzentrationen; die Puffer wurden in 10x-Konzentrationen geliefert.

\subsubsection{Auftrennung von DNA-Fragmenten in Agarosegelen}

Zur Auftrennung von DNA-Fragmenten wurden Agarosegele verwendet, deren Agarosekonzentration sich nach der Größe der zu trennenden DNA-Fragmente richtete:

$\begin{array}{cc}\text { Agarosekonzentration [\%] } & \text { Trennbereich [kb] } \\ 0,6 & 1-20 \\ 0,9 & 0,5-7 \\ 1,2 & 0,4-6 \\ 1,5 & 0,2-4 \\ 2,0 & 0,1-3\end{array}$

Die erforderliche Agarosemenge wurde in $400 \mathrm{ml}$ 1X-TAE im Mikrowellenherd aufgekocht und nach Abkühlen auf $55^{\circ} \mathrm{C}$ mit Ethidiumbromid versetzt (Endkonzentration: 0,5 $\mu \mathrm{g} / \mathrm{ml}$ ). Die Lösung wurde in eine Gelform gegossen und bei RT abgekühlt. Das erstarrte Gel wurde in eine mit 1x-TAE gefüllte Elektrophoresekammer überführt, die Proben wurden mit DNA-Auftragspuffer (10\%ige Zusammensetzung) versetzt und in die vorgeformten Geltaschen pipettiert. Die Elektrophorese wurde mit einer Spannung von 3-4 V/cm ${ }^{2}$ durchgeführt. Durch das in die DNA-Doppelhelix interkalierende Ethidiumbromid wurden die DNA-Fragmente unter UV-Licht mit $260 \mathrm{~nm}$ Wellenlänge sichtbar, so dass das Gel auf dem UV-Transilluminator analysiert werden konnte. Zur Dokumentation wurde das Agarosegel auf dem UV-Transilluminator mit einem Videosystem aufgenommen und ein Ausdruck des Bildes erstellt. 


\subsubsection{Isolierung von DNA-Fragmenten aus Agarosegelen}

(QIAquick Gel Extraction Kit, Handbuch, 1999)

Lösungen: Die Zusammensetzung der Puffer wird von Qiagen nicht angegeben.

Die zu isolierende DNA-Bande wurde unter UV-Licht (UV-Handlampe) aus dem Agarosegel ausgeschnitten und das Gelstück gewogen. Nach Zugabe von 3 Volumen QG-Puffer wurde die Agarose durch Inkubation über $10 \mathrm{~min}$ bei $50^{\circ} \mathrm{C}$ aufgelöst. Die Lösung wurde auf eine QIAquick-Zentrifugationssäule aufgebracht und für eine Minute bei $13000 \mathrm{rpm}$ in der Eppendorfzentrifuge zentrifugiert, wobei die DNA an die Säule bindet. Nach Waschschritten mit $500 \mu$ l QG-Puffer und 700 $\mu \mathrm{l}$ PE-Puffer wurde die Säule durch Zentrifugation getrocknet. Die Elution erfolgte mit $30 \mu \mathrm{l} 10 \mathrm{mM}$ Tris/HCl pH 8,5.

\subsubsection{Ligation eines DNA-Fragmentes in einen Vektor}

Über Ligation können DNA-Fragmente in einen Vektor integriert werden. Dazu wurden die DNA und der Vektor in getrennten Ansätzen mit den entsprechenden Restriktionsendonukleasen verdaut, mittels Agarosegelelektrophorese aufgetrennt und aus dem Gel isoliert. Der Vektor wurde dabei im Klonierungsabschnitt (multiple cloning site, MCS) geöffnet. Um die Wahrscheinlichkeit des gewünschten Ligationsereignisses zu erhöhen, wurde dem Restriktionsansatz des Vektors Alkalische Phosphatase hinzugefügt. Dadurch wird der Vektor an seinem 5'Terminus dephosphoryliert und kann nun nicht mehr in seiner ursprünglichen Form, sondern nur unter Integration eines fremden Fragmentes ligiert und somit rezikularisiert werden.

Die Ligation des Fragmentes in den Vektor erfolgte nach folgendem Schema:

Ligationsansatz:

$$
\begin{array}{ll}
\mathrm{x} \mu \mathrm{l} & \text { Vektor-DNA } \\
\mathrm{y} \mu \mathrm{l} & \text { DNA-Fragment (3-5 molarer Überschuss) } \\
1 \mu \mathrm{l} & \text { 10x T4-DNA-Ligase-Puffer (400 mM Tris/HCl } \\
& \text { pH 7,8; } 100 \mathrm{mM} \mathrm{MgCl} \text {; } 100 \mathrm{mM} \mathrm{DTT;} 5 \mathrm{mM} \\
& \text { ATP) }
\end{array}
$$




$\begin{aligned} 1 \mu \mathrm{l} & \text { PEG } 4000 \quad(50 \% \quad(\mathrm{w} / \mathrm{v}) ; \text { bei blunt end- } \\ & \text { Ligationen }) \\ \mathrm{z} \mu \mathrm{l} & \begin{array}{l}\text { T4-DNA-Ligase }(1 \mathrm{u} / \mu \mathrm{l} ; 2 \mathrm{u} \text { bei sticky ends, } 5 \mathrm{u} \\ \text { bei blunt ends })\end{array} \\ \text { ad } 10 \mu \mathrm{l} & \mathrm{H}_{2} \mathrm{O} .\end{aligned}$

Die Ligation erfolgte über Nacht bei RT. Anschließend wurde die Ligase durch 15 min Inkubation bei $65^{\circ} \mathrm{C}$ inaktiviert.

\subsubsection{Amplifikation von Plasmid-DNA im Prokaryontensystem}

\subsubsection{Herstellung kompetenter E. coli-Bakterien}

(Qiagen Handbuch: The QIAexpressionist, 2001)

Zunächst wurden $4 \mathrm{ml}$ LB-Medium angeimpft und über Nacht bei $37^{\circ} \mathrm{C}$ im Schüttelinkubator inkubiert. Am nächsten Tag wurden 99 ml LB-Medium mit 1 - 2 $\mathrm{ml}$ der Vorkultur angeimpft und bis zu einer $\mathrm{OD}_{600}$ von 0,4 - 0,6 im Schüttelinkubator bei $37^{\circ} \mathrm{C}$ inkubiert. Diese Bakteriensuspension wurde 10 min auf Eis abgekühlt, in ein JA-20-Röhrchen überführt und danach bei $4^{\circ} \mathrm{C}$ für 5 min bei 4000 x g im JA-20-Rotor zentrifugiert. Das Zellpellet wurde vorsichtig in $30 \mathrm{ml}$ kaltem TFB1-Puffer resuspendiert und 90 min lang auf Eis inkubiert. Nach einem weiteren Zentrifugationsschritt erfolgte die Resuspendierung des Pellets in $4 \mathrm{ml}$ kalten TFB2-Puffer. Diese Zellsuspension wurde in Aliquots von $100 \mu$ und $200 \mu \mathrm{l}$ aufgeteilt, in flüssigem Stickstoff gefroren und bei $-80^{\circ} \mathrm{C}$ gelagert.

TFB1-Puffer: $\quad 100 \mathrm{mM} \mathrm{RbCl,} 50 \mathrm{mM} \mathrm{MnCl}$, $30 \mathrm{mM} \mathrm{KAc}, 10 \mathrm{mM} \mathrm{CaCl}_{2}, 15 \%$ Glycerin, $\mathrm{pH} 5,8$, sterilfiltriert.

TFB2-Puffer: $\quad 10 \mathrm{mM}$ MOPS, $10 \mathrm{mM} \mathrm{RbCl}, 75 \mathrm{mM} \mathrm{CaCl}_{2}, 15 \%$ Glycerin, mit $\mathrm{KOH}$ auf pH 6,8 eingestellt, sterilfiltriert. 


\subsubsection{Transformation kompetenter $E$. coli-Bakterien mit Plasmid-DNA durch Hitzeschockbehandlung}

$50 \mu$ l kompetente E. coli XL-Blue wurden auf Eis aufgetaut, mit Plasmid-DNA (z.B. nach Ligation, siehe Seite 30) versetzt und 15 min auf Eis inkubiert, um eine Anlagerung der DNA an die Zelloberfläche zu ermöglichen. Anschließend wurde der Ansatz einem Hitzeschock von 1,5 min bei $42^{\circ} \mathrm{C}$ unterzogen und 2 min auf Eis wieder abgekühlt. Nach Zugabe von $500 \mu$ LB-Medium wurde der Transformationsansatz für $30 \mathrm{~min}$ im Schüttelinkubator bei $37^{\circ} \mathrm{C}$ inkubiert. In dieser Phase wurde die während des Hitzeschocks aufgenommene DNA exprimiert und somit die auf dem Plasmid codierte Antibiotika-Resistenz ausgebildet. Dann erfolgte eine Zentrifugation für $1 \mathrm{~min}$ bei $10.000 \times \mathrm{g}$. Das Zellpellet wurde in $200 \mu \mathrm{l}$ LB-Medium resuspendiert und (entsprechend dem Resistenzgen des Plasmids) auf einer Ampicillin-haltigen LB-Agarplatte ausplattiert. Für eine Blau-Weiß-Selektion wurden auf der Platte zuvor $20 \mu$ IPTG (Isopropyl-b-D-Thiogalaktopyranosid; $100 \mathrm{mM}$ in $\mathrm{H}_{2} \mathrm{O}$ ) und $40 \mu \mathrm{l}$ X-Gal (4 \% in N'N'-Dimethylformamid) ausgestrichen.

Die Platte wurde über Nacht bei $37^{\circ} \mathrm{C}$ im Brutschrank inkubiert. Mit den darauf gewachsenen weißen Kolonien wurden jeweils $4 \mathrm{ml}$ LB-Medium mit $200 \mu \mathrm{g} / \mathrm{ml}$ Ampicillin angeimpft.

\subsubsection{Mini-Präparation von Plasmid-DNA aus E. coli-Bakterien} (QIAprep Miniprep Handbuch, 1999)

Lösungen: Die Zusammensetzung der Puffer wird von Qiagen nicht angegeben. $4 \mathrm{ml}$ LB-Medium mit $200 \mu \mathrm{g} / \mathrm{ml}$ Ampicillin wurden mit einer transformierten E. coliKolonie angeimpft und über Nacht im Schüttelinkubator bei $37^{\circ} \mathrm{C}$ inkubiert. Die Bakteriensuspension wurde $1 \mathrm{~min}$ in der Eppendorfzentrifuge bei $10000 \mathrm{rpm}$ zentrifugiert. Das Zellpellet wurde in $250 \mu \mathrm{l}$ kaltem P1-Puffer resuspendiert, mit $250 \mu \mathrm{l}$ P2-Puffer lysiert und mit $350 \mu \mathrm{l}$ N3-Puffer neutralisiert.

Darauf folgte eine Zentrifugation bei 13000 rpm für $10 \mathrm{~min}$. Der Überstand wurde auf eine QIAprep-Säule gegeben und eine Minute bei 13000 rpm zentrifugiert. Der Durchfluss wurde verworfen, die Säule mit $750 \mu$ l PE-Puffer gewaschen und 
anschließend durch Zentrifugation getrocknet. Die Elution der gebundenen DNA erfolgte mit $50 \mu \mathrm{l} \mathrm{H}_{2} \mathrm{O}$.

\subsubsection{Midi-Präparation von Plasmid-DNA aus E. coli-Bakterien}

(QIAprep Midiprep Handbuch, 1999)

Es wurden $100 \mathrm{ml}$ einer Bakterienkultur bei $6000 \times \mathrm{g}$ im JA-10-Rotor abzentrifugiert. Das Zellpellet wurde in $4 \mathrm{ml} \mathrm{P1}$ resuspendiert, in JA-20-Röhrchen überführt, mit $4 \mathrm{ml} \mathrm{P2}$ versetzt, vorsichtig durch Rollen gemischt und 5 min bei RT inkubiert. Durch Zugabe von $4 \mathrm{ml}$ kaltem P3 wurde neutralisiert und anschließend 15 min auf Eis inkubiert.

Die Suspension wurde $30 \mathrm{~min}$ im JA-20-Rotor bei $20000 \mathrm{xg}$ und $4^{\circ} \mathrm{C}$ zentrifugiert, der Überstand abgenommen und erneut 15 min zentrifugiert. Der Überstand wurde auf eine mit $4 \mathrm{ml}$ QBT-Puffer äquilibrierte Qiagen-100-Säule gegeben. Die Plasmid-DNA bindet an das Silikagel-Anionenaustauscher-Säulenmaterial. Die Säule wurde zweimal mit $10 \mathrm{ml}$ QC-Puffer gewaschen, die Plasmid-DNA anschließend mit $5 \mathrm{ml}$ QF-Puffer eluiert und in einem 50-ml-Röhrchen aufgefangen. Die DNA wurde mit 3,5 ml Isopropanol gefällt und bei $5000 \mathrm{rpm}$ und $4^{\circ} \mathrm{C}$ in der Labofuge für 45 min zentrifugiert. Das weiße Pellet wurde zweimal mit je $2 \mathrm{ml} \mathrm{70 \% igem} \mathrm{Ethanol} \mathrm{gewaschen,} \mathrm{bei} \mathrm{RT} \mathrm{getrocknet} \mathrm{und} \mathrm{in} \mathrm{einem} \mathrm{geeigneten}$ Volumen $\mathrm{ddH}_{2} \mathrm{O}$ aufgenommen.

P1: $\begin{aligned} 50 \mathrm{mM} & \text { Tris/HCl, } \mathrm{pH} 8,0 \\ 10 \mathrm{mM} & \text { EDTA } \\ 100 \mu \mathrm{g} / \mathrm{ml} & \text { RNase A. }\end{aligned}$

P2: $\quad \begin{array}{rl}0,2 \mathrm{M} & \mathrm{NaOH} \\ 1 \% & \text { SDS. }\end{array}$

P3: $\quad 3 \mathrm{M} \quad \mathrm{KAc}, \mathrm{pH} 5,5$.

QBT-Puffer: $\quad 750 \mathrm{mM} \quad \mathrm{NaCl}$ 


$\begin{array}{lrl} & 50 \mathrm{mM} & \text { MOPS, pH 7,0 } \\ & 15 \% & \text { Ethanol } \\ & 0,15 \% & \text { Triton X-100. } \\ \text { QC-Puffer: } & 1,0 \mathrm{M} & \mathrm{NaCl} \\ & 50 \mathrm{mM} & \text { MOPS, pH 7,0 } \\ & 15 \% & \text { Ethanol. } \\ & & \\ \text { QF-Puffer: } & 1,25 \mathrm{M} & \mathrm{NaCl} \\ & 50 \mathrm{mM} & \text { Tris/HCl, pH 8,5 } \\ & 15 \% & \text { Ethanol. }\end{array}$

\subsubsection{Isolierung genomischer DNA aus embryonalen Stammzellen}

Die Zellen wurden von den Zellkulturplatten abgeschabt, pelletiert und in $0,3 \mathrm{ml}$ Lysispuffer überführt. Dieser Ansatz wurde mit $30 \mu \mathrm{l}$ frisch angesetzter Proteinase K-Stammlösung (10 mg/ml Proteinase $\mathrm{K}$ in Lysispuffer) versetzt und über Nacht bei $56^{\circ} \mathrm{C}$ im Schüttelwasserbad inkubiert. Die Proteinase $K$ sorgte für die Inaktivierung endogener Nukleasen, so dass die DNA intakt blieb. Nach 15 min Zentrifugation bei 13000 rpm in der Eppendorf-Zentrifuge wurde zum Überstand 1 $\mathrm{ml}$ Ethanol gegeben. Die dabei ausgefallene DNA wurde mit einer Glaspipette mit abgerundeter Spitze aufgenommen, in 70\%igem Ethanol gewaschen, bei RT getrocknet und danach in $200 \mu \mathrm{l}$ Wasser gelöst und bis zur weiteren Verwendung bei $4^{\circ} \mathrm{C}$ gelagert.

$\begin{array}{lrl}\text { Lysispuffer: } & 50 \mathrm{mM} & \text { Tris, pH 8,0 } \\ 50 \mathrm{mM} & \text { EDTA } \\ 100 \mathrm{mM} & \mathrm{NaCl} \\ 0,5 \% & \text { SDS. }\end{array}$




\subsubsection{Präzipitation von DNA mit Ethanol}

Nach Bestimmung des Volumens der DNA-Lösung wurden entsprechend 1/5 des Volumens 3M NaAc-Lösung ( $\mathrm{pH} \mathrm{5,2)} \mathrm{zugefügt.} \mathrm{Dies} \mathrm{dient} \mathrm{der} \mathrm{Bereitstellung} \mathrm{der}$ zur Präzipitation erforderlichen Kationen. Zudem wurde 100\%iges Ethanol im Fünffachen des Ausgangsvolumens dazu gegeben und gemischt. Die DNA wurde durch 20 min Zentrifugation pelletiert. Anschließend wurde mit 70\%igem Ethanol gewaschen und erneut 20 min zentrifugiert. Das Präzipitat wurde nach der Trocknung bei RT je nach gewünschter Konzentration in einem entsprechenden Volumen TE-Puffer oder $\mathrm{H}_{2} \mathrm{O}$ aufgenommen.

\subsubsection{Markierung einer DNA-Sonde mit $\alpha-\left[{ }^{32} \mathrm{P}\right] \mathrm{dCTP}$}

$25 \mathrm{ng}$ der zu markierenden DNA-Sequenz wurden in $45 \mu \mathrm{l} \mathrm{H}_{2} \mathrm{O}$ verdünnt, 5 min bei $95^{\circ} \mathrm{C}$ denaturiert, auf Eis abgekühlt und zu einem Aliquot des RediPrime II Labeling Lyophilisats (Amersham Pharmacia) gegeben, welches vorsichtig darin gelöst wurde. Auf die Zugabe von $5 \mu l{ }^{32} \mathrm{P}$-dCTP $(50 \mu \mathrm{Ci})$ folgten $15 \mathrm{~min}$ Inkubation bei $37^{\circ} \mathrm{C}$. Um die markierte Sonde von freien Nukleotiden zu trennen, erfolgte eine Aufreinigung über eine QIAquick-Mini-Säule. Dazu wurde der Ansatz mit $250 \mu \mathrm{l}$ PN-Puffer versetzt auf eine QIAquick-Mini-Säule gegeben. Darauf folgten eine kurze Zentrifugation, zwei Waschschritte mit jeweils $500 \mu \mathrm{l}$ PE-Puffer und die Elution der Sonde mit $200 \mu$ EB-Puffer.

\subsubsection{Transfer von DNA auf Hybond N-Filter (Southern-Blot)} (Southern, 1975; Alwine et al., 1977)

Nach einem geeigneten Restriktionsverdau und der Auftrennung im Agarosegel wurde die zu analysierende DNA denaturiert. Dazu wurde das Gel zweimal 15 min in Denaturierungs-Lösung und anschließend zweimal $15 \mathrm{~min}$ in NeutralisierungsLösung auf einem Wipptisch geschwenkt. Nach 10 min Äquilibrieren in 20x SSC erfolgte der Transfer über Nacht mit 20x SSC als Transferpuffer mit dem in Abb. 4 dargestellten Aufbau. Der Pfeil zeigt die Richtung des Flüssigkeitsstromes an, 
durch den die DNA aus dem Agarosegel auf den darüberliegenden Hybond-NylonFilter (Membran) übertragen wird.

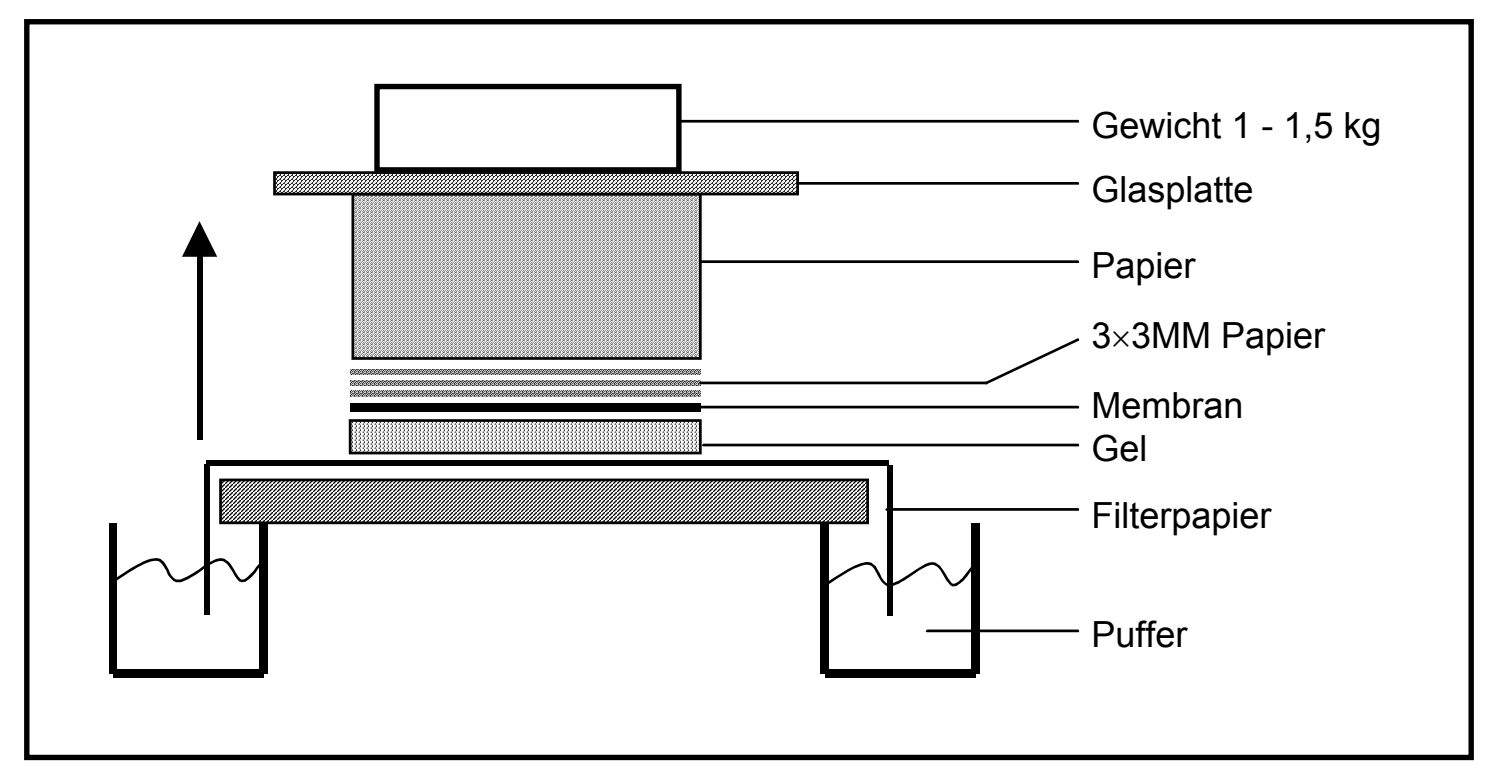

Abb. 4: $\quad$ Transfer von Nukleinsäuren aus Agarosegelen auf Hybond N-Filter.

Der Filter wurde im Wärmeschrank bei $37^{\circ} \mathrm{C}$ getrocknet und die DNA-Seite markiert. Durch 15 Sekunden UV-Bestrahlung $(260 \mathrm{~nm})$ der DNA-Seite auf dem UV-Transilluminator wurde die DNA fest an die Filteroberfläche gebunden.

$\begin{array}{lll}\text { Denaturierungs-Lösung: } & 1,5 \mathrm{M} & \mathrm{NaCl} \\ & 0,5 \mathrm{M} & \mathrm{NaOH} . \\ \text { Neutralisierungs-Lösung: } & 1,5 \mathrm{M} & \mathrm{NaCl} \\ & 0,5 \mathrm{M} & \text { Tris/HCl, pH 7,2 } \\ & 1 \mathrm{mM} & \text { EDTA. }\end{array}$




\subsubsection{Hybridisierung von Southern-Blots mit radioaktiv markierten Sonden}

Zur Hybridisierung wurde der Filter mit dem Hybridisierungsmix $\left(1 \mathrm{ml} / 10 \mathrm{~cm}^{2}\right)$ in einem Plastikröhrchen vorinkubiert. Nach ca. 10 min wurde die radioaktiv markierte DNA-Sonde, die vorher zusammen mit der Lachssperma-DNA (Endkonzentration $100 \mu \mathrm{g} / \mathrm{ml}$ ) $5 \mathrm{~min}$ bei $95^{\circ} \mathrm{C}$ denaturiert worden war, zum Filter in den Hybridisierungsmix pipettiert. Es wurden $1-2 \times 10^{6} \mathrm{cpm}$ DNA-Sonde/ml Hybridisierungsmix eingesetzt.

Der Filter wurde über Nacht in der Hybridisierungslösung bei $42^{\circ} \mathrm{C}$ inkubiert, indem das Plastikröhrchen im Wärmeschrank gerollt wurden.

Anschließend wurde der Filter aus dem Röhrchen mit der radioaktiven Hybridisierungslösung genommen und zunächst mit 2x SSC / 0,1\% SDS 10 min bei RT, dann mehrfach mit 0,2x SSC / $0,1 \%$ SDS $10 \mathrm{~min}$ bei $65^{\circ} \mathrm{C}$ im Schüttelwasserbad gewaschen, bis mit dem Handcounter nach Möglichkeit weniger als $40 \mathrm{cpm}$ messbar waren.

Der Filter wurde feucht in Folie eingeschweißt und mit einem PhosphoimagerScreen und einem Kodak-XAR-5-Röntgenfilm autoradiographiert.

Lachssperma-DNA: Die Lachssperma-DNA wurde mit einer sterilen Schere zerkleinert und in $\mathrm{H}_{2} \mathrm{O}$ gelöst $(10 \mathrm{mg} / \mathrm{ml})$. Nach $10 \mathrm{~min}$ Ultraschallbehandlung wurde die Lösung in der Mikrowelle aufgekocht und nochmals mit Ultraschall behandelt. Die so gelöste DNA wurde in 2-ml-Aliquots bei $-20^{\circ} \mathrm{C}$ gelagert.

$\begin{array}{rrl}\text { Hybridisierungsmix: } & 72 \mathrm{ml} & \text { Formamid } \\ 36 \mathrm{ml} & 20 x \text { SSC } \\ 1,5 \mathrm{ml} & \text { Tris/HCl 1 M, pH 7,5 } \\ 1,5 \mathrm{~g} & \text { SDS } \\ 3 \mathrm{ml} & 50 x \text { Denhardts } \\ 30 \mathrm{ml} & 50 \% \text { iges Dextransulfat. }\end{array}$


$15 \mathrm{~g}$ Dextransulfat wurden mit $\mathrm{H}_{2} \mathrm{O}$ auf $30 \mathrm{ml}$ aufgefüllt und bei $80^{\circ} \mathrm{C}$ gelöst. Anschließend wurden die anderen Substanzen zugesetzt und das Volumen mit $\mathrm{H}_{2} \mathrm{O}$ auf $150 \mathrm{ml}$ aufgefüllt. Die Lagerung erfolgte bei $4^{\circ} \mathrm{C}$.

\subsubsection{Polymerase-Ketten-Reaktion}

(Saiki et al., 1986; Saiki et al., 1988)

Die Polymerase-Ketten-Reaktion (PCR) ist eine Methode, mit der definierte DNABereiche amplifiziert werden können. Sie basiert auf drei Schritten, die für die Synthese der DNA notwendig sind:

1) Denaturierung der Ausgangs-DNA (Template) in Einzelstränge

2) Annealing: Bindung von Oligonukleotiden (Primer) an beide Einzelstränge

3) Extension/Elongation: Synthese der DNA durch die Polymerase, ausgehend von den gebundenen Primern

Auswahl und Konzentration der Primer, Qualität (genomisch, Plasmid, lineares

Fragment) und Menge des Templates, Pufferbedingungen, Zeiten und

Temperaturen der einzelnen Zyklusschritte beeinflussen die Synthese der DNA.

\subsubsection{Primer-Design}

(Qiagen Handbuch: HotStar-Taq-PCR , 1999)

Das Design von Primer-Paaren ist für die PCR von entscheidender Bedeutung und wurde nach folgenden Grundregeln durchgeführt: Die Länge eines Primers sollte zwischen 17 und 27 Basen liegen. Die Schmelztemperaturen $T_{m}$ beider Primer eines Primer-Paares sollten nach Möglichkeit identisch sein. Die Kenntnis von $T_{m}$ ist für die Festlegung der Annealing-Temperatur $T_{a n n}$, bei der ein Primer spezifisch mit einer DNA-Matrize hybridisiert, notwendig. $\mathrm{T}_{\mathrm{m}}$ eines Primers in einer PCR ist von den Salz- und Tris-HCl-Konzentrationen im Reaktionspuffer sowie von der Länge, der Konzentration und der Sequenz des Primers abhängig. Als Faustregel zur vereinfachten Berechnung diente folgende Formel: 


$$
\mathrm{T}_{\mathrm{m}}=4 \times(\mathrm{G}+\mathrm{C})+2 \times(\mathrm{A}+\mathrm{T})
$$

Dabei stehen $G, C, A$ und $T$ für die Anzahl der jeweiligen Base im Primer.

$\mathrm{T}_{\text {ann }}$ sollte 5 bis $10^{\circ} \mathrm{C}$ unter $T_{m}$ liegen und die Synthesetemperatur der verwendeten, thermostabilen DNA-Polymerase $\left(68-72^{\circ} \mathrm{C}\right)$ nicht überschreiten.

Weiterhin ist bei dem Design von Primern zu beachten, dass Dimerisierungen durch komplementäre Sequenzen innerhalb eines Primers oder eines PrimerPaares zu vermeiden sind und die Termini zur stabileren Matrix-Bindung möglichst aus einem oder zwei $\mathrm{G}$ oder $\mathrm{C}$ bestehen sollten.

\subsubsection{Standard-PCR}

Standard-PCR-Anwendungen wurden nach Protokollen aus dem Handbuch von McPherson et al. (1991) durchgeführt. Soweit nicht anders erwähnt, erfolgten die Reaktionen in einem Gesamtvolumen von 50 oder $100 \mu$ l. Ein Standard-PCRAnsatz setzte sich folgendermaßen zusammen:

$$
\begin{aligned}
\text { x ng } & \text { Template-DNA } \\
250 \mathrm{nM} & \text { sense(5')-Primer } \\
250 \mathrm{nM} & \text { antisense(3')-Primer } \\
\text { jeweils } 0,2 \mathrm{mM} & \text { dNTPs } \\
1 \mathrm{x} & \text { Reaktionspuffer } \\
0,025 \mathrm{u} / \mu \mathrm{l} & \text { Taq-DNA-Polymerase. }
\end{aligned}
$$

Die eingesetzte DNA-Menge variierte, lag aber üblicherweise im Bereich zwischen 50 und $100 \mathrm{ng}$. 
Als Thermocycler-Programm wurden folgende Temperaturen und Zeiten gewählt:

\begin{tabular}{|c|c|c|c|}
\hline $1 \mathrm{~min}$ & $94^{\circ} \mathrm{C}$ & & \\
\hline $0,5 \mathrm{~min}$ & $94^{\circ} \mathrm{C}$ & & Denaturierung der DNA \\
\hline $0,5 \mathrm{~min}$ & $55^{\circ} \mathrm{C}$ & $30-35 x$ & Annealing der Primer \\
\hline $1 \mathrm{~min}$ pro $\mathrm{kb}+2 \mathrm{~min}$ & $72^{\circ} \mathrm{C}$ & & Elongation \\
\hline $10 \mathrm{~min}$ & $72^{\circ} \mathrm{C}$ & & finale Elongation \\
\hline & $4^{\circ} \mathrm{C}$ & & \\
\hline
\end{tabular}

\subsubsection{PCR mit dem AccuPrime ${ }^{\mathrm{TM}}$-Taq-DNA-Polymerase-System und dem HotStar-Taq-DNA-Polymerase-System}

Das AccuPrime ${ }^{\mathrm{TM}}$-Taq-DNA-Polymerase-System eignet sich erfahrungsgemäß besonders gut für die Amplifikation von Fragmenten mit genomischer TemplateDNA.

Die HotStar-Taq-DNA-Polymerase benötigt einen initialen Aktivierungsschritt von 15 min bei $95^{\circ} \mathrm{C}$ und eignet sich daher nicht für Amplifikationen von genomischer Template-DNA. Durch die beigefügte Q-Solution (Zusammensetzung wird nicht angegeben) wird jedoch eine äußerst effektive und spezifische Amplifikation erzielt.

Der Ansatz und das Thermocycler-Programm wurden jeweils nach Angaben der Hersteller gestaltet.

\subsubsection{In-vitro-Mutagenese mit dem QuikChange ${ }^{\mathrm{TM}}$ Site-Directed Mutagenesis Kit}

(QuikChange $^{\mathrm{TM}}$ Site-Directed Mutagenesis Kit Instruction Manual, Stratagene, 1996)

Mit Hilfe der in-vitro-Mutagenese können ortsspezifisch Punktmutationen oder Deletionen in DNA-Sequenzen erzeugt werden, die zu einem gezielten Austausch von Aminosäuren oder zur Einführung neuer Restriktionsschnittstellen bzw. deren Entfernung führen. 
Die Replikation der DNA-Matrize, in die die Mutation eingeführt werden soll, wird von der PfuTurbo ${ }^{\circledR}$-DNA-Polymerase katalysiert, deren Proofreading-Aktivität die geringste Fehlerrate aller bekannten thermostabilen Polymerasen gewährleistet.

Die einzusetzenden Primer müssen die gewünschte Mutation mittig beinhalten und genau zueinander komplementär sein.

Der Ansatz und das Thermocycler-Programm wurden analog zur Standard-PCR und gemäß der Angaben des Herstellers gestaltet.

Nach Ablauf der Reaktion und Abkühlen des Ansatzes wurde diesem $1 \mu \mathrm{l}$ des Restriktionsenzyms $D p n$ I (10u/ $\mu \mathrm{l})$ zugesetzt, welches die parentale, nicht-mutierte und methylierte DNA verdaute, während die neu synthetisierte, mutierte und nichtmethylierte DNA unverdaut blieb. Der Verdau erfolgte für eine Stunde bei $37^{\circ} \mathrm{C}$.

Direkt nach dem Verdau erfolgte mit $5 \mu$ des Ansatzes eine Transformation von kompetenten E. coli-Zellen, welche die DNA wieder zirkularisieren und amplifizieren. Die resultierende Plasmid-DNA konnte nun isoliert werden und der Erfolg der Mutagenese gegebenenfalls durch Sequenzierung oder einen geeigneten Restriktionsverdau überprüft werden.

\subsubsection{Sequenzierung von DNA}

Für die Sequenzierung von DNA-Abschnitten wurde zunächst mit dem ABI PRISM Dye Terminator Cycle Sequencing Ready Reaction Kit nach Protokoll des Herstellers eine spezielle PCR durchgeführt. Als Template dienten entweder PCRProdukte oder Plasmid-DNA. Das PCR-Produkt wurde mittels Ethanol-Fällung aufgereinigt, in $25 \mu \mathrm{l} \mathrm{H}_{2} \mathrm{O}$ aufgenommen und in einem kapillarelektrophoretischen Verfahren in einem DNA-Sequenzer automatisch sequenziert. 


\subsection{Methoden zur Arbeit mit eukaryontischen Zellen}

\subsubsection{Gelatinisieren der Flaschen und Platten}

Die zuvor sterilisierte Gelatine (1\%) wurde mit PBS 1:10 verdünnt und auf die Gewebekulturschalen oder -flaschen gegeben, so dass der Boden bedeckt war. Nach einer Inkubation von mindestens zwei Stunden bei RT wurden die Fibroblasten nach Absaugen der Gelatine auf die Schalen oder Flaschen gegeben.

\subsubsection{Trypsinieren von Zellen}

Nach Absaugen des Mediums von der Gewebekulturschale wurden die Zellen einmal mit PBS gewaschen. Anschließend wurden sie 15 min mit Trypsin-EDTA 0,25\% inkubiert, Fibroblasten hingegen nur 5 min mit Trypsin-EDTA 0.05\%. Die Reaktion wurde durch Zugabe von einem entsprechenden Medium gestoppt, die Zellen resuspendiert und in der gewünschten Dichte auf neue gelatinisierte Gewebekulturschalen ausgesät.

\subsubsection{Präparation von primären Neo-resistenten Fibroblasten}

Eine trächtige Maus (Tag 12-13 p.c.) wurde schmerzfrei getötet. Das Abdomen wurde eröffnet, der Uterus wurde freipräpariert, entnommen und in einer Petrischale mit PBS gewaschen. Die Embryonen wurden aus Uterus und Amnionhöhle herausgelöst und mit PBS gewaschen. Der Kopf wurde abgetrennt, Herz und Leber wurden entfernt. Die Embryonen wurde zerschnitten und wiederum in PBS gespült.

Das Embryonengewebe wurde in einem sterilen Erlenmeyerkolben mit $25 \mathrm{ml}$ 0,25\%igem Trypsin und sterilen Glasperlen $(\varnothing 4-5 \mathrm{~mm}) 15 \mathrm{~min}$ bei $37^{\circ} \mathrm{C}$ gerührt, die Trypsinierung durch Zugabe von $25 \mathrm{ml}$ DMEM gestoppt und der Ansatz durch ein Embryonensieb in ein 50-ml-Plastikröhrchen filtriert. Die Zellen wurden 
pelletiert, in DMEM resuspendiert, auf 10-cm-Gewebekulturschalen ausgesät und kultiviert. Diese und alle weiteren benutzten Gewebekulturschalen wurden vor der Benutzung gelatinisiert.

Medium für Maus-Embryonen-Fibroblasten (MEF; "Feeder-Zellen"):

$500 \mathrm{ml} \quad$ DMEM (Knock-Out DMEM)

$6 \mathrm{ml} \quad$ MEM non-essential amino acids (100x)

$6 \mathrm{ml} \quad$ L-Glutamin (100x)

$3 \mathrm{ml} \quad$ Penicillin/Streptomycin (100x)

$6 \mathrm{ml} \quad$ B-Mercaptoethanol (7,2 $\mu \mathrm{l}$ von $14 \mathrm{M} \mathrm{Lsg}$. in $10 \mathrm{ml}$ PBS)

$\rightarrow$ diese Lösung vor FKS-Zugabe sterilfiltrieren $(0,20 \mu \mathrm{m})$

$95 \mathrm{ml} \quad$ FKS (entspr. $15 \%$ ).

\subsubsection{Mitotische Inaktivierung von Fibroblasten}

Konfluente Mausfibroblasten wurden vor Benutzung als Feederzellen durch Behandlung mit dem Zytostatikum Mitomycin C mitotisch inaktiviert. Dazu wurde dem Medium in 1:100-Verdünnung Mitomycin $C$ zugesetzt. Nach einer Inkubation über $2,5 \mathrm{~h}$ bei $37^{\circ} \mathrm{C}$ wurde das Medium abgesaugt. Die Zellen wurden dreimal mit PBS gewaschen, trypsiniert und auf neue Gewebekulturschalen ausgesät.

Während einer mindestens 2-stündigen Inkubationszeit setzen sich die mitotisch inaktiven Zellen ab und bilden einen geschlossenen Zellrasen, auf dem ES-Zellen kultiviert werden konnten.

\subsubsection{Kultivierung von embryonalen Stammzellen}

Sämtliche Methoden lehnen sich an Protokolle an, wie sie in "Teratocarcinomas and Embyonic Stem Cells" (Robertson, 1987), "Gene Targeting" (Joyner, 1993), "Manipulating the Mouse Embryo" (Hogan et al., 1994) und "Gene targeting by Homologous Recombination in Embryonic Stem Cells" (Mansouri, 1998) beschrieben sind. 
Die embryonalen Stammzellen (ES-Zellen) wurden in wassergesättigter Atmosphäre unter $5 \% \mathrm{CO}_{2}$ bei $37^{\circ} \mathrm{C}$ auf einem Rasen aus mitotisch inaktivierten Maus-Embryonen-Fibroblasten (MEF; "Feeder-Zellen") kultiviert. Medien und Lösungen wurden auf $37^{\circ} \mathrm{C}$ vorgewärmt, wenn nicht anders angegeben.

Die Arbeiten mit ES-Zellen wurden in einem separaten Zellkulturlabor ausgeführt; es wurde stets mit Kittel und Handschuhen gearbeitet, um die Wahrscheinlichkeit von Infektionen zu senken. Alle Arbeiten wurden mit Einweg-Plastikmaterial (Pipetten, Plastikröhrchen, Gewebekulturschalen) durchgeführt.

Die Zellen wuchsen in abgerundeten, gut abgrenzbaren Kolonien und wurden täglich mikroskopisch kontrolliert. Je nach Ansäuerung durch die ES-Zellen wurde das Medium gewechselt. Diesem wurde u.a. LIF (Leukemia Inhibitor Factor) zugesetzt, welcher eine Differenzierung der ES-Zellen verhinderte.

Eine erneute Passagierung wurde, je nach Dichte der Zellen, alle zwei bis vier Tage durchgeführt. Für optimale Ergebnisse mussten sich die ES-Zellen zum Zeitpunkt von Passagierung, Kryokonservierung oder Elektroporation noch im exponentiellen Wachstum (bis zu 80 \% Konfluenz) befinden.

Alle Zentrifugationsschritte erfolgten, soweit nicht anders angegeben, für $7 \mathrm{~min}$ bei 1000 rpm in der Labofuge.

Medium für ES-Zellen:

$500 \mathrm{ml} \quad$ DMEM (Knock-Out DMEM)

$6 \mathrm{ml} \quad$ MEM non-essential amino acids (100x)

$6 \mathrm{ml} \quad$ L-Glutamin (100x)

$3 \mathrm{ml} \quad$ Penicillin/Streptomycin (100x)

$6 \mathrm{ml} \quad$ B-Mercaptoethanol (7,2 $\mu \mathrm{l}$ von $14 \mathrm{M} \mathrm{Lsg}$. in $10 \mathrm{ml}$ PBS)

$65 \mu \mathrm{l} \quad$ LIF (Chemicon ESGRO ESG1107)

$\rightarrow$ diese Lösung vor FKS-Zugabe sterilfiltrieren $(0,22 \mu \mathrm{m})$

$95 \mathrm{ml} \quad$ FKS (entspr. 15\%; Hyclone, ES-Cell-tested; steril, nicht hitzeinaktiviert). 


\subsubsection{Kryokonservierung von Zellen}

Die Zellen wurden mit PBS gewaschen, trypsiniert und im gewünschten Volumen ES-Medium aufgenommen. Nun wurde tropfenweise unter leichtem Schütteln dieselbe Menge Einfriermedium zugefügt. Die Zellsuspension wurde in ein Kryoröhrchen gefült, stufenweise auf $-80^{\circ} \mathrm{C}$ über Nacht abgekühlt und am nächsten Tag in flüssigen Stickstoff überführt.

$\begin{array}{lll}\text { Einfriermedium: } & 60 \% & \text { DMEM } \\ & 20 \% & \text { FKS } \\ & 20 \% & \text { DMSO. }\end{array}$

\subsubsection{Revitalisierung von Zellen}

Nach der Entnahme des Kryoröhrchens aus dem Stickstoff-Tank wurde es für 1 min bei RT angewärmt und dann im $37^{\circ} \mathrm{C}$-Ethanolbad unter Schwenken aufgetaut bis nur noch ein kleiner Eiskern vorhanden war. Nun wurde tropfenweise das 3bis 5-fache Volumen an ES-Medium zugeben und ausplattiert. Am nächsten Tag erfolgte ein Mediumwechsel, um die für die Zellwand schädlichen DMSO-Reste zu entfernen.

\subsubsection{DNA-Transfer in ES-Zellen durch Elektroporation}

Die ES-Zellen von 2 konfluenten 10-cm-Gewebekulturschalen wurden mit PBS gewaschen, trypsiniert, mit Medium resuspendiert, $7 \mathrm{~min}$ bei $1000 \mathrm{rpm}$ abzentrifugiert und erneut in PBS aufgenommen. $800 \mu \mathrm{l}$ der Zellsuspension wurden in eine sterile Elektroporationsküvette (4 $\mathrm{mm}$ Elektrodenabstand) gegeben. 20-25 $\mu \mathrm{g}$ linearisierte DNA (Rekombinationskonstrukt) in EB-Puffer wurden der Zellsuspension zugesetzt und der Ansatz gemischt.

Nun wurde eine Kapazität von $500 \mu \mathrm{F}$ bei einer Spannung von $240 \mathrm{~V}$ über die Elektroporationsküvette durch die Zell/DNA-Suspension entladen. Durch Einwirkung eines solchen kurzen elektrischen Impulses oberhalb einer kritischen 
Feldstärke werden biologische Membranen vorübergehend permeabilisiert, ohne dass die Membranstruktur zerstört wird. Während der Phase erhöhter Durchlässigkeit konnte das Rekombinationskonstrukt in die ES-Zellen eindringen.

Die Zellen wurden nach dem Strompuls für $10 \mathrm{~min}$ bei RT stehengelassen, dann in ES-Medium aufgenommen und auf zwei vorbereitete 15-cm-Feederplatten verteilt. Als Negativ-Kontrolle wurden die ES-Zellen einer weiteren 10-cm-Platte ohne Zugabe von DNA elektroporiert.

\subsubsection{Selektion von ES-Zell-Klonen nach Elektroporation}

Transfizierte Zellen wurden $24 \mathrm{~h}$ nach der Elektroporation auf G418 (Geneticin®)Resistenz selektiert, die bei erfolgreicher Rekombination durch die im Rekombinationskonstrukt enthaltene Neo-Kassette vermittelt wurde.

Dem ES-Medium wurde zu diesem Zweck $335 \mu \mathrm{g} / \mathrm{ml}$ G418 zugesetzt. Die Selektion wurde bis zur Isolierung von Einzelklonen nach 10 Tagen aufrechterhalten.

\subsubsection{Isolierung von ES-Zell-Einzelklonen}

Das Medium der Selektionsschalen wurde abgesaugt, die Zellen einmal mit PBS gewaschen und mit $10 \mathrm{ml}$ PBS bedeckt. Unter dem Mikroskop wurden die Klone

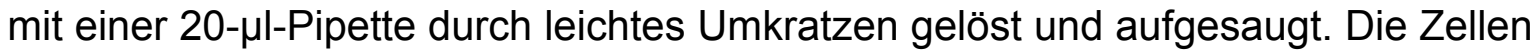
eines Klons wurden in 0,25 \%igem Trypsin-EDTA überführt, 15 min bei $37^{\circ} \mathrm{C}$ inkubiert und durch mehrmaliges Aufziehen mit einer Pipette vereinzelt. Die Zellsuspension wurde in ein Loch einer mit einem Feederrasen bedeckten 12Loch-Gewebekulturplatte gegeben.

Die ES-Zellen wurden bis zur Konfluenz kultiviert, durch Trypsinieren geerntet und der größte Teil eines jeden Loches kryokonserviert. Der geringe übriggebliebene Teil der Zellen wurde auf der Platte belassen, mit neuem Medium versetzt und nach erneuter Konfluenz der Zellen die genomische DNA isoliert. Mit Hilfe von Southernblot-Analysen und PCR wurde auf homologe Rekombinationsereignisse hin untersucht. 


\subsubsection{Ausschneiden der gefloxten Neo-Kassette}

Im Rahmen dieser Arbeit wurde eine Neo-Kassette, die von zwei loxP-Sequenzen eingeschlossen war (gefloxt), als Selektionsmarker verwendet. Dies ermöglicht es, den Selektionsmarker schon vor der Mikroinjektion aus den homologen rekombinanten ES-Zellen wieder zu entfernen. Mit Hilfe der Elektroporation wurden $30 \mu \mathrm{g}$ eines Cre-Rekombinase-Gen enthaltenden Plasmides in die ESZellen gebracht. Eine anschließende Selektion ist nicht mehr möglich. Mit Southernblot-Analysen oder PCR konnten die Zellen erneut überprüft werden.

\subsubsection{Vorbereitung von ES-Zellen für die Mikroinjektion}

Als Vorbereitung für die Mikroinjektion der ausgewählten ES-Zell-Klone wurden diese auf einer dünn bewachsenen 6-cm-Platte einmal mit PBS gewaschen. Nach dem Trypsinieren wurden sie in $5 \mathrm{ml}$ ES-Medium resuspendiert und $15 \mathrm{~min}$ auf der Platte bei $37^{\circ} \mathrm{C}$ ruhig stehen gelassen. In dieser Zeit setzten sich die schwereren Fibroblasten auf den Boden ab. Die leichteren ES-Zellen wurden anschließend mit dem Überstand in ein 15-ml-Plastikröhrchen überführt. 


\section{$3 \quad$ Ergebnisse}

\subsection{Generierung der Gene-Targeting-Vektoren (GTV)}

Das murine Gen Pmm2 besitzt eine Größe von $20 \mathrm{~kb}$ und umfasst acht Exons. Es kodiert für ein Protein mit einer Größe von 258 Aminosäuren. Zur einfacheren Handhabung wurden Zwischenprodukte des GTV in einen pBlueScript-Vektor (pBSK) subkloniert.

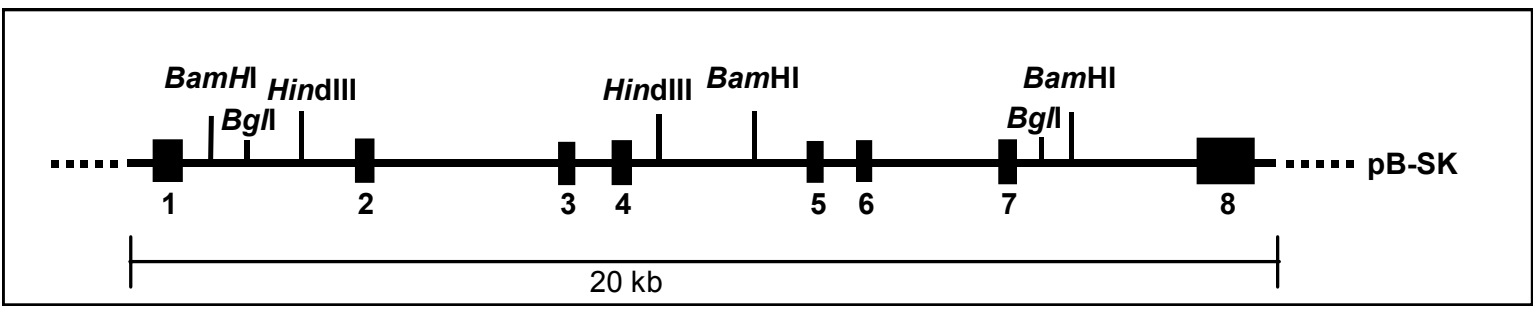

Abb. 5: Das Pmm2-Gen als subkloniertes Fragment im Vektor pBlueScript SK. Die eingezeichneten Restriktions-Schnittstellen wurden für die Konstruktion der GeneTargeting-Vektoren benutzt.

Ziel war es, zwei Gene-Targeting-Vektoren zu generieren. Ein GTV, GTV-F115L, soll auf Exon 5 die Mutation F115L enthalten, der andere, GTV-R137H, ebenfalls auf Exon 5 die R137H-Mutation. Zur Einbringung der Mutationen wurde das 4-kbBamHI-Fragment, welches die Exons 5, 6, und 7 beinhaltet, für die in-vitroMutagenesen in pBlueScript SK subkloniert. Selektionsmarker für beide Konstrukte war eine Neomycin-Kassette, die von zwei loxP-Sequenzen flankiert wurde und in das Intron 2 des HindIII-Fragmentes inseriert wurde.

\subsubsection{Integration der Neo-Kassette}

Als Selektionsmarker für beide GTV diente ein von zwei loxP-Sequenzen flankiertes Neomycin-Resistenzgen. Diese „gefloxte“ Neo-Kassette wurde in einen 
nicht kodierenden Bereich des Gens inseriert und konnte nach Selektion mit Hilfe des sequenzspezifischen Cre/loxP-Rekombinationssystems aus dem Bakteriophagen P1 (Austin et al., 1981) anschließend wieder entfernt werden. Die Cre-Rekombinase gehört einer Familie sequenzspezifischer Rekombinasen an (Argos et al., 1986). Während des Prozesses der Rekombination erkennt das CreProtein die Sequenzen der loxP-Oligonukleotide und bindet an innen. Liegen zwei dieser loxP-sites mit Cre in direktem Kontakt, bildet sich ein Komplex aus vier CreMolekülen und zwei loxP-sites. Zwischen diesen beiden Bereichen findet dann die homologe Rekombination statt.

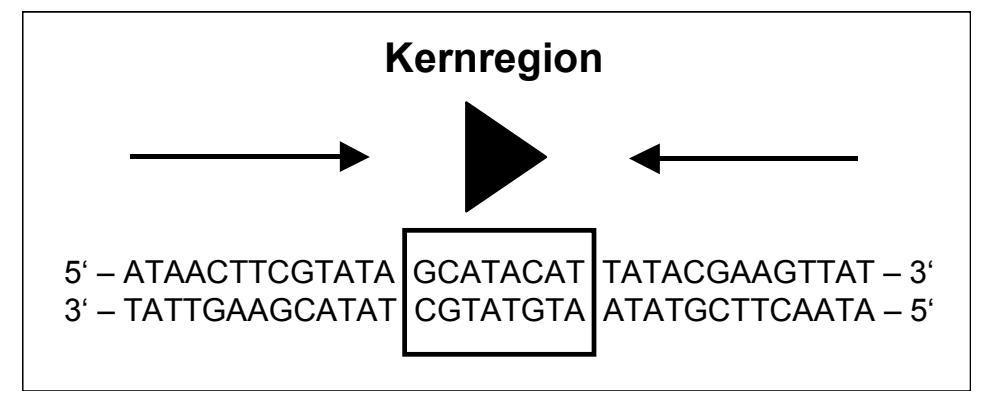

Abb. 6: $\quad$ Aufbau einer loxP-Signalsequenz. Sie besteht aus 34 Basenpaaren. Eine aus acht Basenpaaren bestehende Kernregion ist von zwei gegenläufigen identischen Sequenzen umgeben. Die nicht symmetrische Kernregion bestimmt die Orientierung der loxP-site (symbolisiert durch das Dreieck).

Liegen die loxP-Sequenzen in gleicher Orientierung, wird der dazwischenliegende DNA-Bereich herausgeschnitten; sind sie entgegengesetzt orientiert, resultiert eine Inversion des entsprechenden Bereichs (Austin et al., 1981). Befinden sich die Signalsequenzen auf unterschiedlichen DNA-Molekülen, führt dies zum intermolekularen, reziproken Austausch der die loxP-Sequenzen flankierenden Bereiche.

In der vorliegenden Arbeit wurde dieses System zur Entfernung der Neo-Kassette benutzt. Das Neomycin-Resistenzgen mit eigenem Promotor wurde von zwei loxPSignalsequenzen mit gleicher Orientierung flankiert. Somit bestand die Möglichkeit in selektierten ES-Klonen die Neo-Kassette durch Elektroporation mit der CreRekombinase wieder zu entfernen, wobei lediglich eine loxP-Signalsequenz zurückbleibt. 
Die "gefloxte" Neo-Kassette stand als 1,3 kb großes Xbal/Sall-Fragment im pBlueScript-Vektor zur Verfügung. Um es als Sall-Fragment in ein Intron des Pmm2-Gens zu inserieren, wurde durch gezielte in-vitro-Mutagenese (Primer: floxneo-Sall-rein 1, -2) vor der Xbal-site eine zweite Sall-site generiert (Abb.7).

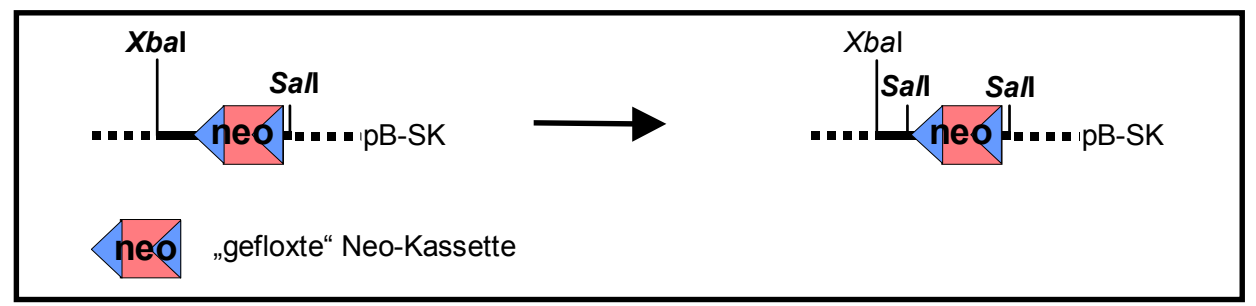

Abb. 7: Im zur Verfügung stehenden Fragment mit „gefloxter“ Neo-Kassette wurde am 5'-Ende der Neo-Kassette eine zweite Sall-site generiert.

Zur Integration der Neo-Kassette als Sall-Fragment wurde in das Intron 2, zwischen Exon 2 und Exon 3, eine Sall-site durch in-vitro-Mutagenese eingebracht. Dazu wurde das 5,5 kb große HindllI-Fragment subkloniert, welches die Exons 2, 3 und 4 einschließt. Durch in-vitro-Mutagenese (Primer: pBHindlllraus $1,-2$ ) wurde ein pBlueScript-Vektor generiert, der in seiner Multiple Cloning Site (MCS) keine Hindlll-Schnittstelle mehr besitzt. In diesen mutagenisierten Vektor (mut-pB-SK-HindIII-raus) wurde das 10-kb-BamHI-Fragment mit den Exons 2 bis 4 subkloniert. Nach einem Restriktionsverdau mit dem Enzym HindllI wurde dieses 5,5-kb-Hindlll-Fragment in einen pBlueScript-Vektor subkloniert, der in seiner MCS keine Sall-site mehr besitzt. Wie oben beschrieben wurde durch invitro-Mutagenese (Primer PMM2-Sall-rein 1, -2) eine Sall-Schnittstelle in das Intron 2 eingefügt. Nun konnte die "gefloxte" Neo-Kassette nach entsprechendem Verdau als Sall-Fragment in das Intron inseriert werden (siehe Abb.8). Dieses wurde mittels Kontrollverdau und PCR (Primer: Neo 1, TL44) überprüft. 
Das 6,8 kb große HindlII-Fragment, welches die Neo-Kassette enthielt, wurde wieder zurück in das BamHI-Fragment kloniert. Die korrekte Orientierung wurde mittels PCR bestätigt (Primer: TL42, TL61).

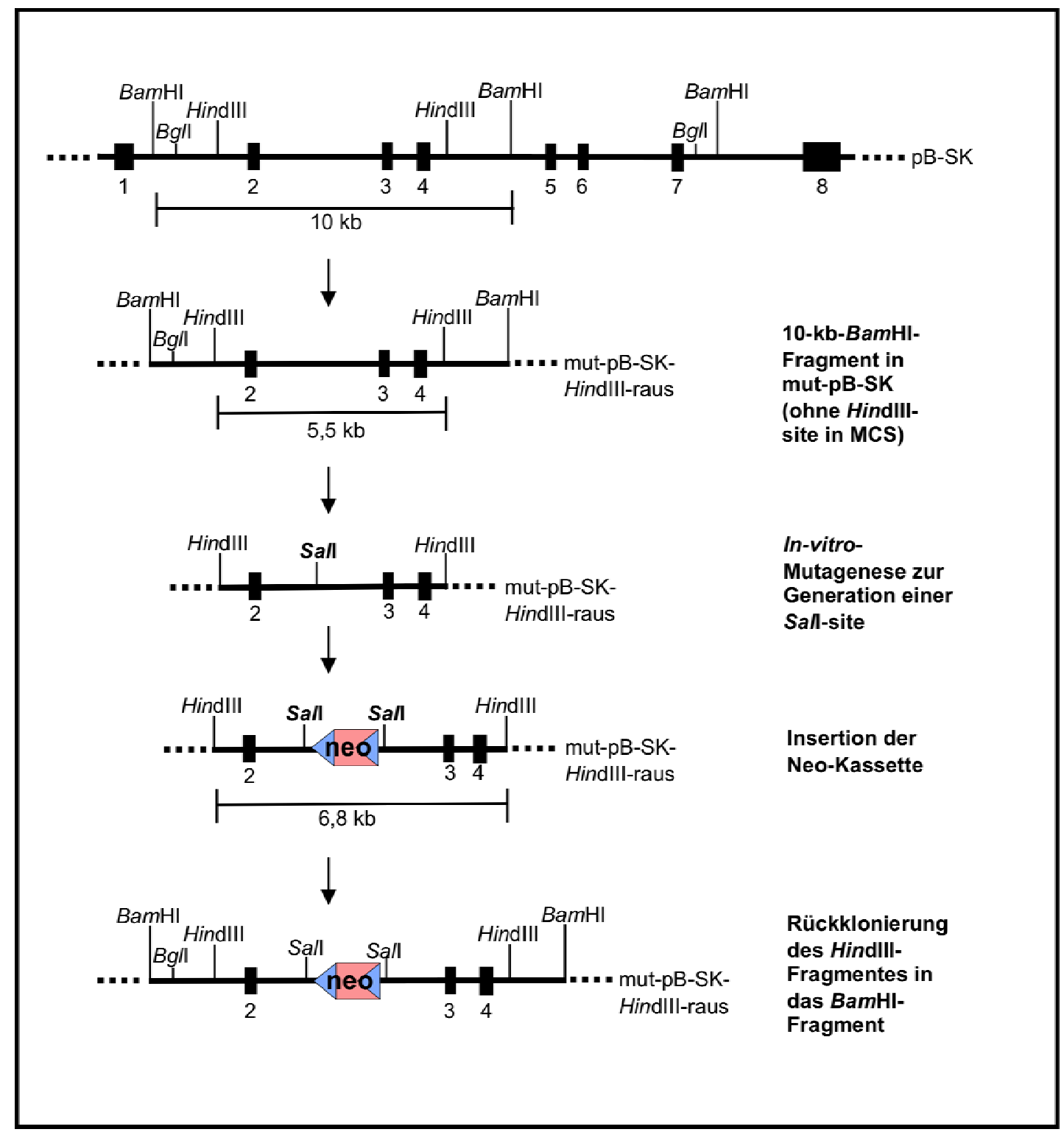

Abb. 8.: $\quad$ Schema zur Integration der Neo-Kassette. Das 10-kb-BamHI Fragment wurde in einen zuvor mutagenisierten pB-SK ohne Hindlll-site eingebracht. Nach einer weiteren Subklonierung des enthaltenen HindIII-Fragmentes und Einfügen einer Sall-site ins Intron 2 konnte die „gefloxte“ Neo-Kassette inseriert werden. 


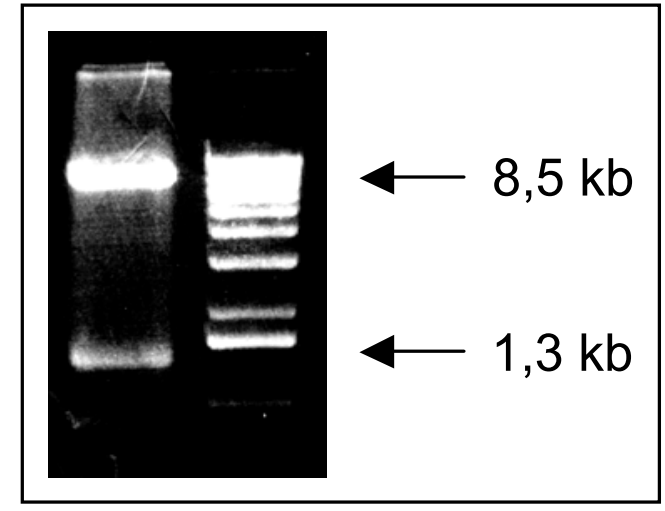

Abb: 9: $\quad$ Analytisches Agarosegel nach Sall-Kontrollverdau. Das HindIII-Fragment bildet zusammen mit dem pB-SK die Bande bei $8,5 \mathrm{~kb}$; die inserierte Neo-Kassette bildet die 1,3-kb-Bande.

\subsubsection{Einbringen der Mutation F115L bzw. R137H}

Mit Hilfe des Restriktionsenzyms BamHI wurde ein 4 kb großes Fragment subkloniert, welches die Exons 5, 6 und 7 einschließt. Sowohl die Mutation F115L als auch die R137H-Mutation wurden in Exon 5 eingebracht. Mit gezielter in-vitroMutagenese (Primer: PMM2-F119L A, -B; PMM2-R141H A, -B) wurden zwei Konstrukte hergestellt (a: 4 kb BamHI-F115L; b: 4 kb BamHI-R137H). Das codierende Triplett der Aminosäure an Position 115 für Phenylalanin wurde im Konstrukt a durch den Austausch einer Base in eine codierende Sequenz für Leucin mutagenisiert. Um im Konstrukt b die R137H-Mutation einzufügen, wurden zwei Basen ausgetauscht, so dass das veränderte Triplett an der Position 137 nun für Histidin statt Arginin codiert (Abb.: 10). 


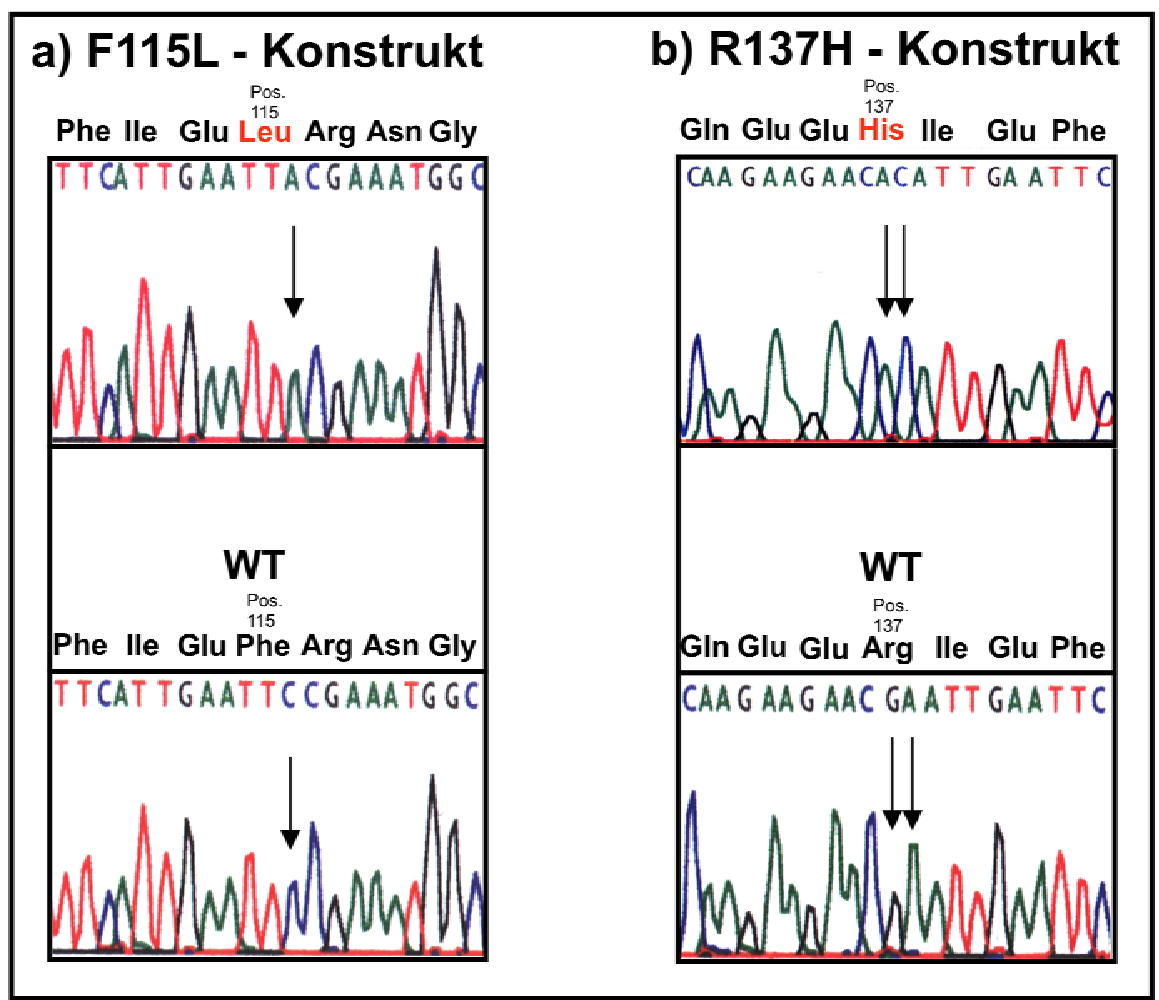

Abb. 10: Basensequenz der beiden GTV im Bereich der jeweiligen Mutation. Im Konstrukt a wurde für die F115L-Mutation mit in-vitro-Mutagenese Cytidin durch Adenin ( $\left.5^{\prime} \rightarrow 3^{\prime}\right)$ ersetzt. Statt Phenylalanin ist nun Leucin die resultierende Aminosäure. Im Konstrukt b wurden Guanin und Adenin gegen Adenin und Cytidin $\left(5^{\prime} \rightarrow 3^{\prime}\right)$ ausgetauscht, so dass die Basen für Histidin und nicht für Arginin codieren. Die mit WT bezeichneten Sequenzen zeigen die ursprünglichen Wildtyp-Sequenzen im entsprechenden Bereich.

\subsubsection{Zusammenfügen der Fragmente für GTV-F115L und GTV- R137H}

Die vorbereiteten Fragmente für die beiden GTV mussten anschließend in ursprünglicher Orientierung wieder zusammengefügt werden. Es handelte sich um ein 11,3-kb-BamHI-Fragment, welches die "gefloxte" Neo-Kassette enthält, je ein 4-kb-BamHI-Fragment mit der Mutation F115L bzw. R137H (Konstrukt a und b) und den entsprechenden Vektor, ebenfalls mit BamHI-Enden. Eine Drei-FragmentLigation schlug fehl, darum wurden in den zwei subklonierten 4-kb-BamHIFragmenten, welche die beiden Mutationen enthielten, die 3'-gelegene BamHI-site 
mittels in-vitro-Mutagenese beseitigt (Primer: 4kb BamHI raus 1, -2). Nach BamHIVerdau ergab sich nachfolgend ein linearisiertes 7-kb-Konstrukt, bestehend aus dem jeweiligen 4-kb-BamHI-Fragment und dem 3-kb-pBlueScript-Vektor (Abb. 11b).

Nach der Entfernung der 3'-BamHI-Schnittstelle konnten das 11,3-kb-BamHIFragment und das 7-kb-BamHI-Fragment ligiert werden (Abb. 11a). Die erfolgte Ligation und die richtige Orientierung dieser beiden Fragmente zueinander wurden mittels entsprechenden Kontrollverdaus und PCR überprüft (Primer: TL27, PMM2F119L-B, Abb. 11c).

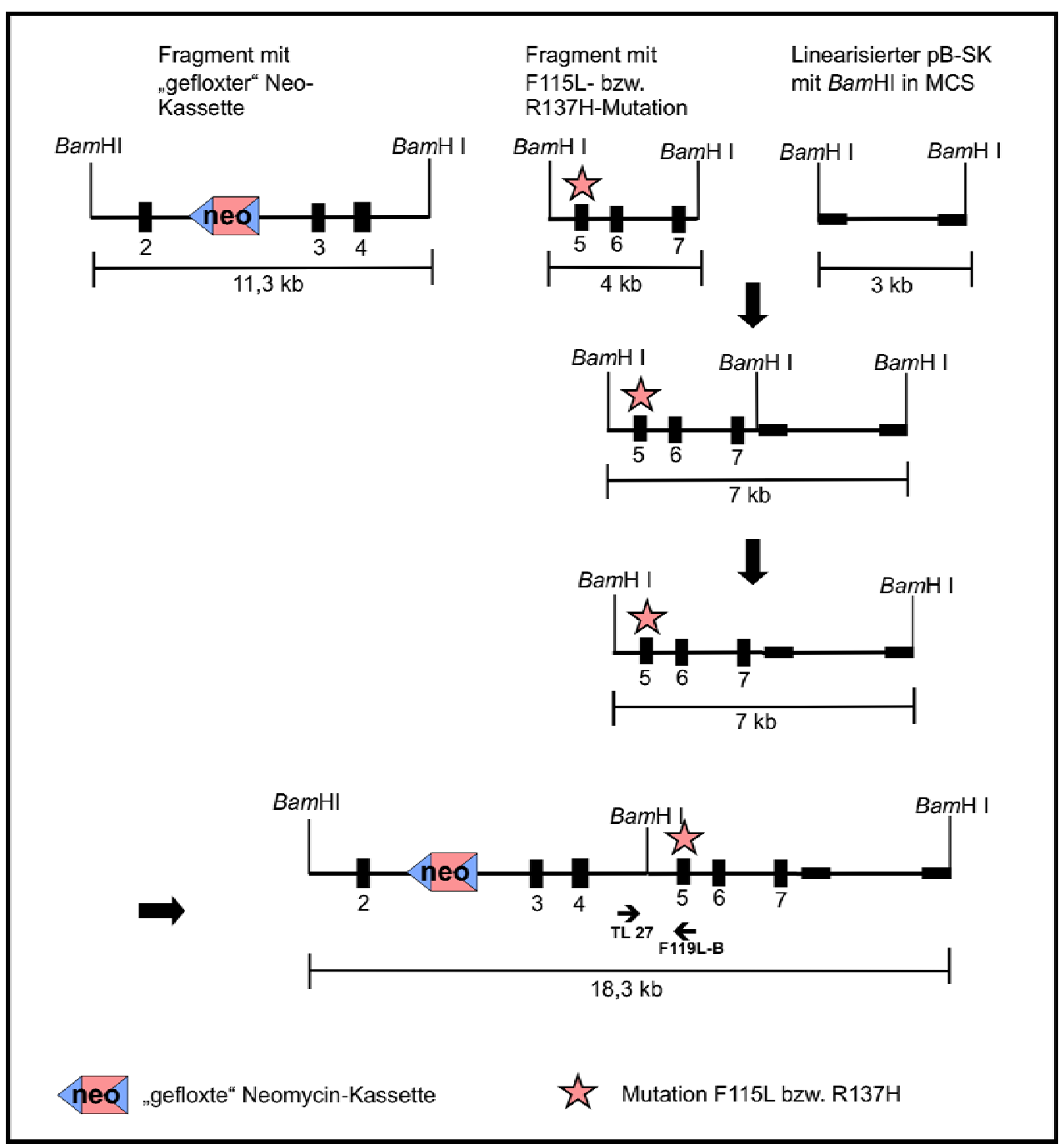

Abb. 11a: Schema zur 3-Fragment-Ligation. Zwei BamHI-Fragmente mit je 4 und $3 \mathrm{~kb}$ wurden ligiert, um anschließend die mittig gelegene BamHI-site zu entfernen. Nach Kontrolle der richtigen Orientierung wurde das dritte BamHI-Fragment mit Neo-Kassette ligiert. 


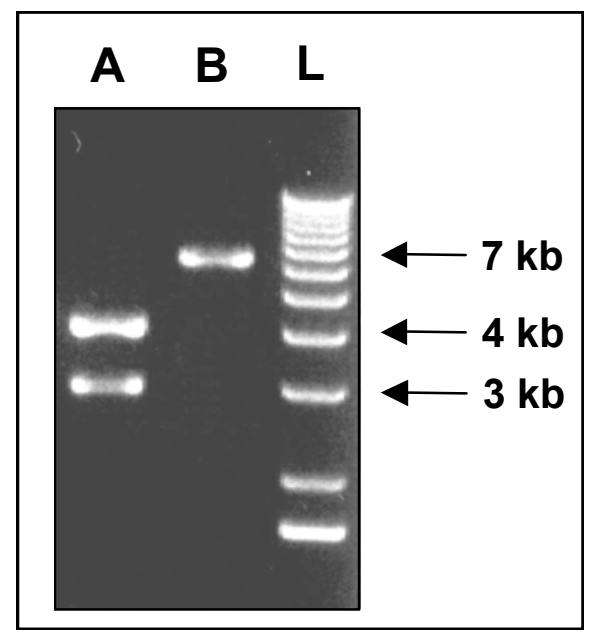

Abb. 11b: $\quad$ Analytisches Agarosegel nach Kontrollverdau mit BamHI. Spur A zeigt den Vektor bei $3 \mathrm{~kb}$ und das 4-kb-BamHI-Fragment vor der Mutagenese zur Zerstörung der 3' BamHI-site. In Spur B erkennt man die erfolgreiche Mutagenese. Das BamHI-Fragment und der Vektor liegen linearisiert bei $7 \mathrm{~kb}$ vor. Diese Mutagenese wurde für Konstrukt $a$ und $b$ durchgeführt.

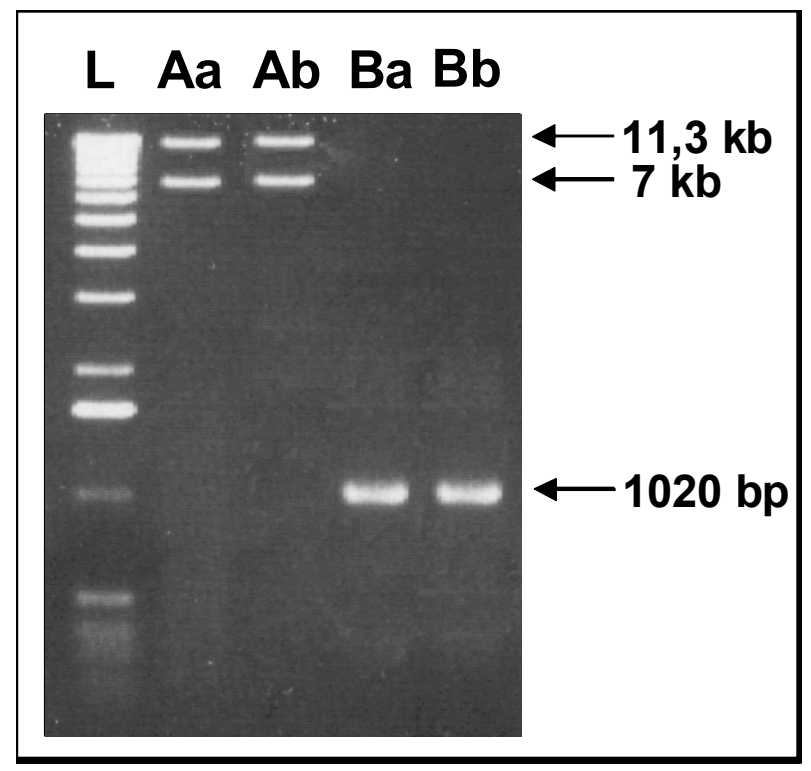

Abb. 11c: Analytisches Agarosegel zur 3-Fragment-Ligation. Aa,Ab: Kontrollverdau der Fragmente nach Entfernung der 3'-BamHI-site für Konstrukt a und b mit BamHI. $\mathrm{Ba}, \mathrm{Bb}$ : Bande nach PCR mit Primern TL27 und F119L-B. Durch korrekte Orientierung der Fragmente entsteht für beide Konstrukte jeweils eine Bande bei $1020 \mathrm{bp}$. 


\subsubsection{Vorbereitung der zwei GTV zur Elektroporation}

Für eine höchstmögliche Effizienz der Elektroporation mit anschließender homologer Rekombination sollte das verwendete Targeting-Konstrukt mehr als 10 $\mathrm{kb}$ homologe DNA-Sequenz besitzen, wovon mindestens 1,5 kb sowohl am 5'- als auch am 3'-Ende liegen sollten. Zudem sollte das Konstrukt in linearisierter Form elektroporiert werden. Aus diesen Gründen wurde ein Restriktionsverdau mit Bg/l durchgeführt, das am 5'-Ende vor dem Exon 2 und hinter Exon 6 am 3'-Ende schneidet, um ein 14,3 kb großes Fragment zu generieren (Abb. 12).

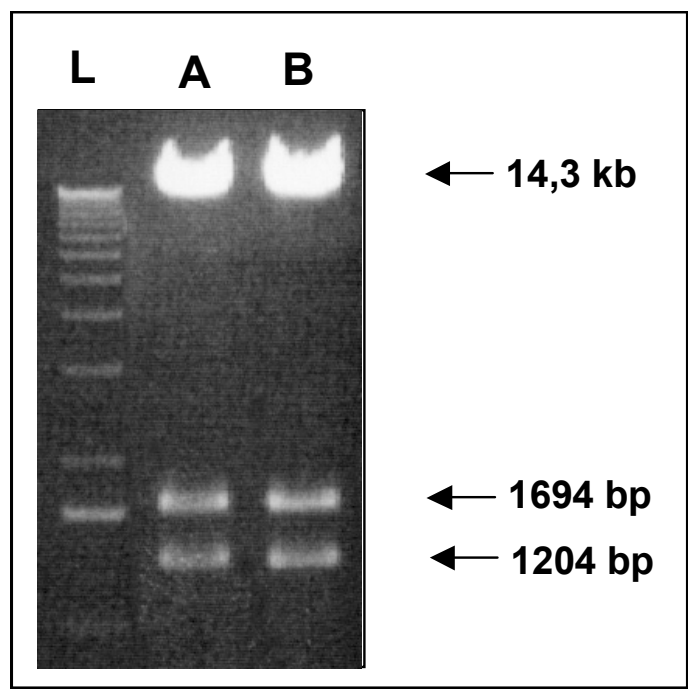

Abb. 12: $\quad$ Gelelektrophorese nach Bgll-Verdau des F115L-Konstruktes (A) und des R137H-Konstruktes (B). Das 14,3-kb-Bgll-Fragment wurde jeweils gelextrahiert und zur Elektroporation verwendet. Die beiden kleineren Banden bei 1694 bp und 1204 bp entstanden durch eine weitere Bg/l-site in der MCS des Vektors.

Nach gelelektrophoretischer Auftrennung und Extraktion entstand ein BgllFragment mit "gefloxter" Neo-Kassette und F115L-Mutation, sowie eines mit der R137H-Mutation. Das jeweilige linearisierte Bgll-Fragment kann nach erfolgter Gel-Extraktion zur Elektroporation genutzt werden. 


\subsection{Homologe Rekombination in ES-Zellen}

\subsubsection{Elektroporation der ES-Zellen}

Embryonale Stammzellen wurden auf Feederzellen kultiviert und bei Erreichen einer ausreichenden Zelldichte durch Elektroporation mit den linearisierten Bg/lFragmenten transfiziert. Die anschließende Selektion der rekombinanten Klone wurde mit $\mathrm{G} 418^{\circledR}$ durchgeführt. In jeweils sieben Elektroporationsrunden wurden von beiden Zellreihen (GTV-F115L und GTV-R137H) 840 bzw. 900 überlebende Klone isoliert und getrennt kultiviert. Ein Teil der Zellen jedes Klones wurde eingefroren und aus dem Rest wurde genomische DNA zur Analyse präpariert.

\subsubsection{Southern-Blot-Analyse der selektierten Klone}

Ein Teil der präparierten DNA aus jedem der insgesamt 1740 Klone wurde mit dem Restriktionsenzym BamHI verdaut, gelelektrophoretisch aufgetrennt und mit Hilfe eines Southern-Blots auf homologe Rekombinations-Ereignisse untersucht. Es wurde eine externe Sonde (Primer: TL24, TL25) verwendet, die 5' des zweiten Exons und innerhalb des BamHI-Fragmentes bindet. Das Wildtyp-Fragment hat eine Länge von $10 \mathrm{~kb}$, während das Fragment des rekombinanten Allels durch die Insertion der Neo-Kassette eine Länge von 11,3 kb aufwies (Abb. 13a und 13b). 


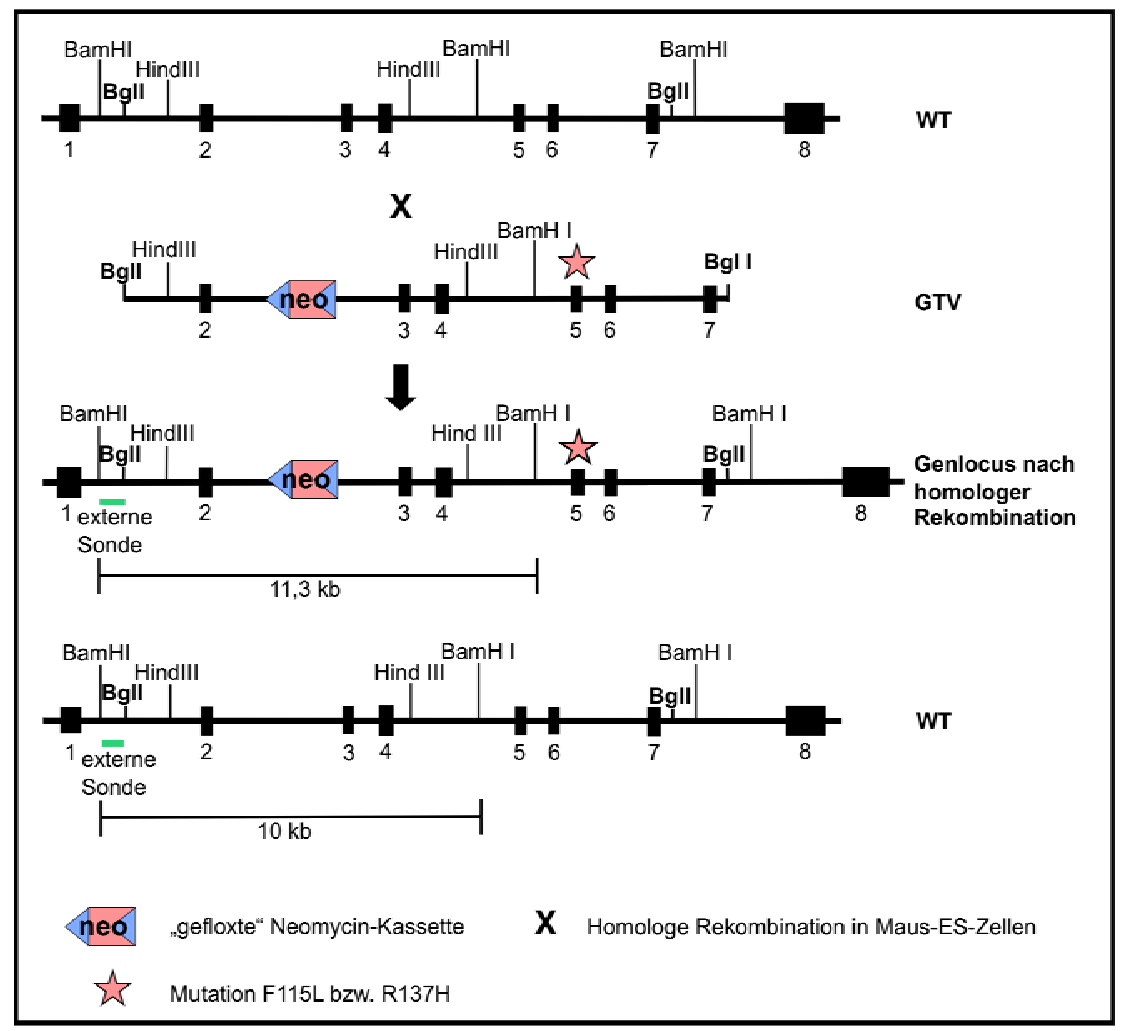

Abb. 13a: Schematische Darstellung der homologen Rekombination.

Abb 13b:

Bandenmuster nach Southern-Blot mit genomischer DNA aus verschiedenen ES-Zell-Klonen und einer Kontroll-DNA. Sowohl die Kontrolle (Ko.) als auch die exemplarisch ausgewählten Klone F93 und R48 zeigen eine Bande bei $10 \mathrm{~kb}$. Die Klone F92, F94, R50 und R54 weisen eine zusätzliche Bande bei 11,3 kb auf.

Die Klone F92, F94, R50 und R54 aus der siebten Elektroporationsrunde (die Bezeichnung der Klone mit ,F' und ,R' richten sich nach dem elektroporierten Konstrukt; GTV-,F'115L, GTV-,R'137H) wiesen gegenüber der nicht transfizierten 
Kontrolle im Southern-Blot eine zusätzliche Bande bei 11,3 kb auf. Diese Veränderung des Bandenmusters konnte bei 0,24 \% der selektionierten F115LKlone und 0,22 \% der selektionierten R137H-Klone nachgewiesen werden. ESZell-Klone mit rekombinantem Allel wurden zusätzlich auf die eingebrachten Mutationen F115L und R137H hin untersucht. Mittels einer nested-PCR mit zwei externen Primern (PMM2-Test A, 4kb rev 1; PMM2-Test D, 4kb rev 2) wurde ein 3500-bp-Fragment amplifiziert (Abb. 14a), welches die Exons 5, 6 und 7 enthielt.

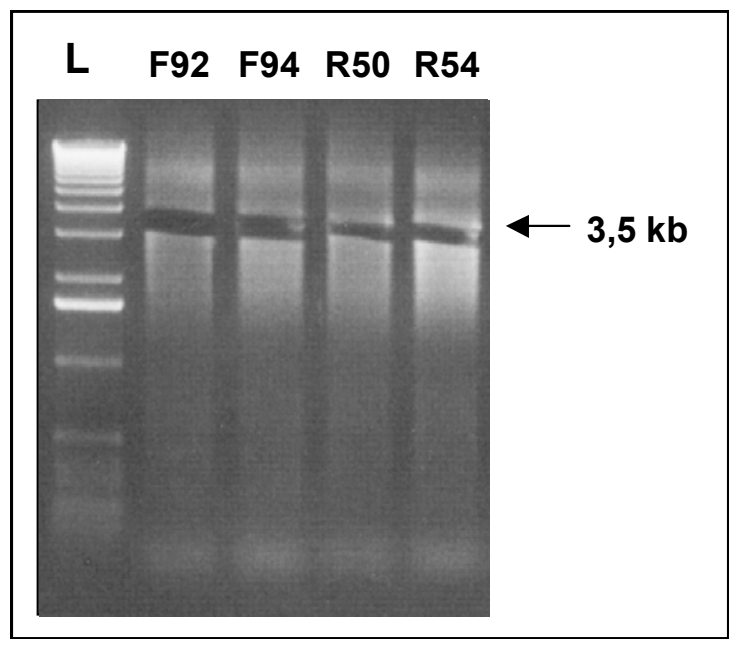

Abb. 14a: Gelelektrophorese-Foto nach Gelextraktion der Banden bei 3,5 kb zur Sequenzierung. Die jeweilige Bande ergab sich nach einer nested-PCR mit Primern PMM2-Test A, 4kb rev 1, PMM2-Test D, 4kb rev 2. Ausgangsmaterial war genomische DNA der Klone F92, F94, R50 und R54.

Sowohl die Klone, die mit dem F115L-Konstrukt transfiziert worden sind, als auch die R137H-transfizierten Klone wiesen Heterozygotie für die entsprechende Mutation auf (Abb. 14b). 


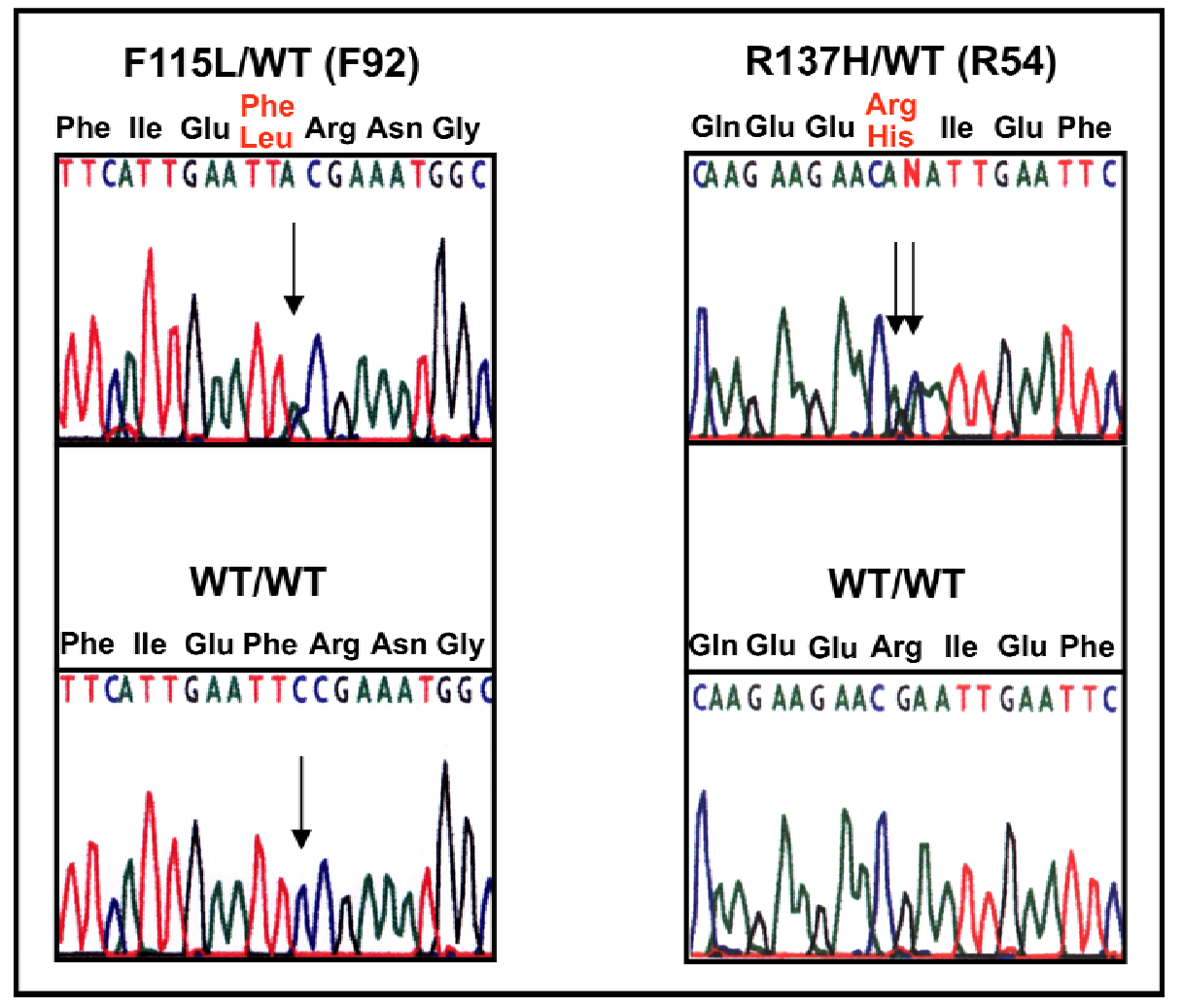

Abb.14b: Vergleich genomischer DNA-Sequenzen von F92, R54 und Wildtyp im Bereich der eingeführten Mutationen.

Zwei dieser positiv getesteten Klone, F92 mit dem Genotyp F115L+Neo/WT und R54 mit Genotyp R137H+Neo/WT, wurden für die Cre-Rekombinase-Reaktion zum Ausschneiden der Neo-Kassette vorbereitet. Dazu wurden beide Klone aus den eingefrorenen Beständen aufgetaut und kultiviert, bis sie eine geeignete Dichte auf den Feeder-Platten besaßen. Diese ES-Zellen wurden dann mit $30 \mu \mathrm{g}$ eines Cre-Rekombinase-Gen enthaltenen Plasmides elektroporiert. Die transgenen ES-Zellen konnten nach dieser Elektroporation nicht selektiert werden, da der Selektionsmarker bei erfolgreicher Cre-Rekombinase-Reaktion entfernt wurde. Aus beiden Zelllinien wurden je 120 Klone isoliert und kultiviert. Ein Teil jedes Klones wurde eingefroren, der andere Teil für die Präparation der DNA benutzt. Die Überprüfung der Klone erfolgte erneut durch BamHI-Verdau der DNA und anschließenden Southern-Blot mit der bereits beschriebenen externen Sonde (Abb. 15). 


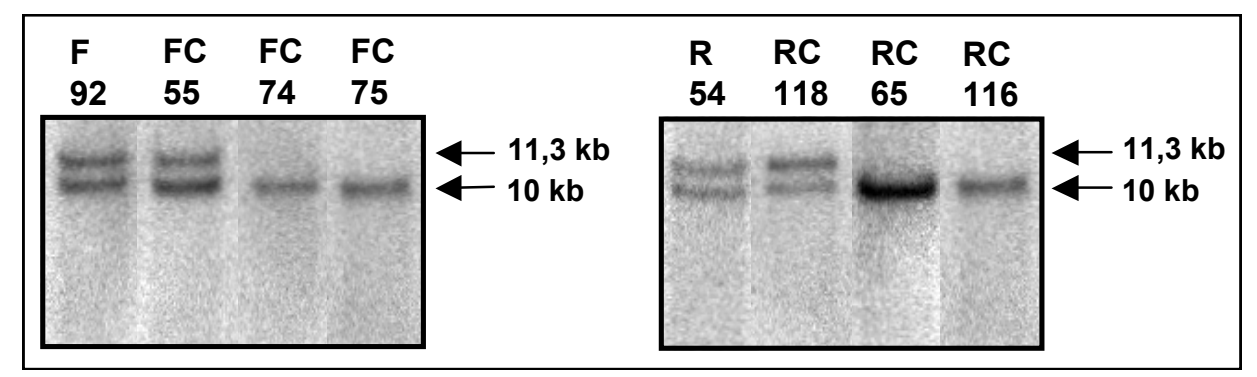

Abb. 15:

Bandenmuster nach Southern-Blot mit genomischer DNA der Ausgangsklone F92 bzw. R54 und deren jeweilige ES-Zell-Klone nach der Cre-Rekombinase-Reaktion.

Bei den Klonen FC74 und FC75 sind die Banden des rekombinanten Allels bei $11,3 \mathrm{~kb}$, wie sie im Ausgangsklon F92 noch zu sehen war, nicht mehr vorhanden. Gleiches war auch bei den Klonen RC65 und RC116 zu beobachten, die beide dem Ausgangsklon R54 entstammten. Eine erfolgreiche Cre-RekombinaseReaktion mit entsprechendem Ausschneiden der Neo-Kassette konnte bei jeweils vier von 60 Klonen beobachtet werden. Die im Intron verbliebenen 34 Basenpaare der loxP-site im rekombinanten Allel sind in der gelelektrophoretischen Auftrennung nicht zu erkennen. Die eingebrachten Mutationen F115L bzw. R137H wurden in oben beschriebener Weise erneut bestätigt. 


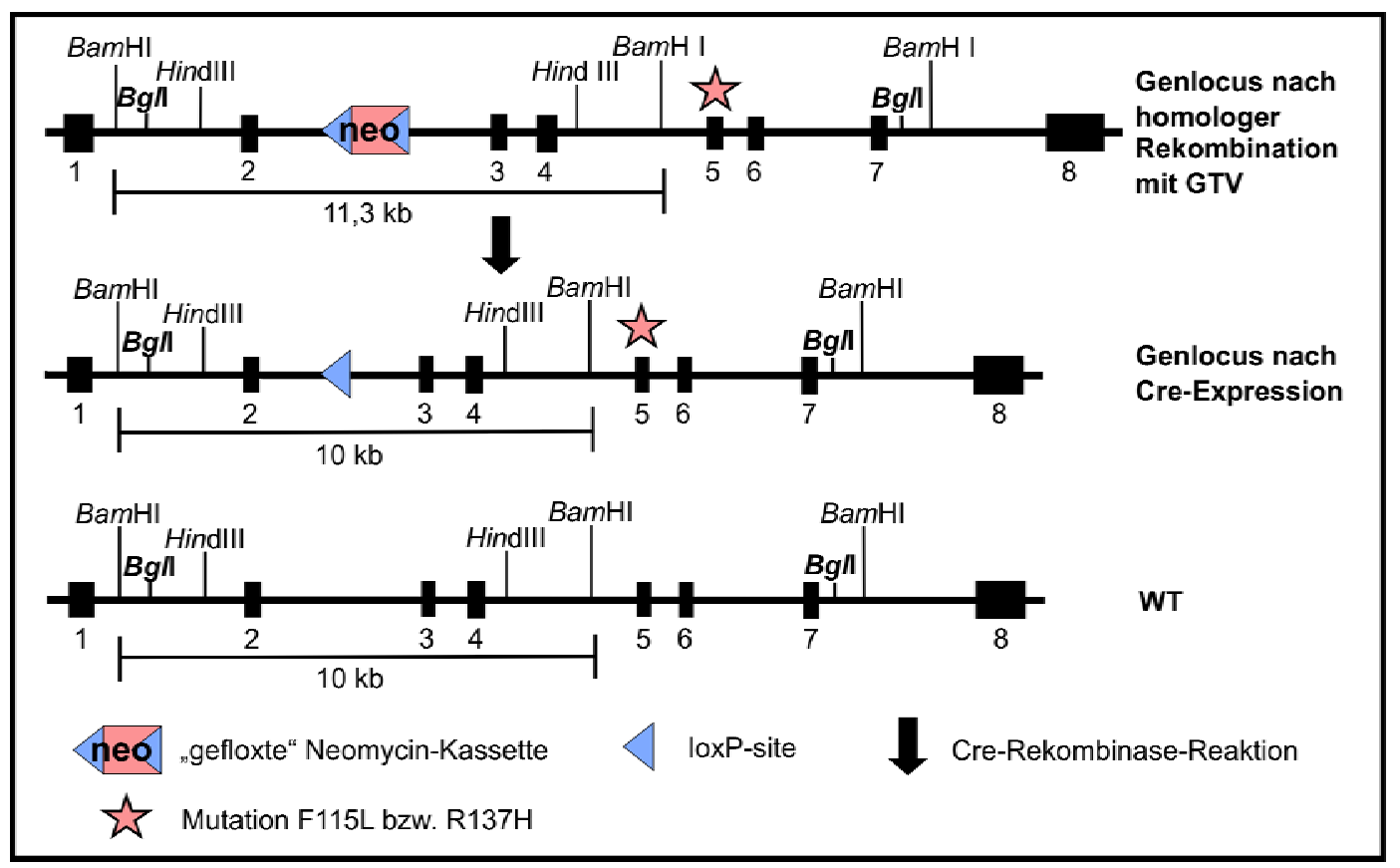

Abb. 16:

Schematische Darstellung des Pmm2-Genlocus zur Cre-RekombinaseReaktion

\subsection{Mikroinjektion der ES-Zellen}

Insgesamt stehen jeweils 4 rekombinante Klone je Mutation (R137H und F115L) zur Erzeugung der Keimbahnchimären zur Verfügung. 


\section{Diskussion}

\subsection{CDG-la}

Bei CDG-la-Patienten ist die Synthese der Glykoproteine an einem sehr frühen Zeitpunkt gestört. Der Defekt wird durch die stark verminderte Aktivität des zytosolischen Enzyms Phosphomannomutase 2 ausgelöst. Es setzt Mannose-6Phosphat in Mannose-1-Phosphat um (van Schaftingen und Jaeken, 1995). Als Konsequenz sinkt nachfolgend die Konzentration von GDP-Mannose und Dol-PMannose. Da GDP-Man und Dol-P-Man für die Synthese der lipidverknüpften Oligosaccharide (LLO) benötigt werden, entstehen in den nachfolgenden Schritten meist unvollständige LLOs wie Man ${ }_{5} \mathrm{Glc}_{\mathrm{NAc}}$ (Panneerselvam und Freeze, 1996). Die verkürzten LLOs werden nur mit sehr geringer Effizienz vom OST auf ein Protein übertragen (Körner et al., 1998); so dass es zum partiellen Verlust ganzer Oligosaccharid-Seitenketten auf dem reifen Glykoprotein kommt.

Da Glykoproteine im Organismus vielfältige und wichtige Funktionen ausüben, ist auch das phänotypische Spektrum der CDG-la-Patienten weitreichend und heterogen. Man kann die Patienten nach ihrem klinischen Bild grob in zwei Gruppen einteilen. Eine Gruppe fällt vorrangig durch neurologische Defizite auf, während die zweite Gruppe über die neurologischen Probleme hinaus auch schwerwiegende intestinale Komplikationen entwickelt. Des Weiteren variieren die Ausprägungen der Symptome unter den CDG-la-Patienten stark. Das Spektrum reicht von Kindern, die mit axialer Hypotonie der Muskulatur und psychomotorischen Retardierungen verhältnismäßig leicht betroffen sind, bis hin zu Kindern mit zusätzlichem Strabismus, Areflexie, Epilepsie und cerebellärer Hypoplasie. Auch bei den extraneurologischen Symptomen reicht es von leichten Wachstums-Retardierungen bis zu ständigem Erbrechen, Diarrhoe, Steatorrhoe und Anorexie (de Lonlay et al., 2001, Jaeken und Carchon 2004). In beiden Gruppen können häufig dysmorphe Zeichen wie invertierte Brustwarzen oder ungewöhnliche Fettansammlungen im Oberarm- und Gesäßbereich beobachtet werden. 


\subsection{Therapieansätze}

Bisher existiert keine wirksame Therapie für CDG-la-Patienten. Die Behandlung erfolgt lediglich symptomatisch. Jedoch sind mit dem Wissen über die biochemischen Grundlagen der Erkankung einige Therapieansätze veröffentlicht worden.

So wurden Haut-Fibroblasten von CDG-la-Patienten in der Zellkultur auf die Zucker-Struktur ihrer lipid-verknüpften Oligosaccharide (LLO) untersucht. Im Gegensatz zu gesunden Kontroll-Fibroblasten konnten in den Zellen der Patienten zum großen Teil nur unvollständig glykosylierte Vorstufen der LLOs nachgewiesen werden. Dieser Defekt konnte durch Zuführung eines mannosereichen Nährmediums ausgeglichen werden. Analysen der Oligosaccharide von CDG-laFibroblasten und Kontroll-Fibroblasten zeigten nach der Behandlung mit Mannose keine Unterschiede mehr (Körner et al., 1998; Panneerselvam and Freeze, 1996). Zudem steigt die GDP-Mannose-Konzentration in den Patienten-Fibroblasten von durchschnittlich $2,4 \mathrm{pmol} / 10^{6}$ Zellen auf $15,5 \mathrm{pmol} / 10^{6}$ Zellen, was ca. $75 \%$ der GDP-Mannose in gesunden Fibroblasten-Zellen entspicht (Rush et al., 2000). Scheinbar kann durch die exogene Zufuhr des Substrates Mannose die verminderte Aktivität der Phosphomannomutase annähernd kompensiert werden.

Versuche, diesen Therapieansatz auch auf CDG-la-Patienten zu übertragen, zeigten bislang keine Erfolge. Durch die Gabe von Mannose (sowohl oral als auch intravenös) konnte die Mannose-Konzentration im Serum der Patienten auf ein mehrfaches des Normalen angehoben werden. Es zeigte sich jedoch weder eine Verbesserung des gesundheitlichen Zustandes der behandelten Kinder noch eine

Verbesserung der unvollständig synthetisierten Glykoproteine (Mayatepek et al., 1997; Mayatepek und Kohlmüller, 1998). Die Ursache für die unterschiedlichen Effekte in der Fibroblastenkultur und beim CDG-la-Patienten ist bislang nicht geklärt.

Ein anderes Therapiekonzept ist es, den Defekt der PMM2 zu umgehen und den Zellen Mannose-1-Phosphat zuzuführen. Mannose-1-Phosphat selbst ist jedoch wegen der hohen Polarität nicht membrangängig und kann nicht in die Zellen transportiert werden. Darum arbeiten mehrere Arbeitsgruppen daran, membrangängige Derivate zu synthetisieren. Nach Applikation und Aufnahme dieser Prodrugs in die Zelle, steht nach intrazellulärer und enzymatischer 
Wiederaufarbeitung Mannose-1-Phosphat der N-Glykosylierung zur Verfügung. Bisher veröffentlichten Prodrugs mangelt es derzeit noch an Stabilität der Verbindung und damit einer ausreichenden Halbwertszeit. Zudem sind relativ hohe Konzentrationen im Serum nötig, um suffizient über die Zellmembran aufgenommen zu werden. In diesem Zusammenhang muss auch die Toxität der bisher verfügbaren Derivate genannt werden, die in den notwendigen Konzentrationen auftritt. Einige Prodrugs konnten in der Zellkultur von CDG-laFibroblasten die gestörte LLO-Synthese normalisieren (Muus et al., 2004; Eklund et al., 2005, Hardré et al., 2007).

Um diese und andere Therapie-Optionen an höher entwickelten Organismen zu testen und um mehr über die Pathophysiologie zu lernen, wurde versucht, ein Mausmodell für CDG-la zu entwickeln (Thiel et al., 2006).

\subsection{Pmm2-Knock-Out}

Thiel et al. schalteten das Pmm2-Gen in Mäusen gezielt aus. Heterozygote Tiere für diesen Pmm2-Knock-Out zeigten sich in Entwicklung, Fertilität und Anatomie unverändert zu den Wildtyp-Tieren. Hingegen konnten keine homozygoten Mäuse mit einem Pmm2-Knock-Out unter den 220 Nachkommen von verpaarten heterozygoten Tieren gefunden werden. Erst genotypische Untersuchungen in der frühen embryonalen Entwicklung dieser Nachkommen konnten bis zum Tag 2,5 nach Befruchtung homozygote Embryonen mit einem Pmm2-Null-Allel nachweisen (Thiel et al., 2006). Dies lässt vermuten, dass ein vollständiger Knock-Out des Pmm2-Gens nicht mit dem Leben vereinbar ist und zu einer sehr frühen embryonalen Entwicklungsstörung führt. Korrespondierend beginnt um den Tag 2,5 des Embryos die Poteinbiosynthese und der Abbau der maternalen RNA ist zu $90 \%$ erfolgt (Schultz, 2002).

Eine weitere Erklärung für ein embryonales Absterben zu diesem Zeitpunkt könnten Hindernisse in der Nidation der befruchteten Eizelle im Uterus sein. Kitamura et al. meinen, dass Glykoproteine an der Zelloberfläche in den interzellulären Erkennungsmechanismen zwischen Embryo und dem Epithel des Endometriums eine wichtige Rolle spielen (Kitamura et al., 2003). Durch die gestörte Glykoproteinbiosynthese in den Pmm2-defizienten Zellen ist es 
wahrscheinlich, dass auch diese Oberflächenproteine ungenügend ausgebildet sind und die Nidation behindern wird.

Weiterführende Verpaarungen von männlichen und weiblichen heterozygoten Mäusen mit Wildtyp-Mäusen zeigten eine stark verminderte Weitergabe des weiblichen Null-Allels. So wurde das männliche Null-Allel zu $48 \%$ an die Nachkommen weitergegeben, hingegen das weibliche nur zu $20 \%$. Statt einer erwarteten Heterozygoten-Quote von 1:1 zeigte sich ein Verhältnis von 4:1 für die Wildtyp-Nachkommen (Thiel et al., 2006). Es scheint demnach die Befruchtung selbst oder die Oogenese durch das Pmm2-Null-Allel gestört zu sein.

Um die frühe Letalität des „Pmm2 Knock-Out“ zu umgehen, begannen wir mit der Entwicklung eines hypomorphen Mausmodells mit einer Restaktivität der Phosphomannomutase, wie sie auch Patienten mit dem CDG-la-Syndrom zeigen. Die vorliegende Arbeit beschreibt die Erstellung zweier Gene-Targeting-Vektoren für die zwei häufigsten Mutationen im PMM2-Gen von compound-heterozygoten Patienten, R141H und F119L. Diese Mutationen entsprechen der R137H- und F115L-Mutation im Pmm2-Gen der Maus.

\subsection{Mutation R141H und F119L}

Die beiden häufigsten Mutationen im PMM2-Gen sind R141H und F119L. Einen spezifischen Phänotyp für diese compound-Heterozygotie findet man nicht (Erlandson et al., 2001). Jedoch scheint der Genotyp R141H/F119L eher den klinisch schwerer betroffenen Anteil der CDG-la-Patienten zu repräsentieren. In einer Studie von Kjaergaard et al. aus 2001 wurden 25 Patienten mit diesem häufigen Genotyp untersucht. Sie zeigten einheitlich und früh Probleme in der Ernährung, schwere Wachstumsverzögerungen, stark ausgeprägte axiale muskuläre Hypotonie, invertierte Brustwarzen und subkutane Fettansammlungen. Hinzu kamen hepatische Dysfunktionen, Perikardergüsse und Entwicklungsverzögerungen.

In einer weiteren Studie von Kjaergaard et al. aus dem Jahr 2002 lässt sich erkennen, dass im Entwicklungsverlauf der am R141H/F119L-Genotyp erkrankten Kinder diese zwar ein normales fetales Wachstum zeigen, sich jedoch im sofortigen Anschluss an die Geburt ein Defizit einstellt. Körpergewicht, 
Körperlänge, Body-Mass-Index (BMI) und Kopfumfang wuchsen in den ersten sechs Monaten nicht so schnell wie die Maße einer Vergleichsgruppe. So zeigte das Geburtsgewicht gemessen als Standard deviation score (SDS) bei Geburt 0.3; dieser sank in den nächsten sechs Monaten bis auf -3 SDS ab und blieb auch erniedrigt bzw. stieg nur leicht an. Der SDS-Kopfumfang fiel von gemessenen $0 \mathrm{im}$ Alter von drei Monaten auf -1.9 mit fünf Jahren. Diese Daten zeigen aber auch, dass sich die Krankheit mit zunehmendem Alter zu stabilisieren scheint. Untersuchungen über das Lebensalter von CDG-la-Patienten unterstützen diese Tendenz (Matthijs et al., 2000).

Mit Mausmodellen, jeweils heterozygot für die hypomorphen Mutationen R137H und F115L, wäre die Möglichkeit gegeben, die CDG-la-Erkrankung des Menschen nachzuahmen. Beide Mausmodelle müssten mit der heterozygoten Mutation unbeeinträchtigt lebensfähig sein, da selbst der vollständige Knock-Out keinerlei Auffälligkeiten im Vergleich mit Wildtyp-Mäusen zeigt, wenn nur ein Allel betroffen ist (Thiel et al., 2006).

Anschließende Verpaarungen zweier Tiere mit jeweils einer unterschiedlichen Mutation ergäben ein Mausmodell compound heterozygot für R137H und F115L und würden so, wie oben bereits beschrieben, den am häufigsten vorkommenden Genotyp der CDG-la-Patienten repräsentieren.

Mit der Verpaarung zweier heterozygoter F115L-Tiere ließe sich ein milder Phänotyp errreichen. Der entsprechende Genotyp müsste dann nach dem HardyWeinberg-Gleichgewicht zu $25 \%$ unter den Nachkommen zu finden sein. Genotypisierungen von CDG-la-Patienten bestätigen dieses Gleichgewicht (Matthijs et al., 1998). Demnach scheint die Weitergabe des hypomorphen Allels mit dieser Mutation nicht stark eingeschränkt zu sein; anders als der vollständige Knock-Out von Pmm2 (Thiel et al., 2006).

Verpaarungen von heterozygoten Mäusen für die R137H-Mutation würden mutmaßlich keine lebenden Nachkommen ergeben, die eine Homozygotie für diese Mutation aufweisen. Dafür spricht sowohl, dass entgegen der HardyWeinberg-Formel kein Patient mit entsprechendem Genotyp diagnostiziert worden ist, als auch die fehlende Restaktivität des rekombinanten PMM2-Proteins mit der R141H-Mutation (Kjaergaard et al., 1998, Pirard et al., 1999). Genotypische Untersuchungen der Embryonen könnten zeigen, ob und in welchem Stadium die 
Mutation letal wäre und ob es Unterschiede zu den oben genannten Untersuchungen bei Pmm2-Knock-Out-Mäusen gibt.

\subsection{Effizienz der Transfektionen}

Das Ereignis der homologen Rekombination in embryonalen Stammzellen ist ein seltenes Ereignis unter den DNA-Integrationsmechanismen. Tausend mal häufiger ist der zufällige und nicht-homolog rekombinante Einbau einer Fremd-DNA (Sargent und Wilson, 1998). Zudem erfolgt die Aufnahme eines TargetingKonstruktes im Rahmen einer Elektroporation nur in einer von 2400 Zellen (Vasquez et al., 2001). Unter Verwendung von Selektionsmarkern, wie in dem vorliegenden Fall mit einer Neomycin-Kassette, und anschließender SouthernBlot-Analyse können dennoch Klone mit erfolgter homologer Rekombination selektiert werden.

In dieser Arbeit wurden insgesamt 1740 Klone nach Elektroporation mit den beiden Gene-Targeting-Vektoren (GTV-F115L und GTV-R137H) und der G418Selektion untersucht. Die homologe Rekombination konnte bei ca. 0,2 \% der Klone nachgewiesen werden, unabhängig vom verwendeten GTV. Der Anteil an erfolgreicher homologer Rekombination liegt somit unterhalb der in der Literatur beschriebenen Effizienzrate von 1 bis 15 \% (Mamo et al., 2010; te Riele et al., 1992), was möglicherweise auf eine der Anlagerung des GTVs hinderliche Konformation des Pmm2-Locus zurückgeführt werden kann.

Die anschließende Elektroporation eines Cre-Plasmids in ES-Zellen, die positiv auf die homologe Rekombination hin überprüft worden sind, zur Deletion der Neomycin-Kassette aus dem Pmm2-Locus, konnte bei jeweils 4 von 60 Klonen mit GTV-F115L und GTV-R137H erfolgreich nachgewiesen werden. Dies entspricht einer Ereignisrate von ca. 7 \%, was einer in der Literatur beschriebenen Effizienz der erfolgreichen Cre-Rekombinase-Reaktion entspricht (Meinzinger 2004).

\subsection{Isoenzym PMM1}

Neben dem zuvor beschriebenem Enzym PMM2 wurde 1997 auch das Isoenzym PMM1 entdeckt (Matthijs et al., 1997a,b). Das Gen PMM1 liegt auf Chromosom 
22q13 und codiert für ein 262 Aminosäuren langes Protein. Das orthologe Isoenzym PMM2 hingegen wird auf Chromosom 16p13 codiert und hat auf Aminosäure-Ebene eine 66 \%ige Homologie zu PMM1. Dies lässt die Vermutung zu, dass die beiden Phosphomannomutase-Gene PMM1 und PMM2 vor ca. 75 bis 110 Millionen Jahren aus einer Duplikation entstanden sind (Schollen et al., 1998). Bei dem Vergleich der jeweiligen orthologen Gene PMM1 und PMM2 des Menschen mit den Genen Pmm1 und Pmm2 der Maus findet sich mit $90 \%$ eine große Übereinstimmung der Aminosäuresequenz, die zudem in Exon-IntronÜbergängen im hohen Maße konserviert ist (Heykants et al., 2001).

Die Präsenz der zwei konservierten Isoenzyme spricht für eine signifikante Funktion beider, wobei die Rolle von PMM1 bislang nicht geklärt ist. Krankheitsauslösende Mutationen sind nicht bekannt und auch ein Knock-OutMausmodell für Pmm1 zeigte keinen pathologischen Phänotyp (Cromphout et al., 2006). In vitro besitzt PMM1 Phospomannomutase-Aktivität, diese kann jedoch die krankheitsauslösende reduzierte Aktivität der PMM2 bei CDG-la-Patienten in vivo nicht kompensieren. Untersuchungen der Expressionsmuster von Pmm1 in der Maus zeigten ein vermehrtes Vorkommen im Gehirn und neuroendokrinem Gewebe. Da auch Pmm2 in denselben Zellen exprimiert wird, kann die fehlende Kompensation nicht durch das Expressionsmuster erklärt werden (Cromphout et al., 2006).

Welche physiologische Rolle PMM1 in vivo spielt, soll in zukünftigen Studien durch Verpaarungen der Pmm1-Knock-Out-Maus und den oben genannten Mauslinien mit hypomorphen Pmm2-Allel geklärt werden. 


\section{$5 \quad$ Zusammenfassung und Ausblick}

CDG-la ist eine genetisch bedingte Stoffwechselstörung, die eine fehlerhafte Synthese von Glykoproteinen zur Folge hat. Ursache sind Mutationen in der genetischen Information für das Enzym Phosphomannomutase II (PMM2), welches innerhalb der Glykoproteinsynthesekette Mannose-6-Phosphat zu Mannose-1-Phosphat umsetzt. Infolge der verminderten Enzymaktivität von PMM2 bei CDG-la-Patienten und des damit verbundenen Mangels an Mannose-1Phosphat entstehen unvollständige und funktionsgestörte Glykoproteine.

Bei dieser Multisystemerkrankung leiden die Patienten unter körperlichen und geistigen Behinderungen, deren Ausmaß stark von der zugrundeliegenden Mutation und damit von der PMM2-Aktivität abhängt. Um weiterführende Untersuchungen im Bereich der Biochemie und Pathophysiologie sowie mögliche Therapieoptionen an höher entwickelten Lebewesen zu erforschen, soll ein Mausmodell für CDG-la generiert werden.

Inhalt dieser Arbeit ist die Generierung von zwei Gene-Targeting-Vektoren (GTV) und den entsprechenden transgenen embryonalen Maus-Stammzellen, welche jeweils die beiden häufigsten Mutationen R141H und F119L (R137H und F115L im Maus-Genom) tragen.

Zunächst wurde ein Teil des murinen Pmm2-Gens in einen pBlueScript-Vektor subkloniert. Mit gezielter in-vitro-Mutagenese erfolgte das Einbringen der jeweiligen Mutation. Als Selektionsmarker für beide GTV diente ein von zwei loxPSequenzen flankiertes Neomycin-Resistenzgen. Die beiden derart konstruierten GTV (GTV-F115L, GTV-R137H) wurden als linearisiertes Konstrukt durch Elektroporation in embryonale Mausstammzellen transferiert. Durch $G 418^{\circledR}$ Selektion, Southern-Blot-Analysen und DNA-Sequenzkontrollen wurden erfolgreich transfizierte transgene Klone nach der homologen Rekombination identifiziert. Zum Entfernen der noch inserierten Neo-Kassette wurde je ein Stammzell-Klon mit dem Genotyp F115L/WT und R137H/WT mit einem CreRekombinase-Gen enthaltenden Plasmid per Elektroporation transfiziert.

Nach Kontrolle der erfolgreichen Entfernung der Neo-Kassette mittels SouthernBlot und DNA-Sequenzanalyse wurde ein Klon mit der heterozygoten Mutation $\mathrm{R} 137 \mathrm{H}$ zur Mikroinjektion in Maus-Blastozysten verwendet. Die Blastozysten 
wurden pseudoschwangeren Foster-Weibchen eingesetzt, um Chimären zu erzeugen. Heterozygote Tiere, die aus Verpaarungen von chimären Männchen mit Weibchen des C57/BI06-Stammes entstammten, wurden zur Generierung homozygoter Stämme verwendet.

Wie zu erwarten, waren homozygote Mäuse mit dem Genotyp R137H/R137H nicht lebensfähig und verstarben schon intrauterin vor dem 6. Tag nach Befruchtung. Homozygote Tiere mit der sehr milden, synthetischen Mutation F118L (F122L beim Menschen; Silvaggi et al., 2006) zeigten trotz einer reduzierten PMMAktivität in kultivierten Embryonalfibroblasten der Maus von 38 \% im Vergleich zu Wildtyp-Mäusen keine Unterschiede im Phänotyp. Verpaarungen von heterozygoten WT/R137H-Mäusen mit einer hypomorphen F118L-Mauslinie zeigten ebenfalls eine embryonale Letalität, die zwischen Tag 9,5 und 10,5 nach Befruchtung lag. Besonders hervorzuheben ist die Erkenntnis, dass die beschriebene embryonale Letalität der compound-heterozygoten R137H/F118LMäuse durch eine pränatale und orale Mannose-Therapie überwindet werden kann und eine normale Entwicklung möglich ist (Schneider et al., 2011).

Meine praktischen Arbeiten zur Herstellung der beiden Gene-Targeting-Vektoren und der rekombinanten Stammzellen mit der Mutation F115L und R137H erfolgten in den Jahren 2001 bis 2004 in Göttingen. Die spätere Charakterisierung der verschiedenen Mauslinien einschließlich der Generierung der F118L-Mutation erfolgte nach dem Umzug der Arbeitsgruppe von Prof. Körner an das Zentrum für Kinder- und Jugendmedizin ab dem Jahr 2004 dann an der Universität Heidelberg. 


\section{$6 \quad$ Anhang}

\subsection{Abkürzungsverzeichnis}

A

Abb.

Amp

ATP

BMI

bp

BSA

bzw.

C

${ }^{\circ} \mathrm{C}$

ca.

CDG

cDNA

$\mathrm{Ci}$

CMP

cpm

Cre

CTP

d

$\mathrm{ddH}_{2} \mathrm{O}$

d.h.

DMEM

DMSO

DNA

dNTPs

Dol

E. coli

EDTA
Adenin

Abbildung

Ampicillin

Adenosintriphosphat

Body-Mass-Index

Basenpaare

Rinderserumalbumin

beziehungsweise

Cytosin

Grad Celsius

circa

Congenital Disorder(s) of Glycosylation

komplementäre DNA

Curie $\left(2,22 \times 10^{6}\right.$ counts per minute)

Cytidinmonophosphat

counts per minute

center of recombination (of phage P1)

Cytidintriphosphat

$\operatorname{Tag}(e)$

doppelt destilliertes Wasser

das heißt

Dulbecco's Modified Eagle Medium

Dimethylsulfoxid

Desoxyribonukleinsäure

Desoxyribonukleotide

Dolichol

Escherichia coli

Ethylendiamintetraessigsäure 


\begin{tabular}{|c|c|}
\hline ER & Endoplasmatisches Retikulum \\
\hline ES-Zellen & embryonale Stammzellen \\
\hline et al. & et alii (lat. und andere) \\
\hline $\mathrm{F}$ & Farad \\
\hline FKS & fötales Kälberserum \\
\hline Fuc & Fucose \\
\hline G & Guanin \\
\hline $\mathrm{G} 418^{\circledR}$ & Geneticin $® 418$ \\
\hline Gal & Galaktose \\
\hline GalNAc & $\mathrm{N}$-Acetylgalactosamin \\
\hline GDP & Guanosindiphosphat \\
\hline GIcNAc & $\mathrm{N}$-Acetylglukosamin \\
\hline GMP & Guanosinmonophosphat \\
\hline GTV & Gene-Targeting-Vektor \\
\hline $\mathrm{h}$ & Stunde(n) \\
\hline HEPES & $\mathrm{N}-2$-Hydroxyethylpiperazin-N'-2-Ethansulfonsäure \\
\hline IPTG & Isopropylthio- $\beta-D-G a l a k t o p y r a n o s i d$ \\
\hline I & Liter \\
\hline LB & Luria Broth \\
\hline LIF & leukemia inhibitor factor \\
\hline LLO & lipid linked oligosaccharides \\
\hline $\operatorname{loxP}$ & locus of crossing over (of phage P1) \\
\hline M & molar \\
\hline Man & Mannose \\
\hline MCS & multiple cloning site \\
\hline MEF & Maus-Embryonen-Fibroblasten \\
\hline MEM & Minimum Essential Medium \\
\hline $\min$ & Minute(n) \\
\hline MOPS & 3-(N-morpholino) propanesulfonic acid \\
\hline mRNA & messenger-Ribonukleinsäure \\
\hline NANA & Sialinsäure \\
\hline NEB & New England Biolab \\
\hline $\mathrm{Neo}$ & Neomycin \\
\hline OD & Optische Dichte \\
\hline
\end{tabular}




\begin{tabular}{|c|c|}
\hline OMIM & online Mendelian inheritance in man \\
\hline OST & Oligosaccharid-Transferase \\
\hline$P$ & Phosphat \\
\hline${ }^{32} \mathrm{P}$ & Phosphor 32 \\
\hline p.a. & pro analysi (lat. zur Analyse) \\
\hline PBS & Phosphat-gepufferte Kochsalzlösung \\
\hline pB-SK & pBlueScript-Vektor \\
\hline p.c. & post coitum \\
\hline PCR & Polymerase-Ketten-Reaktion \\
\hline PEG & Polyethylenglycol \\
\hline Pen/Strep & Penicillin/Streptomycin \\
\hline$P f u$ & Pyrococcus furiosus \\
\hline $\mathrm{pH}$ & negativer dekadischer Logarithmus der Protonenkonzentration \\
\hline PMM & Phosphomannomutase \\
\hline RNA & Ribonukleinsäure \\
\hline rpm & Umdrehungen pro Minute \\
\hline RT & Raumtemperatur \\
\hline s & Sekunde(n) \\
\hline SDS & Natriumdodecylsulfat \\
\hline SSC & standard saline citrate \\
\hline $\mathrm{T}$ & Thymin \\
\hline Tab. & Tabelle \\
\hline $\mathrm{T}_{\mathrm{ann}}$ & Annealing-Temperatur \\
\hline Taq & Thermophilus aquaticus \\
\hline TE & Tris-EDTA \\
\hline$T_{m}$ & Schmelztemperatur \\
\hline Tris & Tris(hydroxymethyl)-aminomethan \\
\hline$U$ & Unit \\
\hline$U$ & Uridin \\
\hline ü. N. & über Nacht \\
\hline UDP & Uridindiphosphat \\
\hline UMP & Uridinmonophosphat \\
\hline UV & ultraviolett \\
\hline $\mathrm{V}$ & Volt \\
\hline
\end{tabular}


Vol. Volumen

w/v Gewicht zu Volumen

WT Wildtyp

$x \mathrm{x} \quad \mathrm{x}$-fache Erdbeschleunigung

X-Gal 5-Brom-4-chlor-3-indolyl-b-D-galaktosid

z.B. zum Beispiel

Verwendete Vorsilben für Potenzen der Zahl Zehn:

$\begin{array}{lll}\mathrm{p} & \text { Piko } & \left(1 \times 10^{-12}\right) \\ \mathrm{n} & \text { Nano } & \left(1 \times 10^{-9}\right) \\ \mu & \text { Mikro } & \left(1 \times 10^{-6}\right) \\ \mathrm{m} & \text { Milli } & \left(1 \times 10^{-3}\right) \\ \mathrm{k} & \text { Kilo } & \left(1 \times 10^{3}\right) \\ \mathrm{M} & \text { Mega } & \left(1 \times 10^{6}\right)\end{array}$

Die chemischen Elemente wurden mit den üblichen Symbolen abgekürzt. Die Aminosäuren wurden entweder im Drei- oder im Ein-Buchstabencode angegeben. Bei einigen Begriffen wurden die englischen Fachtermini verwendet, da auch in der deutschsprachigen Fachliteratur eine Übersetzung dieser Begriffe unüblich und unzureichend ist.

\subsection{Primer-Sequenzen}

\begin{tabular}{l|l} 
Bezeichnung & Basensequenz \\
\hline floxneo-Sall-rein 1 & ATC CAA ATT AGT CGA CCT GCA GCC CCA \\
\hline floxneo-Sall-rein 2 & TGG GGC TGC AGG TCG ACT AAT TTG GAT \\
\hline Neo 1 & GAC CGC TTC CTC GTG CTT TAC \\
\hline pB-HindlII-raus 1 & GAA TTC GAT ATC AAG GTT ATC GAT ACC G \\
\hline pB-Hindlll-raus 2 & CGG TAT CGA TAA CCT TGA TAT CGA ATT C \\
\hline PMM2-F119L-A & CTT TCA TTG AAT TAC GAA ATG GCA TGT TG \\
\hline PMM2-F119L-B & CAA CAT GCC ATT TCG TAA TTC AAT GAA AG \\
\hline PMM2-R141H-A & CCA AGA AGA ACA CAT TGA ATT CTA CGA A
\end{tabular}




\begin{tabular}{l|l} 
PMM2-R141H-B & TTC GTA GAA TTC AAT GTG TTC TTC TTG G \\
\hline PMM2-Sall-rein 1 & CTA AAC TTA AGT CGA CGT TGC AGA CTG \\
\hline PMM2-Sall-rein 2 & CAG TCT GCA ACG TCG ACT TAA GTT TAG \\
\hline PMM2-Test-A & GTA GTA CTG TGT GGC TCA AAG C \\
\hline PMM2-Test D & CCA TGA TGT CAC TTA CTC ATG C \\
\hline TL24 & GGG ACT TTG TTC CGC TAA CAG \\
\hline TL25 & GTT GCC CAT CAC TTG GGG TG \\
\hline TL27 & GTG CCT CAA GGT GTA ACC CC \\
\hline TL42 & CAG GAT GTG TCA CGT TGG CTG ACC AC \\
\hline TL44 & CGG GTG CTG CTG GAG TGA CAG GC \\
\hline TL61 & CTG TCC TGG GTT ATG ACT TG \\
\hline 4-Kb-BamHI-raus 1 & CAC CTT TTT GTA GGA TGC ACT AG \\
\hline 4-Kb-BamHI-raus 2 & CTA GTG CAT CCT ACA AAA AGG TG \\
\hline 4-Kb-rev 1 & CAC ACA ACC GGG ACC CAA GG \\
\hline 4-Kb rev 2 & GCT AAG TAG CTG GTT CTA AAG C
\end{tabular}




\section{$7 \quad$ Literaturverzeichnis}

Aebi M, Helenius A, Schenk B, Barone R, Fiumara A, Berger EG, Hennet T, Imbach T, Stutz A, Bjursell C (1999): Carbohydrate-deficient glycoprotein syndromes become congenital disorders of glycosylation: an updated nomenclature for CDG. First International Workshop on CDGS. Glycoconj J 11:669-71:

Alwine JC, Kemp DJ, Stark GR (1977): Method for detection of specific RNAs in agarose gels by transfer to diazobenzyloxymethyl-paper and hybridization with DNA probes. Proc Natl Acad Sci 74: 5350-5354.

\section{Anand M, Rush JS, Ray S, Doucey MA, Weik J, Ware FE, Hofsteenge J,} Waechter CJ, Lehrman MA (2001): Requirement of the Lec35 gene for all known classes of monosaccharide-P-dolichol-dependent glycosyltransferase reactions in mammals. Mol Biol Cell 2: 487-501.

Andréasson S, Blennow G, Ehinger B, Strömland K (1991): Full-field electroretinograms in patients with the carbohydrate-deficient glycoprotein syndrome. Am J Ophthalmol 112: 83-86.

Aratani Y, Okazaki R, Koyama H (1992): End extension repair of introduced targeting vectors mediated by homologous recombination in mammalian cells. Nucleic Acids Res 20: 4795-4801.

Argos P, Landy A, Abremski K, Egan JB, Haggard-Ljungquist E, Hoess RH, Kahn ML, Kalionis B, Narayana SV, Pierson LS $3^{\text {rd }}$ (1986): The integrase family of site-specific recombinases: regional similarities and global diversity. EMBO J $\underline{5}: 433-440$.

Austin S, Ziese M, Sternberg N (1981): A novel role for site-specific recombination in maintenance of bacterial replicons. Cell 25: 729-736. 
Bjursell C, Erlandson A, Nordling M, Nilsson S, Wahlstrom J, Stibler H, Kristiansson B, Martinsson T (2000): PMM2 mutation spectrum, including 10 novel mutations, in a large CDG type $1 \mathrm{~A}$ family material with a focus on Scandinavian families. Hum Mutat 16: 395-400.

Bradley A, Evans M, Kaufman MH, Robertson E (1984): Formation of germ-line chimaeras from embryo-derived teratocarcinoma cell lines. Nature $\underline{309}$ : 255-256.

Burda P, Borsig L, de Rijk-van Andel J, Wevers R, Jaeken J, Carchon H, Berger EG, Aebi M (1998): A novel carbohydrate-deficient glycoprotein syndrome characterized by a deficiency in glucosylation of the dolichollinked oligosaccharide. J Clin Invest 102: 647-652.

Cantagrel V, Lefeber DJ, Ng BG, Guan Z, Silhavy JL, Bielas SL, Lehle L, Hombauer H, Adamowicz M, Swiezewska E (2010): SRD5A3 is required for the conversion of polyprenol to dolichol, essential for $\mathrm{N}$-linked protein glycosylation. Cell 142: 203-217.

Capecchi MR (1989): The new mouse genetics: altering the genome by gene targeting. Trends Genet $\underline{5}$ : 70-76.

Chantret I, Dupre T, Delenda C, Bucher S, Dancourt J, Barnier A, Charollais A, Heron D, Bader-Meunier B, Danos $O$ (2002): Congenital disorders of glycosylation type $\mathrm{lg}$ is defined by a deficiency in dolichyl-Pmannose:Man7GIcNAc2-PP-dolichyl mannosyltransferase. J Biol Chem 277: 25815-25822.

Chantret I, Dancourt J, Dupre T, Delenda C, Bucher S, Vuillaumier-Barrot S, Ogier De Baulny H, Peletan C, Danos O, Seta N (2003): A deficiency in dolichyl-P-glucose:Glc1Man9GIcNAc2-PP-dolichyl-alpha3glucosyltransferase defines a new subtype of congenital disorders of glycosylation. J Biol Chem 278: 9962-9971. 
Clayton PT, Winchester BG, Keir G (1992): Hypertrophic obstructive cardiomyopathy in a neonate with the carbohydrate-deficient glycoprotein syndrome. J Inherit Metab Dis 15: 857-861.

Cromphout K, Vleugels W, Heykants L, Schollen E, Keldermans L, Sciot R, D'Hooge R, De Deyn PP, von Figura K, Hartmann D (2006): The normal phenotype of Pmm1-deficient mice suggests that Pmm1 is not essential for normal mouse development. Mol Cell Biol 15: 5621-35.

Damen G, de Klerk H, Huijmans J, den Hollander J, Sinaasappel M. (2004): Gastrointestinal and other clinical manifestations in 17 children with congenital disorders of glycosylation type la, lb, and Ic. $J$ Pediatr Gastroenterol Nutr 38: 282-287.

de Lonlay P, Seta N, Barrot S, Chabrol B, Drouin V, Gabriel BM, Journel H, Kretz M, Laurent J, Le Merrer M (2001): A broad spectrum of clinical presentations in congenital disorders of glycosylation I: a series of 26 cases. J Med Genet 38: 14-19.

Deng C, Capecchi MR (1992): Reexamination of gene targeting frequency as a function of the extent of homology between the targeting vector and the target locus. Mol Cell Biol 12: 3365-3371.

de Praeter CM, Gerwig GJ, Bause E, Nuytinck LK, Vliegenthart JF, Breuer W, Kamerling JP, Espeel MF, Martin JJ, De Paepe AM (2000): A novel disorder caused by defective biosynthesis of $\mathrm{N}$-linked oligosaccharides due to glucosidase I deficiency. Am J Hum Genet $\underline{66}$ : 1744-1756.

Eklund EA, Merbouh N, Ichikawa M, Nishikawa A, Clima JM, Dorman JA, Norberg T, Freeze H (2005): Hydrophobic Man-1-P derivatives correct abnormal glycosylation in Type I congenital disorder of glycosylation fibroblasts. Glycobiology 15: 1084-1093. 
Erlandson A, Bjursell C, Stibler H, Kristiansson B, Wahlstrom J, Martinsson T (2001): Scandinavian CDG-la patients: genotype/phenotype correlation and geographic origin of founder mutations. Hum Genet 108: 359-367.

Evans MJ, Kaufman MH (1981): Establishment in culture of pluripotential cells from mouse embryos. Nature 292: 154-156.

Foulquier F, Vasile E, Schollen E, Callewaert N, Raemaekers T, Quelhas D, Jaeken J, Mills P, Winchester B, Krieger M, Annaert W, Matthijs G (2006): Conserved oligomeric Golgi complex subunit 1 deficiency reveals a previously uncharacterized congenital disorder of glycosylation type II. Proc Nat Acad Sci 103: 3764-3769.

Foulquier F, Ungar D, Reynders E, Zeevaert R, Mills P, Garcia-Silva M T, Briones P, Winchester B, Morelle W, Krieger M (2007): A new inborn error of glycosylation due to a Cog8 deficiency reveals a critical role for the Cog1-Cog8 interaction in COG complex formation. Hum Molec Genet 16 : 717-730.

Frank C G, Grubenmann C E, Eyaid W, Berger E G, Aebi M, Hennet T (2004): Identification and functional analysis of a defect in the human ALG9 gene: definition of congenital disorder of glycosylation type IL. Am J Hum Genet 75: 146-150.

Freeze H H (1998): Disorders in protein glycosylation and potential therapy: tip of an iceberg? J Pediatrics 133: 593-600.

Freeze H H (2001): Congenital disorders of glycosylation and the pediatric liver. Semin Liver Dis 21:501-15

Freeze H H (2006): Genetic defects in the human glycome. Nat Rev Genet 7: $537-$ 51. 
Fukuda M (1996): Possible roles of tumor-associated carbohydrate antigens. Cancer Res 56: 2237-2244.

Gabius HJ (1987): Vertebrate lectins and their possible role in fertilization, development and tumor biology. In Vivo 1: 75-83.

Grubenmann CE, Frank CG, Kjaergaard S, Berger EG, Aebi M, Hennet T (2002): ALG12 mannosyltransferase defect in congenital disorder of glycosylation type Ig. Hum Mol Genet 19: 2331-9.

Haeuptle M A, Pujol F M, Neupert C, Winchester B, Kastaniotis A J, Aebi M, Hennet T (2008): Human RFT1 deficiency leads to a disorder of $\mathrm{N}$-linked glycosylation. Am J Hum Genet 82: 600-606.

Hansske B, Thiel C, Lübke T, Hasilik M, Honing S, Peters V, Heidemann PH, Hoffmann GF, Berger EG, von Figura K (2002): Deficiency of UDPgalactose: $\mathrm{N}$-acetylglucosamine beta-1,4-galactosyltransferase I causes the congenital disorder of glycosylation type Ild. J Clin Invest 109: 725-733.

Hardré R, Khaled A, Willemetz A, Dupré T, Moore S, Gravier-Pelletier C, Le Merrer $Y$ (2007): Mono, di and tri-mannopyranosyl phosphates as mannose1-phosphate prodrugs for potential CDG-la therapy. Bioorg Med Chem Lett 17: $152-5$.

Hasty P, Rivera-Perez J, Bradley A (1992): The role and fate of DNA ends for homologous recombination in embryonic stem cells. Mol Cell Biol 12: 24642474.

Helenius J, Ng DTW, Marolda CL, Walter P, Valvano MA, Aebi M (2002): Translocation of lipid-linked oligosaccharides across the ER membrane requires Rft1 protein. Nature $\underline{415}$ : 447-451.

Heykants L, Schollen E, Grunewald S, Matthijs G (2001): Identification and localization of two mouse phosphomannomutase genes, Pmm1 and Pmm2. Gene 270: 53-59. 
Hirschberg CB, Robbins PW, Abeijon C (1998): Transporters of nucleotide sugars, ATP, and nucletide sulfate in the endoplasmatic reticulum and Golgi apparatus. Annu Rev Biochem 67: 49-69.

Hoess RH, Ziese M, Sternberg N (1982): P1 site-specific recombination: nucleotide sequence of the recombining sites. Proc Natl Acad Sci U S A $\underline{79}$ : 3398-3402.

Hogan B, Beddington R, Constantini F, Lacy E: Manipulating the Mouse Embryo. A Laboratory Manual. Second Edition. Cold Spring Laboratory Press, New York 1994.

Imbach T, Burda P, Kuhnert P, Wevers RA, Aebi M, Berger EG, Hennet T (1999): A mutation in the human ortholog of the Saccharomyces cerevisiae ALG6 gene causes carbohydrate-deficient glycoprotein syndrome type-lc. Proc Natl Acad Sci USA 96: 6982-6987.

Imbach T, Schenk B, Schollen E, Burda P, Stutz A, Grunewald S, Bailie NM, King MD, Jaeken J, Matthijs G (2000): Deficiency of dolichol-phosphatemannose synthase-1 causes congenital disorder of glycosylation type le. $J$ Clin Invest 105: 233-239.

Jaeken J, Carchon H (1993): The carbohydrate-deficient glycoprotein syndromes: an overview. J Inherit Metab Dis 16: 813-820.

Jaeken J, Carchon H (2004): Congenital disorders of glycosylation: a booming chapter of pediatrics. Curr Opin Pediatr 16: 434-9.

Jaeken J, Stibler H: A newly recognized inherited neurological disease with carbohydrate-deficient secretory glycoproteins. In: Genetics of Neuropsychiatric Diseases. Wenner-Gren International Symposium Series, L. Wetterberg, Vol. 51, Macmillian Press, London, 1989, 69-80. 
Jaeken J, Vanderschueren-Lodeweyckx M, Casaer P, Snoeck L, Corbeel L, Eggermont E, Eeckels R (1980): Familial psychomotor retardation with markedly fluctuating serum prolactin, FSH and GH levels, partial TBG deficiency, increased serum arylsulphatase $A$ and increased CSF protein: a new syndrom? Pediatr Res 14: 179.

Jaeken J, van Eijk H.G, van der Heul C, Corbeel L, Eeckels R, Eggermont E (1984): Sialic acid-deficient serum and cerebrospinal fluid transferrin in an newly recognized genetic syndrom. Clin Chim Acta 144: 245-247.

Jaeken J, Eggermont E, Stibler H (1987): An apparent homozygous X-linked disorder with carbohydrate-deficient serum glycoproteins. Lancet 1987,2: 1398.

Jaeken J, Schachter H, Carchon H, De Cock P, Coddeville B, Spik G (1994): Carbohydrate deficient glycoprotein syndrome type II: a deficiency in Golgi localised N-acetyl-glucosaminyltransferase II. Arch Dis Child 1ㅡ: 123-127.

Joyner AL: Gene Targeting. A Practical Approach. IRL Press at Oxford University Press, New York 1993.

Kean EL (1991): Sialic acid activation. Glykobiology 1: 441-447.

Kim S, Westphal V, Srikrishna G, Mehta DP, Peterson S, Filiano J, Karnes PS, Patterson MC, Freeze HH (2000): Dolichol phosphate mannose synthase (DPM1) mutations define congenital disorder of glycosylation le (CDG-le). J Clin Invest 105: 191-198.

Kitamura K, Suganuma N, Takata K, Matsuyama K, Goto J, Furuhashi M, Kanayama N (2003): Changes in oligosaccharide expression on plasma membrane of the mouse oocyte during fertilisation and early cleavage. Zygote 11: 183-9. 
Kjaergaard S, Skovby F, Schwartz M (1998): Absence of homozygosity for predominant mutations in PMM2 in Danish patients with carbohydratedeficient glycoprotein syndrome type 1. Eur J Hum Genet $\underline{6}$ : 331-336.

Kjaergaard S, Schwartz M, Skovby F (2001): Congenital disorder of glykosylation type la (CDG-la): phenotypic spectrum of the R141H/F119L genotyp. Arch Dis Child 85: 236-239.

Kjaergaard S, Müller J, Skovby F (2002): Prepubertal growth in congenital disorder of glycosylation type la (CDG-la). Arch Dis Child 87: 324-327.

Körner C, Lehle L, von Figura K (1998): Carbohydrate-deficient glycoprotein syndrome type 1: correction of the glycosylation defect by deprivation of glucose or supplementation of mannose. Glycoconj J 15: 499-505.

Körner C, Knauer R, Stephani U, Marquardt T, Lehle L, von Figura K (1999): Carbohydrate deficient glycoprotein syndrome type IV: deficiency of dolichyl-P-Man:Man(5)GIcNAc(2)-PP-dolichyl mannosyltransferase. EMBO J 18: 6816-6822.

Kornfeld R, Kornfeld S (1985): Assembly of asparagine-linked oligosaccharides. Annu Rev Biochem 54: 631-664.

Kranz C, Denecke J, Lehrman MA, Ray S, Kienz P, Kreissel G, Sagi D, PeterKatalinic J, Freeze HH, Schmid T (2001): A mutation in the human MPDU1 gene causes congenital disorder of glycosylation type If (CDG-If). $J$ Clin Invest 108: 1613-1619.

Kranz C, Denecke J, Lehle L, Sohlbach K, Jeske S, Meinhardt F, Rossi R, Gudowius S, Marquardt T. (2004): Congenital disorder of glycosylation type Ik (CDG-Ik): a defect of mannosyltransferase I. Am J Hum Genet $\underline{74}$ : 545-551. 
Kranz C, Jungeblut C, Denecke J, Erlekotte A, Sohlbach C, Debus V, Kehl H G, Harms E, Reith A, Reichel S, Grobe H, Hammersen G, Schwarzer U, Marquardt T (2007a): A defect in dolichol phosphate biosynthesis causes a new inherited disorder with death in early infancy. Am J Hum Genet $\underline{80}$ : 433-440.

Kranz C, Ng B G, Sun L, Sharma V, Eklund E A, Miura Y, Ungar D, Lupashin V, Winkel R D, Cipollo J F (2007b): COG8 deficiency causes new congenital disorder of glycosylation type Ilh. Hum Molec Genet 16: 731-741.

Krasnewich D, O'brien K, Sparks S (2007): Clinical features in adults with congenital disorders of glycosylation type la (CDG-la). Am J Med Genet C Semin Med Genet 145C: 302-6.

Kristiansson B, Andersson M, Tonnby B, Hagberg B (1989): Disialotransferrin developmental deficiency syndrome. Arch Dis Child 64: 71-76.

Lefeber D J, Schonberger J, Morava E, Guillard M, Huyben K M, Verrijp J, Grafakou O, Grunewald S (2009): Deficiency of Dol-P-Man synthase subunit DPM3 bridges the congenital disorders of glycosylation with the dystroglycanopathies. Am J Hum Genet 85: 76-86.

Lehrach H, Frischauf AM: EMBL Lab-Manual. EMBL, Heidelberg 1982.

Lennarz W (1993): Glycoprotein Synthesis and embryonic development. Crit Rev Biochem 14: 257-272.

Lübbehusen J, Thiel C, Rind N, Ungar D, Prinsen B, de Koning TJ, van Hasselt PM, Körner C (2010): Fatal outcome due to deficiency of subunit 6 of the conserved oligomeric Golgi complex leading to a new type of congenital disorders of glycosylation. Hum Mol Genet 19: 3623-3633.

Lübke T, Marquardt T, von Figura K, Körner C (1999): A new type of carbohydrate-deficient glycoprotein syndrome due to a decreased import of GDP-fucose into the golgi. J Biol Chem 274: 25986-25989. 
Lübke T, Marquardt T, Etzioni A, Hartmann E, von Figura K, Körner C (2001): Complementation cloning identifies CDG-Ilc, a new type of congenital disorders of glycosylation, as a GDP-fucose transporter deficiency. Nat Genet 28: 73-76.

Lühn K, Wild MK, Eckhardt M, Gerardy-Schahn R, Vestweber D (2001): The gene defective in leukocyte adhesion deficiency II encodes a putative GDPfucose transporter. Nat Genet 28: 69-72.

MacGillivray RTA, Mendez E, Shewale JG, Sinha SK, Lineback-Zins J, Brew K (1983): The primary structure of human serum transferrin. J Biol Chem 258: 3543-3553.

Mamo S, Kobolak J, Borbíró I, Bíró T, Bock I, Dinnyes A (2010): Gene targeting and Calcium handling efficiencies in mouse embryonic stem cell lines. World J Stem Cells 2: 127-140.

Mansouri A: Gene Targeting by Homologous Recombination in Embryonic Stem Cells. In: Cell Biology. A Laboratory Handbook; hrsg. v. Celis JE. Second Edition. Vol. 3. Academic Press, San Diego 1998, 478-497.

Martin GR (1981): Isolation of a pluripotent cell line from early mouse embryos cultured in medium conditioned by teratocarcinoma stem cells. Proc Natl Acad Sci U S A 78: 7634-7638.

\section{Martinez-Duncker I, Dupre T, Piller V, Piller F, Candelier J-J, Trichet C} Tchernia G, Oriol, R, Mollicone R (2005): Genetic complementation reveals a novel human congenital disorder of glycosylation of type II, due to inactivation of the Golgi CMP-sialic acid transporter. Blood 105: 2671-2676. 
Matthijs G, Schollen E, Pardon E, Veiga-Da-Cunha M, Jaeken J, Cassiman JJ, Van Schaftingen E (1997a): Mutations in PMM2, a phosphomannomutase gene on chromosome 16p13, in carbohydratedeficient glycoprotein type I syndrome (Jaeken syndrome). Nat Genet $\underline{16}$ : 88-92.

Matthijs G, Schollen E, Pirard M, Budarf ML, Van Schaftingen E, Cassiman JJ (1997b): PMM (PMM1), the human homologue of SEC53 or yeast phosphomannomutase, is localized on chromosome 22q13. Genomics 40: 41-47.

Matthijs G, Schollen E, Van Schaftingen E, Cassiman JJ, Jaeken J (1998): Lack of homozygotes for the most frequent disease allele in carbohydrate-deficient glycoprotein syndrome type 1A. Am J Hum Genet 62: $542-550$.

Matthijs G, Schollen E, Bjursell C, Erlandson A, Freeze H, Imtiaz F, Kjaergaard S, Martinsson T, Schwartz M, Seta N (2000): Mutations in PMM2 that cause congenital disorders of glycosylation, type la (CDG-la). Hum Mutat 16: 386-394.

Mayatepek E, Kohlmüller D (1998): Mannose supplementation in carbohydratedeficient glycoprotein syndrom type I and phosphomannomutase deficiency. Eur J Pediatr 157: 605-606.

Mayatepek E, Schröder M, Kohlmüller D, Bieger WP, Nützenadel W (1997): Continous mannose infusion in carbohydrate-deficient glycoprotein syndrom type I. Acta Paediatr 86: 1138-1140.

McPherson MJ, Quirke P, Tayler GR: PCR I: A Laboratory Approach. IRL Press at Oxford University Press, London 1991. 
Meinzinger S: Biochemische und molekularbiologische Studien zur Funktionsanalyse der UDP-Galaktose: Ceramid Galaktosyltransferase. Diss. rer. nat. Köln 2004.

Müller W, Kühn R, Rajewsky K (1991): Major histocompatibility complex class II hyperexpression on B cells in interleukin 4-transgenic mice does not lead to B cell proliferation and hypergammaglobulinemia. Eur J Immunol 21: 921925.

\section{Münster AK, Eckardt M, Potvin B, Mühlenhoff M, Stanley P, Gerardy-Schahn} R (1998): Mammalian cytidine 5'-monophosphate $\mathrm{N}$-acetylneuraminic acid synthetase: a nuclear protein with evolutionarily conserved structural motifs. Proc Natl Acad Sci USA 95: 9140-9145.

Muus U, Kranz C, Marquardt T, Meier C (2004): cycloSaligenyl-mannose-1monophosphates as a New Strategy in CDG-la Therapy: Hydrolysis, Mechanistic Insights and Biological Activity. Eur J Org Chem: 1228-1235.

Niehues R, Hasilik M, Alton G, Körner C, Schiebe-Sukumar M, Koch HG, Zimmer KP, Wu R, Harms E, Reiter K (1998): Carbohydrate-deficient glycoprotein syndrome type lb. Phosphomannose isomerase deficiency and mannose therapy. J Clin Invest 101: 1414-1420.

Orr-Weaver TL, Szostak JW (1983): Yeast recombination: the association between double-strand gap repair and crossing-over. Proc Natl Acad Sci U S A 80: 4417-4421.

Paesold-Burda P, Maag C, Troxler H, Foulquier F, Kleinert P, Schnabel S, BaumgartnerM, Hennet T (2009): Deficiency in COG5 causes a moderate form of congenital disorders of glycosylation. Hum Mol Genet 18: 43504356. 
Panneerselvam K, Freeze HH (1996): Mannose corrects altered N-glycosylation in carbohydrate-deficient glycoprotein syndrome fibroblasts. J Clin Invest 97: 1478-1487.

Peters V, Penzien JM, Reiter G, Körner C, Hackler R, Assmann B, Fang J, Schaefer JR, Hoffmann GF, Heidemann PH (2002): Congenital disorder of glycosylation IId (CDG-IId) -- a new entity: clinical presentation with Dandy-Walker malformation and myopathy. Neuropediatrics 33: 27-32.

Petersen MB, Brostrom K, Stibler H, Skovby F (1993): Early manifestations of the carbohydrate-deficient glycoprotein syndrome. J Pediatr 122: 66-70.

Pirard M, Matthijs G, Heykants L, Schollen E, Grunewald S, Jaeken J, van Schaftingen E (1999): Effect of mutations found in carbohydrate-deficient glycoprotein syndrome type IA on the activity of phosphomannomutase 2 . FEBS Lett 452: 319-322.

Qiagen Handbuch: HotStar-Taq-PCR, Qiagen, Hilden 1999.

Qiagen Handbuch: The QIAexpressionist. Protokol 2: Preparation of competent E. coli. Qiagen, Hilden 2001.

QIAprep Midiprep Handbuch, Qiagen, Hilden 1999.

QIAprep Miniprep Handbuch, Qiagen, Hilden 1999.

QIAquick Gel Extraction Kit, Handbuch, Qiagen, Hilden 1999.

QuikChange $^{\mathrm{TM}}$ Site-Directed Mutagenesis Kit Instruction Manual, Stratagene, La Jolla, Californien 1996.

Ramdas J, Mythili E, Muniyappa K (1991): Nucleosomes on linear duplex DNA allow homologous pairing but prevent strand exchange promoted by RecA protein. Proc Natl Acad Sci U S A 88: 1344-1348. 
Reynders E, Foulquier F, Teles EL, Quelhas D, Morelle W, Rabouille C, Annaert W, Matthijs G (2009): Golgi function and dysfunction in the first COG4-deficient CDG type II patient. Hum Mol Genet 18: 3244-3256.

Rind N, Schmeiser V, Thiel C, Absmanner B, Lübbehusen J, Hocks J, Apeshiotis N, Wilichowski E, Lehle L, Körner C (2010): A severe human metabolic disease caused by deficiency of the endoplasmatic mannosyltransferase hALG11 leads to congenital disorder of glycosylationIp. Hum Mol Genet 19,1413-24.

Robertson EJ: Teratocarcinomas and Embyonic Stem Cells. IRL Press, Oxford, 1987.

Rush JS, Panneerselvam K, Waechter CJ, Freeze HH (2000): Mannose supplementation corrects GDP-mannose deficiency in cultured fibroblasts from some patients with Congenital Disorders of Glycosylation (CDG). Glycobiology 10: 829-835.

Saiki RK, Bugawan TL, Horn GT, Mullis KB, Erlich HA (1986): Analysis of enzymatically amplified beta-globin and HLA-DQ alpha DNA with allelespecific oligonucleotide probes. Nature $\underline{324}$ : 163-166.

Saiki RK, Gelfand DH, Stoffel S, Scharf SJ, Higuchi R, Horn GT, Mullis KB, Erlich HA (1988): Primer-directed enzymatic amplification of DNA with a thermostable DNA polymerase. Science 239: 487-491.

Sambrook J, Frritsch E F, Maniatis T: Molecular Cloning, a laboratory manual, second edition. Cold Spring Harbor Laboratory Press, New York 1989.

Sargent RG, Wilson JH (1998): Recombination and gene targeting in mammalian cells. Curr Res Mol Ther 1: 584-592.

Schenk B, Imbach T, Frank CG, Grubenmann CE, Raymond GV, Hurvitz H, Korn-Lubetzki I, Revel-Vik S, Raas-Rotschild A, Luder AS (2001): 
MPDU1 mutations underlie a novel human congenital disorder of glycosylation, designated type If. J Clin Invest 108: 1687-1695.

Schneider A, Thiel C, Rindermann J, De Rossi C, Popovici D, Hoffmann GF, Gröne H-J, Körner C (2011): Successful prenatal mannose treatment for congenital disorder of glycosylation-la in mice. Nat Med 18: 71-73.

Schollen E, Pardon E, Heykants L, Renard J, Doggett NA, Callen DF, Cassiman JJ, Matthijs G (1998): Comparative analysis of the phosphomannomutase genes PMM1, PMM2 and PMM2psi: the sequence variation in the processed pseudogene is a reflection of the mutations found in the functional gene. Hum Mol Genet $\underline{7}:$ 157-164.

Schollen E, Kjaergaard S, Legius E, Schwartz M, Matthijs G (2000): Lack of Hardy-Weinberg equilibrium for the most prevalent PMM2 mutation in CDGla (congenital disorders of glycosylation type la). Eur J Hum Genet $\underline{8}$ : 367371.

Schollen E, Frank CG, Keldermans L, Reyntjens R, Grubenmann CE, Clayton PT, Winchester BG, Smeitink J, Wevers RA, Aebi M. (2004): Clinical and molecular features of three patients with congenital disorders of glycosylation type Ih (CDG-Ih) (ALG8 deficiency). J Med Genet 7: 550-6.

Schultz RM (2002): The molecular foundations of the maternal to zygotic transition in the preimplantation embryo. Hum Reprod Update $\underline{8}$ : 323-31.

Schwarz M, Thiel C, Lubbehusen J, Dorland B, de Koning T, von Figura K, Lehle L, Körner C (2004): Deficiency of GDP-Man:GlcNAc2-PP-dolichol mannosyltransferase causes congenital disorder of glycosylation type lk. Am J Hum Genet 74: 472-481.

Silvaggi NR, Zhang C, Lu Z, Dai J, Dunaway-Mariano D, Allen KN (2006): The X-ray Crystal Structures of Human -Phosphomannomutase 1 Reveal the 
Structural Basis of Congenital Disorder of Glycosylation Type 1a. J Biol Chem 281: 14918-14926.

Smithies O, Gregg RG, Boggs SS, Koralewski MA, Kucherlapati RS (1985): Insertion of DNA sequences into the human chromosomal beta-globin locus by homologous recombination. Nature 317: 230-234.

Southern EM (1975): Detection of specific sequences among DNA fragments separated by gel electrophoresis. J Mol Biol 98: 503-517.

Spik G, Bayard B, Fournet B, Strecker G, Bouquelet S, Montreuil J (1975): FEBS Lett. 50, 296-299.

Spiro RG (1973): Glykoproteins. Adv Protein Chem 27: 349-467.

Sternberg N, Hamilton D (1981): Bacteriophage P1 site-specific recombination. I. Recombination between loxP sites. J Mol Biol 150: 467-486.

Tan J, Dunn J, Jaeken J, Schachter H (1996): Mutations in the MGAT2 gene controlling complex $\mathrm{N}$-glycan synthesis cause carbohydrate-deficient glycoprotein syndrome type II, an autosomal recessive disease with defective brain development. Am J Hum Genet 59: 810-817.

Tatu U, Helenius A (1997): Interaktions between newly synthesized glycoproteins, calnexin and a network of resident chaperones in the endoplasmatic reticulum. J Cell Biol 136: 555-565.

te Riele H, Maandag ER, Berns A (1992): Highly efficient gene targeting in embryonic stem cells through homologous recombination with isogenic DNA constructs. Proc Natl Acad Sci U S A 89: 5128-5132.

Thiel C, Schwarz M, Hasilik M, Grieben U, Hanefeld F, Lehle L, Von Figura K, Körner C (2002): Deficiency of dolichyl-P-Man:Man7GIcNAc2-PP-dolichyl 
mannosyltransferase causes congenital disorder of glycosylation type Ig. Biochem J 367: 195-201.

Thiel C, Schwarz M, Peng J, Grzmil M, Hasilik M, Braulke T, Kohlschutter A, Von Figura K, Lehle L, Körner C (2003): A new type of congenital disorders of glycosylation (CDG-li) provides new insights into the early steps of dolichol-linked oligosaccharide biosynthesis. J Biol Chem 278: 22498-22505.

Thiel C, Lubke T, Matthijs G, von Figura K, Korner C (2006): Targeted disruption of the mouse phosphomannomutase 2 gene causes early embryonic lethality. Mol Cell Biol 26: 5615-20.

Thomas KR, Capecchi MR (1987): Site-directed mutagenesis by gene targeting in mouse embryo-derived stem cells. Cell 51: 503-512.

Valancius V, Smithies O (1991): Double-strand gap repair in a mammalian gene targeting reaction. Mol Cell Biol 11: 4389-4397.

Van Geet C, Jaeken J. (1993): A unique pattern of coagulation abnormalities in carbohydrate-deficient glycoprotein syndrome. Pediatr Res 33: 540-1.

van Schaftingen E, Jaeken J (1995): Phosphomannomutase deficiency is a cause of carbohydrate-deficient glycoprotein syndrome type I. FEBS Lett 377: 318-320.

Varki A (1993): Biological roles of oligosaccharides: all of the theories are correct. Glycobiologie $\underline{3}:$ 97-130.

Vasquez KM, Marburger K, Intody Z, Wilson JH (2001): Manipulating the mammalian genome by homologous recombination. Proc Natl Acad Sci $\underline{98}$ : 8403-8410. 
Wada Y, Nishikawa A, Okamoto N, Inui K, Tsukamoto H, Okada S, Taniguchi N (1992): Structure of serum transferrin in carbohydrate-deficient glycoprotein syndrome. Biochem Biophys Res Commun 189: 832-836.

Wada Y, Gu J, Okamoto N, Inui K (1994): Diagnosis of carbohydrate-deficient glycoprotein syndrome by matrix-assisted laser desorption time-of-flight mass spectrometry. Biol Mass Spectrom 23: 108-109.

Weinstein M, Schollen E, Matthijs G, Neupert C, Hennet T, Grubenmann C E, Frank C G, Aebi M, Clarke J T R, Griffiths A (2005): CDG-IL: an infant with a novel mutation in the ALG9 gene and additional phenotypic features. Am J Med Genet 136A: 194-197.

Willig T-N, Breton-Gorius J, Elbim C, Mignotte V, Kaplan C, Mollicone R, Pasquier C, Filipe A, Mielot F, Cartron J-P (2001):

Macrothrombocytopenia with abnormal demarcation membranes in megakaryocytes and neutropenia with a complete lack of sialyl-Lewis-X antigen in leukocytes--a new syndrome? Blood 97: 826-828.

Wong EA and Capecchi MR (1986): Analysis of homologous recombination in cultured mammalian cells in transient expression and stable transformation assays. Somat Cell Mol Genet 12: 63-72.

Wu X, Rush JS, Karaoglu D, Krasnewich D, Lubinsky MS, Waechter CJ, Gilmore R, Freeze HH (2003): Deficiency of UDP-GlcNAc:dolichol phosphate $\mathrm{N}$-acetylglucosamine-1 phosphate transferase (DPAGT1) causes a novel congenital disorder of glycosylation type lj. Hum Mutat $\underline{22}$ : 144-150.

Wu X, Steet RA, Bohorov O, Bakker J, Newell J, Krieger M, Spaapen L, Kornfeld S, Freeze HH (2004): Mutation of the COG complex subunit gene COG7 causes a lethal congenital disorder. Nat Med 10: 518-523. 
Yamashita K, Ideo H, Ohkura T, Fukushima K, Yuasa I, Ohno K, Takeshita K (1993): Sugar chains of serum transferrin from patients with carbohydrate deficient glycoprotein syndrome. Evidence of asparagine-N-linked oligosaccharide transfer deficiency. J Biol Chem 268: 5783-5789. 